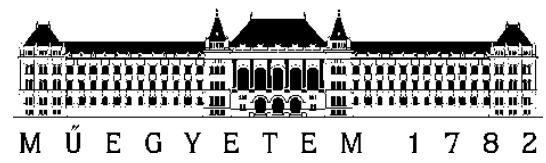

Budapest University of Technology and Economics

Faculty of Electrical Engineering and Informatics

Department of Electrical Power Engineering

Seerin Ahmad

\title{
IMPACT ASSESSMENT OF ELECTRIC CAR CHARGING ON LV GRIDS
}

\author{
SUPERVISOR \\ Dr. Farkas Csaba
}




\title{
MSC THESIS TASK DESCRIPTION
}

\author{
Seerin Ahmad
}

Candidate for MSc degree in Electrical Engineering

\section{Impact assessment of electric car charging on LV grids}

In the future, electric vehicles seem to be the key for sustainable transportation. Indeed, among the many technologies available, the electrification of transportation has the widest scope both economically and in terms of environmental friendliness. Although the number of electric cars is still very low, DSOs (and even TSOs) must prepare themselves in advance so that they will be able to handle the probable difficulties.

Tasks to be performed by the student include:

- Based on literature review, present the current state of electric car technology.

- Study and analyze the possible impacts electric cars might have on low-voltage grids.

- Create LV grid models in DIgSILENT Power Factory to investigate these impacts. Conduct asymmetric load-flow simulations with taking the variation of household loads, car home arrivals, different state-of-charge, etc. into consideration and evaluate the obtained results.

Supervisor at the department: $\quad$ Dr. Csaba Farkas, senior lecturer

Budapest, 16. February 2019.

Dr. István Kiss

Associate Professor

Head of Department 
This page intentionally left blank 


\section{Contents}

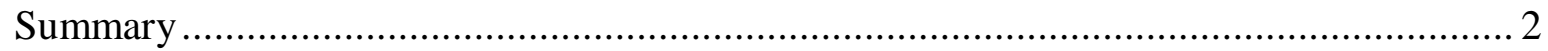

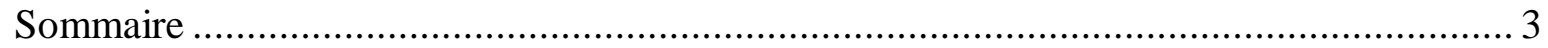

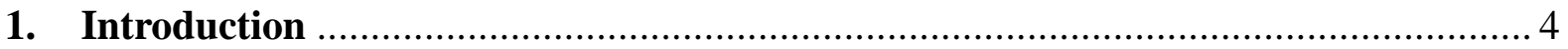

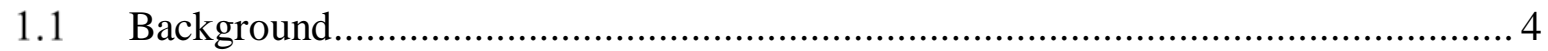

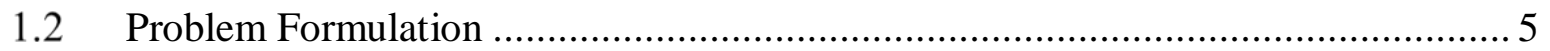

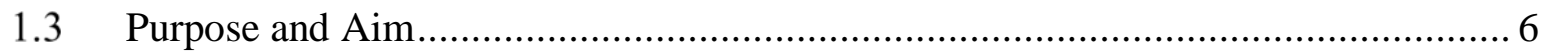

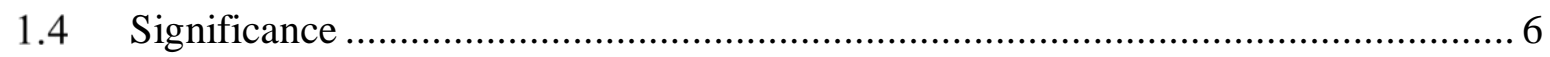

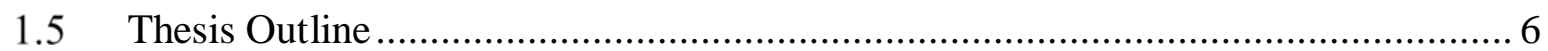

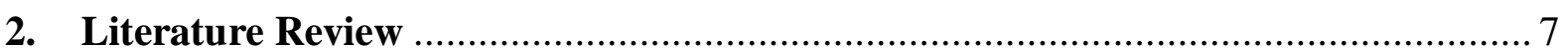

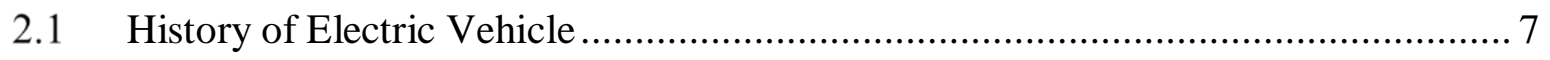

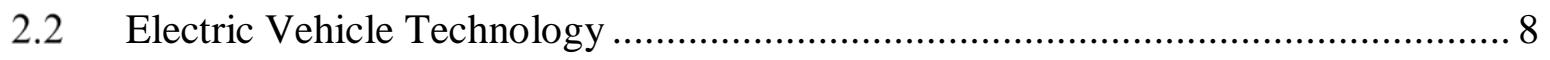

2.2.1 Working of Electric Vehicles .................................................................. 8

2.2.2 Key Components of an Electric Car .......................................................... 9

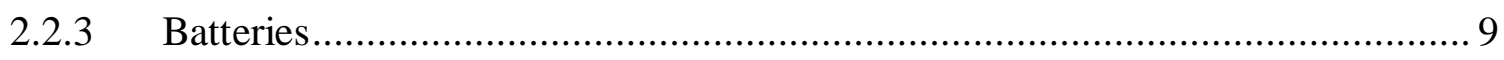

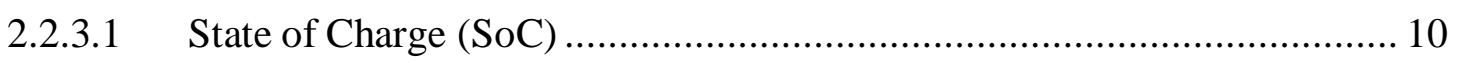

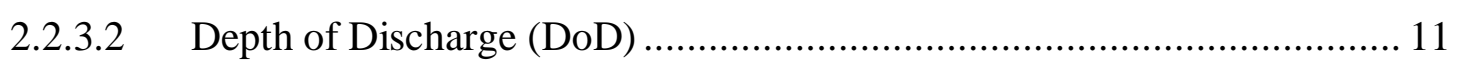

2.2.4 Charging Station and Charging Time ....................................................... 11

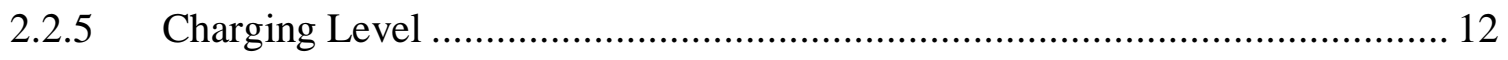

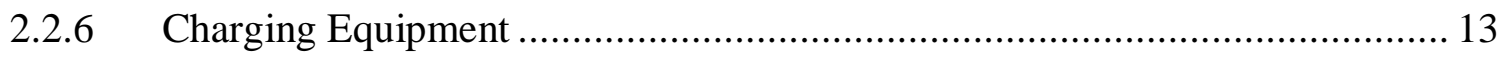

2.3 Chargeable Electric Vehicles.................................................................... 14

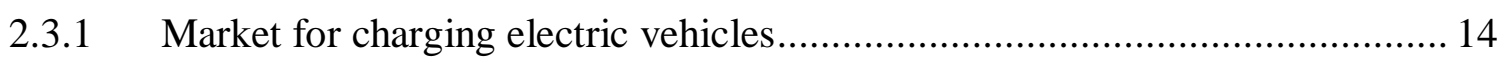

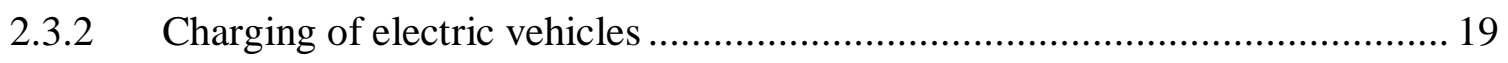

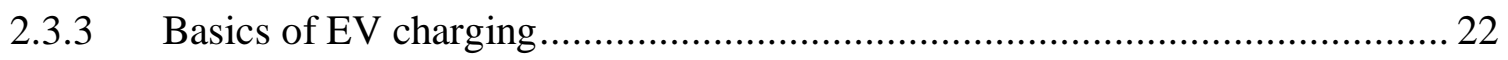

2.4 European Power Distribution Grid ................................................................. 23

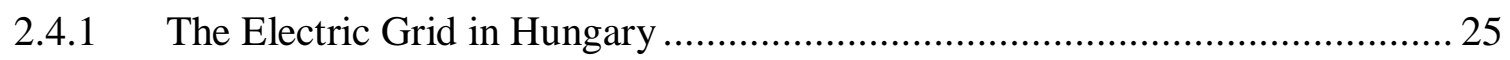

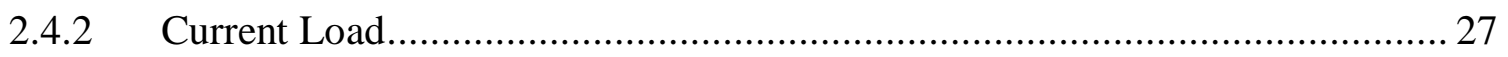

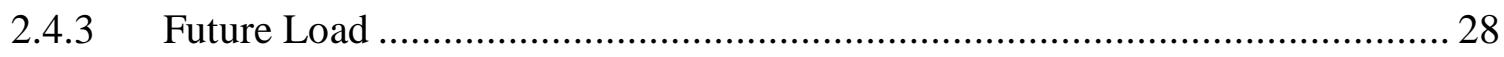

2.5 Impact of EVs on the LV Grid and its Mitigation ...................................... 29

2.5.1 EV load impacts on Electricity Generation ................................................. 29

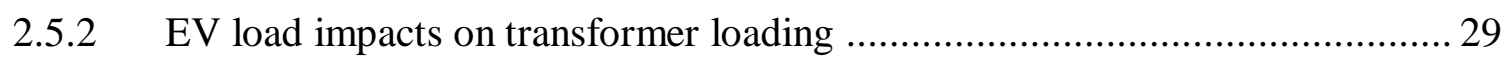

2.5.3 EV load impacts on Power Quality ....................................................... 30

2.5.4 Time-of-Use (TOU) pricing to mitigate EV load impacts .............................. 30

2.5.5 Smart charging algorithms to mitigate EV load impacts .............................. 31

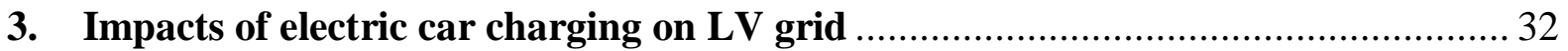




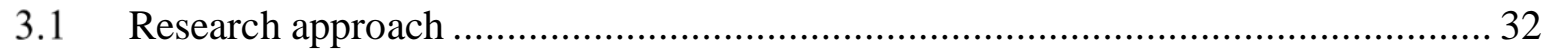

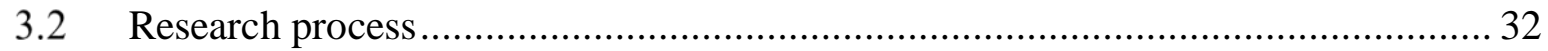

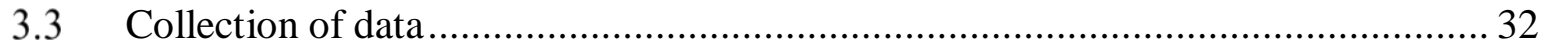

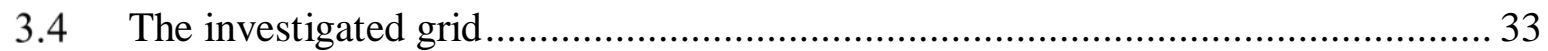

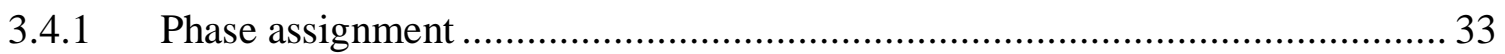

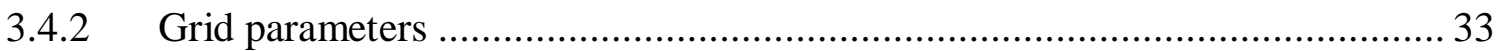

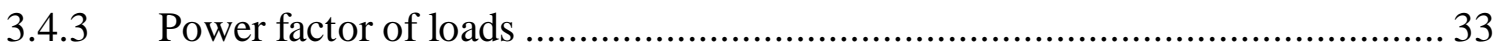

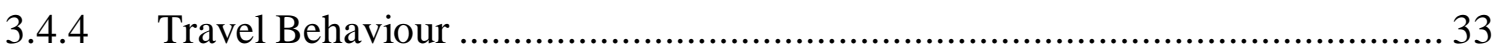

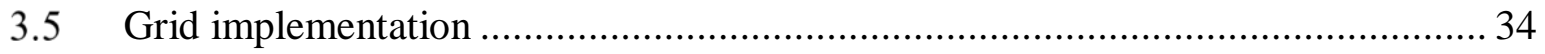

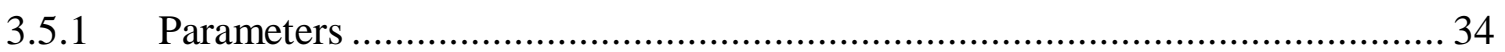

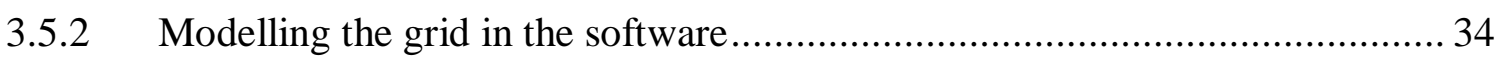

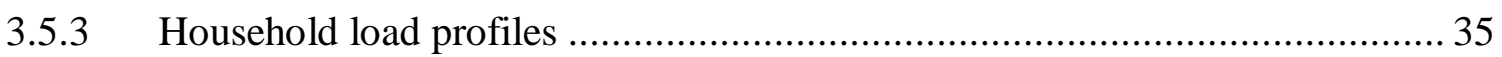

3.5.4 Modelling the electric cars connected to the network ................................... 36

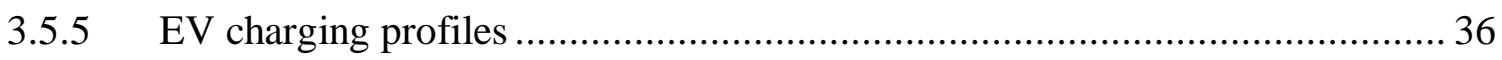

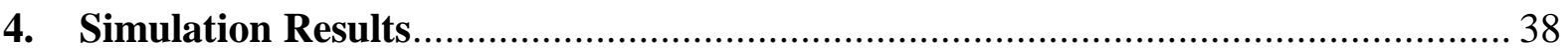

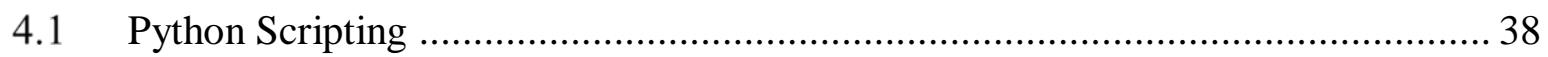

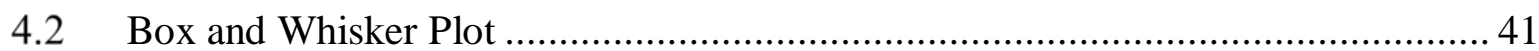

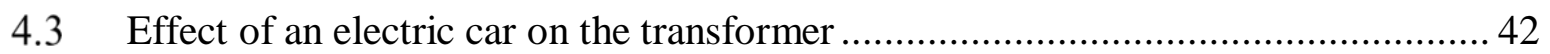

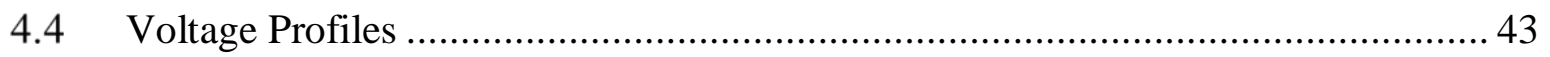

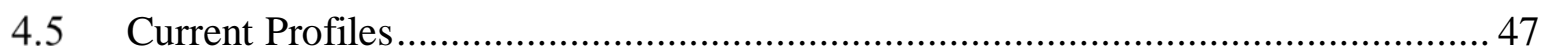

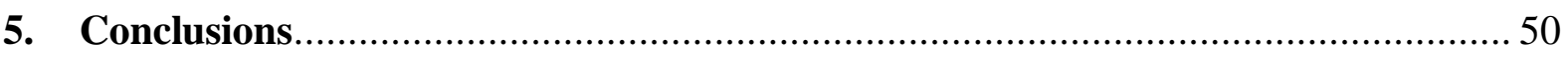

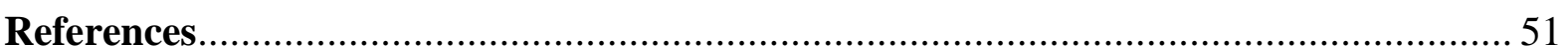




\section{List of Figures}

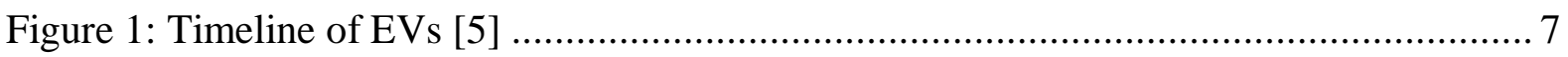

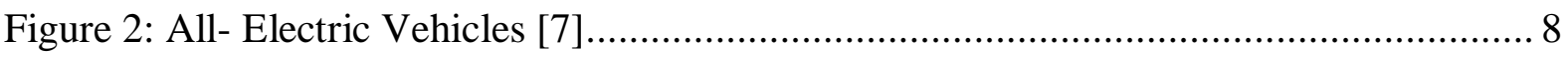

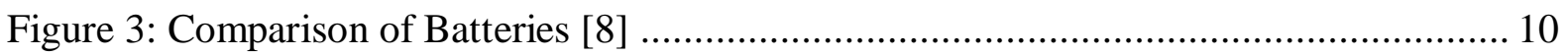

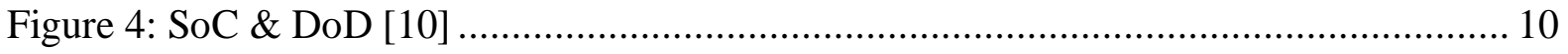

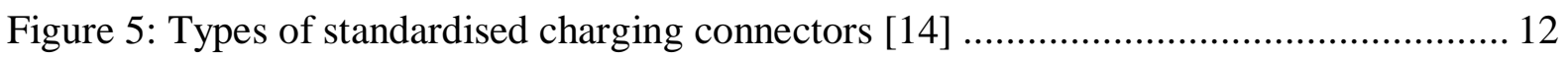

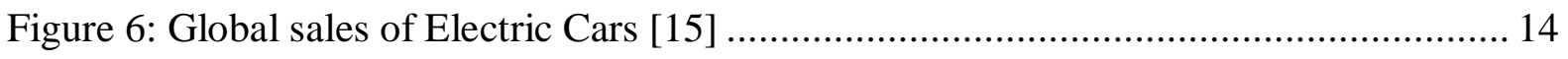

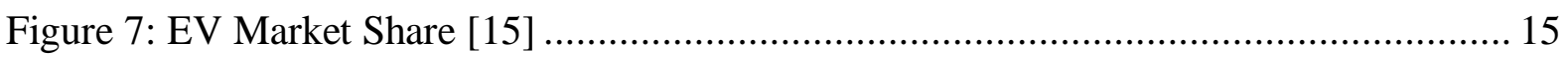

Figure 8: CEV global growth (International Energy Agency 2016) .................................. 15

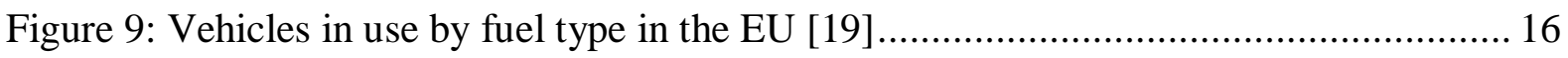

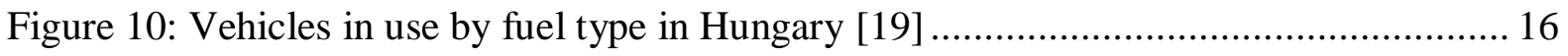

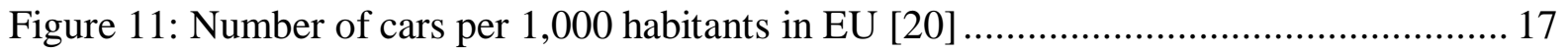

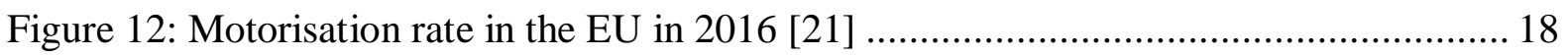

Figure 13: Share of Alternative fuel in different types of Vehicles [22] ........................... 18

Figure 14: Comparison of Charging and Gas stations in US and Japan [23] ...................... 19

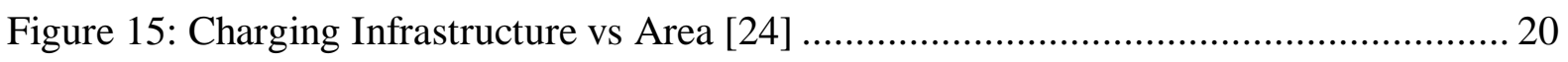

Figure 16: EV Charging Points Distribution across the EU [25] ..................................... 20

Figure 17: Number and Types of charging stations in Hungary [26] ................................. 21

Figure 18: Number of Normal and Fast Charging Points in 2019 [28] .............................. 21

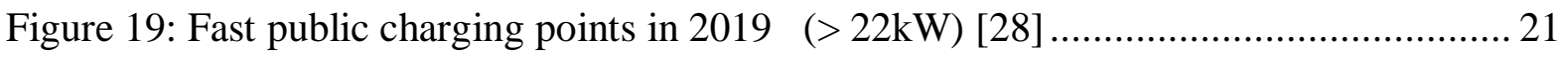

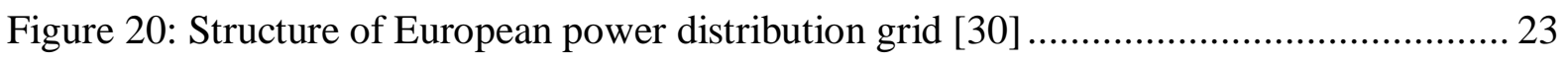

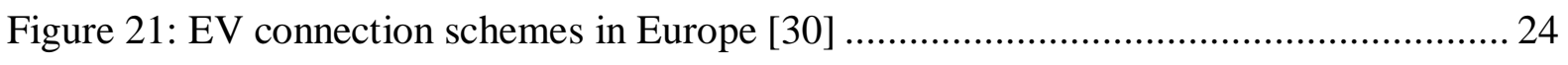

Figure 22: National Electricity Transmission Grid of Hungary [32] ................................ 25

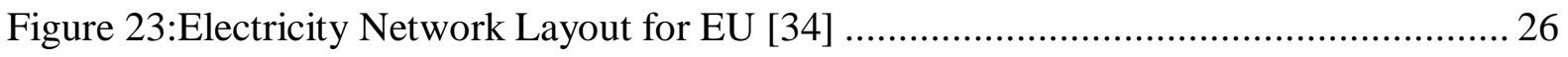

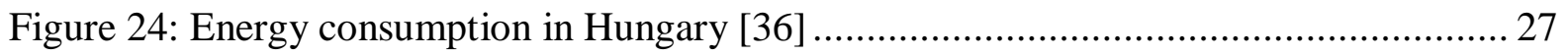

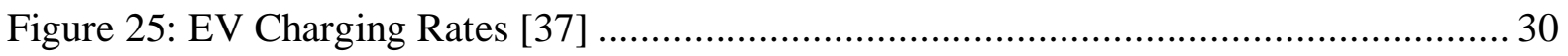

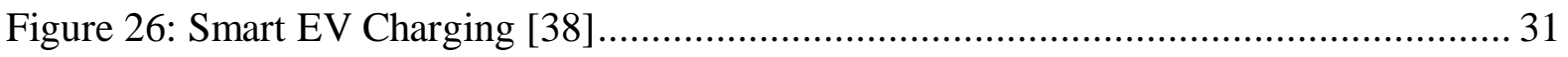

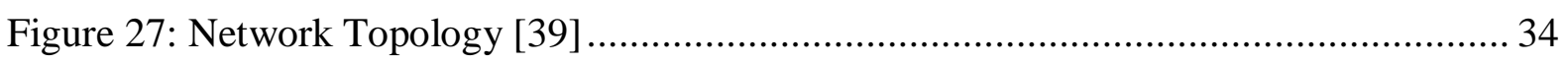

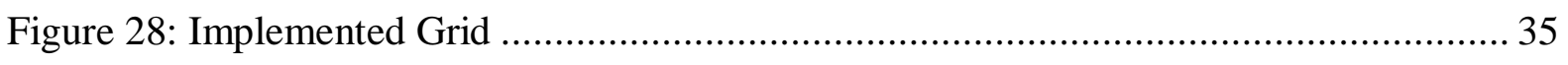

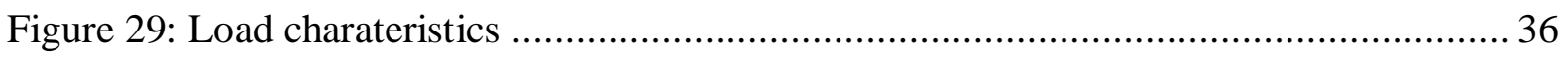

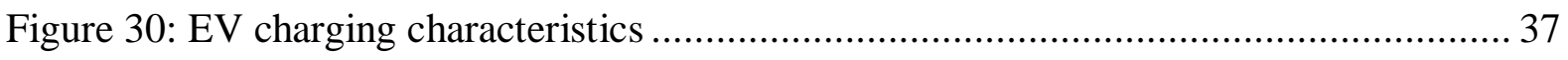

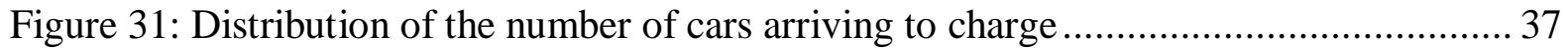

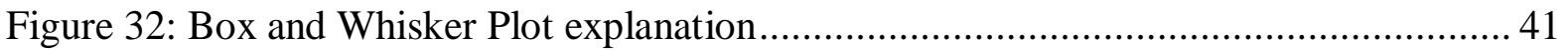




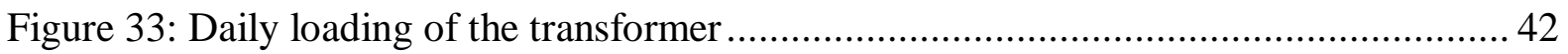

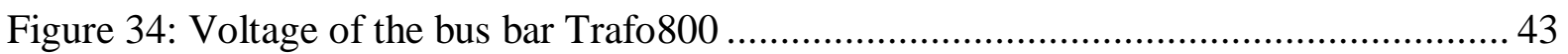

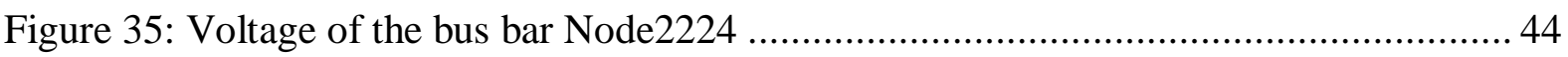

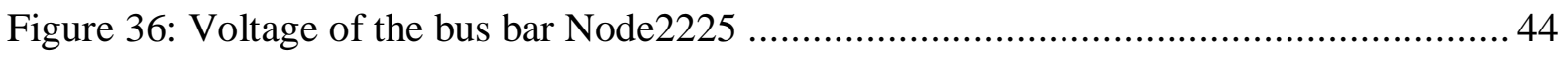

Figure 37: Voltage of the bus bar Node1543 …......................................................... 45

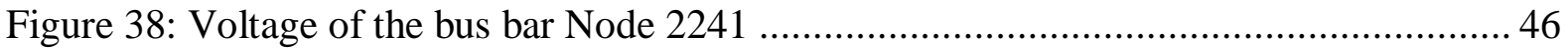

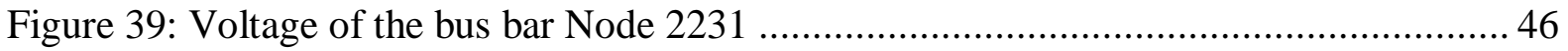

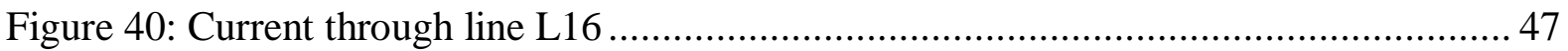

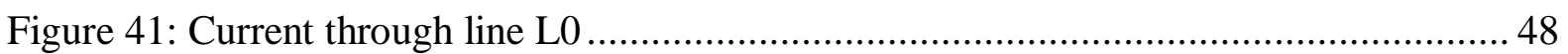

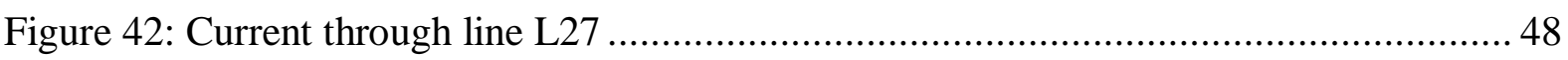

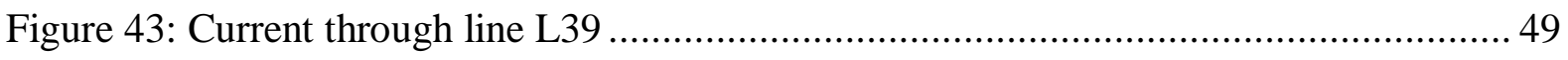

\section{List of Tables}

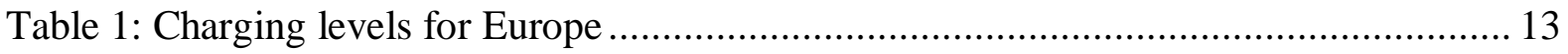




\section{STUDENT DECLARATION}

I, Seerin Ahmad, the undersigned, hereby declare that the present MSc thesis work has been prepared by myself and without any unauthorized help or assistance. Only the specified sources (references, tools, etc.) were used. All parts taken from other sources word by word, or after rephrasing but with identical meaning, were unambiguously identified with explicit reference to the sources utilized.

I authorize the Faculty of Electrical Engineering and Informatics of the Budapest University of Technology and Economics to publish the principal data of the thesis work in a searchable, public, electronic and online database and to publish the full text of the thesis work on the internal network of the university. I declare that the submitted hardcopy of the thesis work and its electronic version are identical.

Full text of thesis works classified upon the decision of the Dean will be published after a period of three years.

Budapest, 17 May 2019 


\section{Summary}

The market for electric cars is presently limited but it is expected to increase rapidly due to the increased environmental concern and technological advancements. Currently, car companies are designing electric cars for daily urban use, therefore in the near future, urban areas might have a large number of electric cars running on their streets during the day. It is obvious that these electric cars need to be recharged for further use which will be done in the evening or during the night. Due to their high-energy capacity, mass deployment of electric cars will have a significant impact on the distribution system, mostly on the LV grid by affecting the network voltage profiles and the loading of the grid elements such as transformer, etc. This impact will call the design of electric cars interface devices and the way future distribution system will be designed and controlled.

In this thesis, we discussed brief the technology behind the electric vehicles, different components and working operation of EVs, most commonly used batteries and time to charge these batteries. We also discussed the different levels of charging and the required charging infrastructure to charge the EVs.

In the next part, we have focused on the global market of EVs, especially in the European Union and Hungary, and the electric grid in Hungary, the present status of current load and future load in Budapest and in the country. Then we discussed the impacts caused by EVs on the grid and mitigation of these impacts by using different methods.

Finally, we model the LV grid in the DigSilent Powerfactory software with parameters such as power factor and base active power of household loads and electric cars. Then, we run the load flow analysis to know how the power flows across each load varies and time sweep analysis to know the loading on the transformer, voltages and currents at different bus-bars and terminals. Then, we analysed the obtained results to acquire the possible issues that electric car charging might have on the LV grid. 


\section{Sommaire}

A villamos autók piacában óriási fellendülés várható a jövőben a környezetvédelmi elöírások változása, ill. a technológiai fejlődés eredményeként. Ma minden autógyártó fejleszt valamilyen villamos autót, így már a közeljövőben jelentős mennyiségü villamos autó megjelenésével kell számolni az utakon. Ezeket a jármüveket tölteni kell, amit az esti-éjjeli időszakban lehet megtenni. Az autók energiaigénye jelentősnek mondható, így elterjedésük várhatóan komoly hatással lesz a kisfeszültségü villamos hálózatra, hatással lesz a fogyasztási profilokra és a hálózati elemek terhelődésére, így az elosztóhálózat üzemeltetésének újragondolására lehet szükség a jövőben.

A diplomatervben a villamos autók technológiájának áttekintése (jármútípusok, akkumulátortípusok, töltési módok, töltőinfrastruktúra) áttekintése után a villamos autók elterjedésének jelenlegi állapotát vizsgáltam meg, elsősorban az EU és Magyarország területére fókuszálva. Bemutatom a hálózaton várható hatásokat, valamint ezek demonstrálására egy kisfeszültségü hálózatmodellt építettem DIgSILENT Powerfactory szoftverkörnyezetben. A megépített hálózaton load-flow vizsgálatokat elvégezve meghatároztam a hálózati elemek (vezetékek, transzformátor) terhelődését, a csomópontokon mérhető feszültségek nagyságát, végül a szakirodalom alapján ismertettem az okozott hatások mérséklésére alkalmas megoldásokat. 


\section{Introduction}

This section introduces the background of the thesis and presents the problem formulation, purpose and significance as well as the definition of research questions, delimitations etc. Finally, the disposition of the report is mentioned that how the thesis is structured.

\subsection{Background}

The transformation of the global energy sector from conventional sources to renewable sources is ongoing research nowadays. The main reason for this is to reduce greenhouse gases like CO, $\mathrm{CO}_{2}$ emissions to limit climate change. We need an urgent action globally to reduce the carbon intensity from the energy sector and also need to take further action to reduce carbon emissions and mitigate the effects of climate change even if the global energy transition is in progress. Carbon emissions can be reduced by more than $90 \%$ by adopting renewable energy and energy efficiency measures [1]. Energy production and storage are becoming increasingly decentralised and renewable energy production is becoming competitive with conventional generation.

As a part of this transition, there has been a surge in demand for Chargeable Electric Vehicles (CEVs). Large investments and significant political incentives are driving the production costs down, leading to an eventual tipping point for sales of CEVs. This will cause a shift in energy distribution, putting a larger strain on the distribution grid and lead to a decreased demand in energy sources such as gas and diesel.

To put this in perspective, the total consumption amounted to 39.37 billion $\mathrm{kWh}$ of electric energy per year in 2015 . This is an average of $4,025 \mathrm{kWh}$ per capita and $77 \%$ of the countries own usage and the rest of the energy is imported from the neighbouring countries. In 2015, renewable energies accounted for around 15.6 per cent of total actual consumption in Hungary $[2]$.

According to the Hungarian central statistical office, the total number of passenger cars were 3313206 in 2016 in Hungary. [3] As of July 18th 2016 there were roughly 932 vehicles in Hungary that could be charged with electricity in which most of them are in Budapest and in the surrounding Pest county. The number of electric vehicles is increasing day by day and it is projected that it will cross the mark of 10,000 by the end of 2020 according to the heads of the 
Hungarian Association of Vehicle importers but it requires a huge investment in infrastructure like charging stations, etc. [4]

Power makers are always attempting to match the demand and supply in the system and this procedure has been moderately unaltered and steady. People sleep at night, wake up in the morning, take breakfast, go to work, come back from work, prepare dinner and go to bed. This is the typical daily routine of individuals and the primary driver for the electricity demand on a local level. The dimension of the distribution grid today is taken according to the geographic location and type of households and its planning process is long and needs to account for changes in demand expected in the future. While there is uncertainty in terms of what will happen when the electrification of the transport sector is inevitably going to affect grid planning activities.

\subsection{Problem Formulation}

A major and dramatic increase in Chargeable EVs will not happen overnight, however, it is likely that all actors in the Hungarian electric grid will see its effects in the upcoming 5-10 years. Given that the total energy consumed by passenger cars is comparable to the total amount of electricity generation in Hungary, it is relevant to evaluate the increased variations of the grid load. These variations may be compatible with the current load profiles, resulting in a flatter demand profile, or they may cause extreme load peaks and put an unbearable strain on the grid. Since charging of electric vehicles is not one of the criteria that is taken into consideration when dimensioning distribution grids, and the planning process is long, the knowledge gap of EVs impact on the grid is becoming a more pressing issue.

Specifically, there is little knowledge of how this will affect specific urban areas, such as Budapest. The problem is not primarily regarding the average demand and the average capacity, but rather what will happen in certain extreme scenarios, for example, during the end of the day when people come home from work, on holidays taken by car, etc. The current unpredictability and uncertainty may cause distress in the electric grid once sales of EVs start to pick up. This distress may cause larger load peaks in the grid, requiring a need to expand the distribution and transmission capacity, which is very costly. The increased demand may, however, end up causing a better balance in the demand, for example, by EVs charging during low peak demand hours. 


\subsection{Purpose and Aim}

The purpose of this thesis is to present the current state of electric car technology and to investigate and analyse the possible impacts of electric cars on the low-voltage grids.

\subsection{Significance}

This study will clarify the problems on Low Voltage Grid while installing charging infrastructure. The LV Grid usually supplies power to a small number of houses and loads. If the charging station is installed and used during peak hours, harmonics production due to electronic devices can cause problems in the LV Grid. As time passes with improvement in technology we will be able to remove all the ICE Driven vehicles which will be helpful in reducing the greenhouse gases and hence the environment will be cleaner and much safer for the future generations.

\subsection{Thesis Outline}

The thesis starts by giving the reader background and problem formulation of the chosen area of research. Then it includes the purpose, significance and aim of this research. The introduction chapter ends with describing the outline of the thesis. Literature Review provides the needed knowledge and theory in different areas, in order to conduct the research in a good way. The chapter includes research on the development of technology of chargeable electric vehicles, data of electric vehicles in Hungary and how the electric grid works. Then it describes how the research has been conducted in order to achieve the purpose and aim of the study. It starts with describing the research approach and the research process, followed by explaining how the grid is designed with the collection of data and the analysis of the model outcome will be done. After that, it summarizes the answers to the research questions asked in the beginning of the thesis and discusses scenarios about possible electric car impacts on low voltage grids. 


\section{Literature Review}

This section presents the required background and relevant conducted research for the thesis. Firstly, a general background is provided on the electric vehicle technology, CEV market, and the CEV charging infrastructure.

\subsection{History of Electric Vehicle}

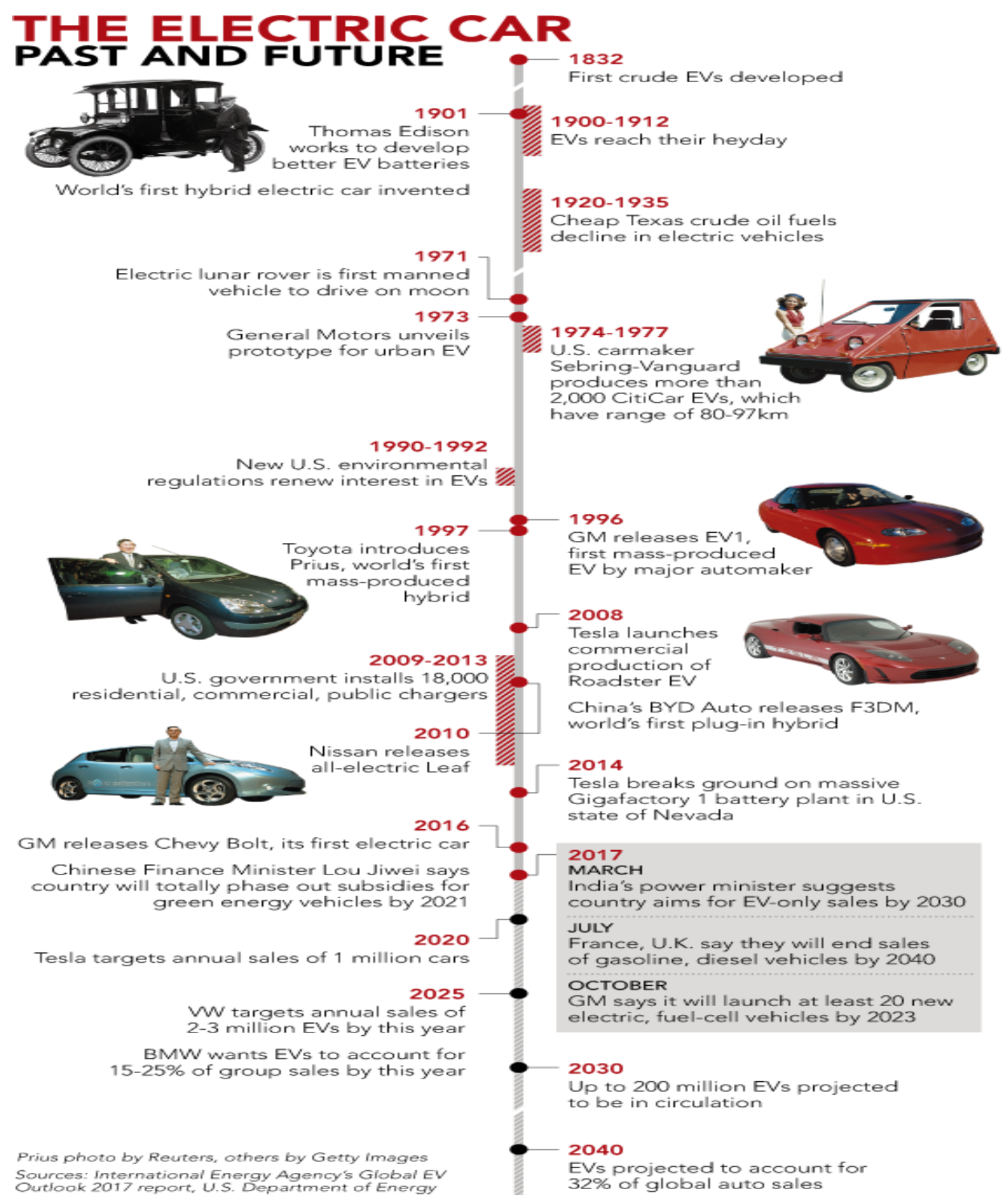

Figure 1: Timeline of EVs [5] 
The history of electric cars began in the mid-19th century. In 1828, Ányos Jedlik, a Hungarian who invented an early type of electric motor created a small car model powered by the new type of engine. In 1834 in Vermont, Thomas Davenport invented the first American DC electric motor. Rechargeable batteries that provide a viable way to store electricity in the car did not exist until 1840. Interest in motor vehicles increased greatly in the late 1890 s and early 1900s. But, at the beginning of the 20th century, the electric car began to lose its position in the automobile market due to its slow speed, low range, wide availability of affordable gasoline, and expensive operation [6]. After that electric vehicles gain attention in the 1970s due to global warming, greenhouse gas problems.

\subsection{Electric Vehicle Technology}

Electric vehicles (EVs) use a pack of batteries to store the electrical energy that powers the motor. The batteries are charged by plugging the vehicle in to a power source in a charging station. The electric motor behaves like a generator during braking which charges the batteries.

\subsubsection{Working of Electric Vehicles}

Electric vehicles (EVs) have an electric motor instead of an internal combustion engine. The electric motor is powered by the large traction battery pack and plugged-in to a charging station to charge [7]. It runs on electricity, therefore, the vehicle emits no exhaust from a tailpipe and does not contain the typical liquid fuel components, such as a fuel pump, fuel line, or fuel tank.

\section{All-Electric Vehicle}

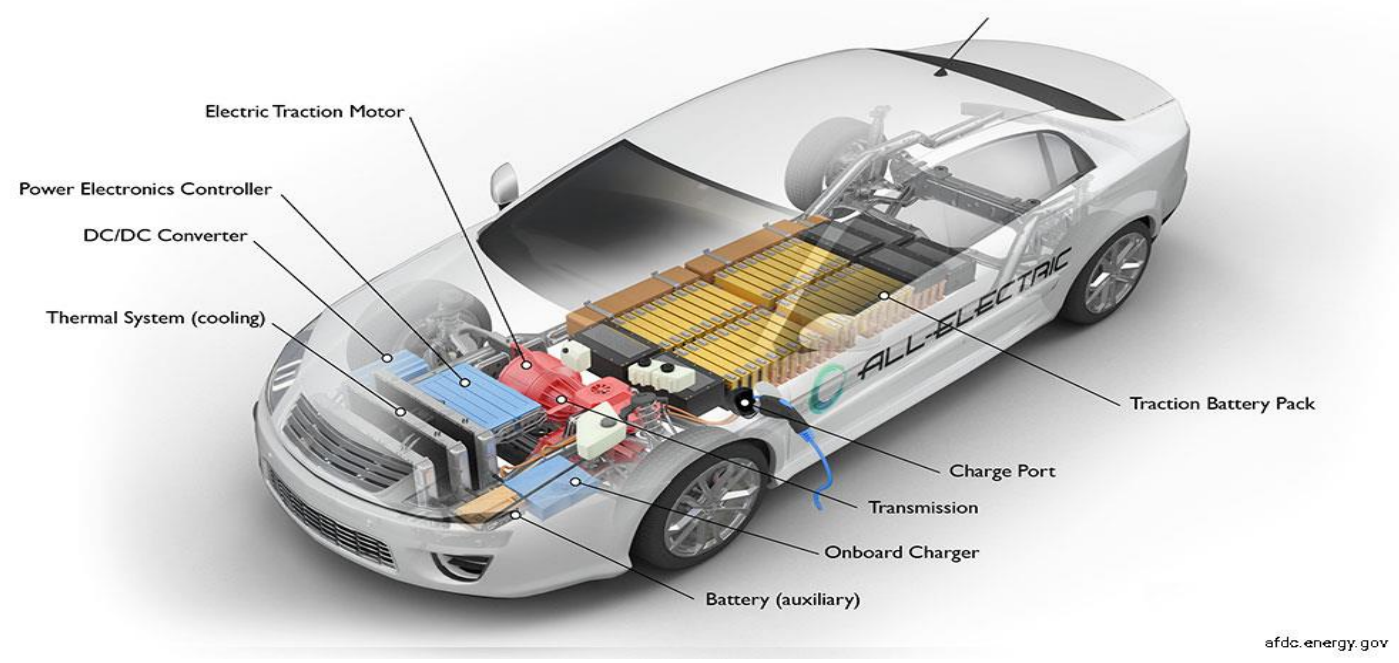

Figure 2: All- Electric Vehicles [7] 


\subsubsection{Key Components of an Electric Car}

The components of the electric car are shown in Figure 2.

Battery: The batteries provide electricity to power vehicle accessories in electric drive vehicles.

Charge Port: The charge port connects the vehicles to an external power supply in order to charge the battery pack.

DC/DC Converter: It converts higher-voltage DC power from the traction battery pack to the lower-voltage DC power needed to run vehicle accessories and recharge the auxiliary battery.

Electric Traction Motor: It drives the vehicle's wheels using power from the traction battery pack. The motor sometimes acts as a generator during braking.

On-Board Charger: It takes the AC electricity via the charge port and converts it to DC power to charge the traction battery. Battery characteristics such as voltage, current, temperature, and state of charge while charging the pack is monitored.

Power Electronics Controller: It manages the electrical energy flow, controls the speed of the electric motor and the torque it produces.

Thermal System: This system maintains a proper operating temperature range of the engine, electric motor, power electronics, and other components.

Transmission: The transmission transfers mechanical power from the electric motor to drive the wheels of the electric vehicles.

\subsubsection{Batteries}

Energy storage systems like batteries are a fundamental component of hybrid electric vehicles (HEVs), plug-in hybrid electric vehicles (PHEVs), and all-electric vehicles (EVs).

The high energy per unit mass, high power-to-weight ratio, high energy efficiency, hightemperature performance, and low self-discharge properties of Lithium-ion batteries has led to the most used batteries in portable consumer electronics such as cell phones and laptops. This battery is recyclable but the recovery cost is very high and it is a challenge for the industry. Nickel-metal hydride batteries, lead-acid batteries are also other options but it is not as effective as lithium-ion and is decreasing day by day. The comparison of different batteries is shown in Figure 3 in which lithium NCA batteries has the largest specific energy capacity than other batteries types. 


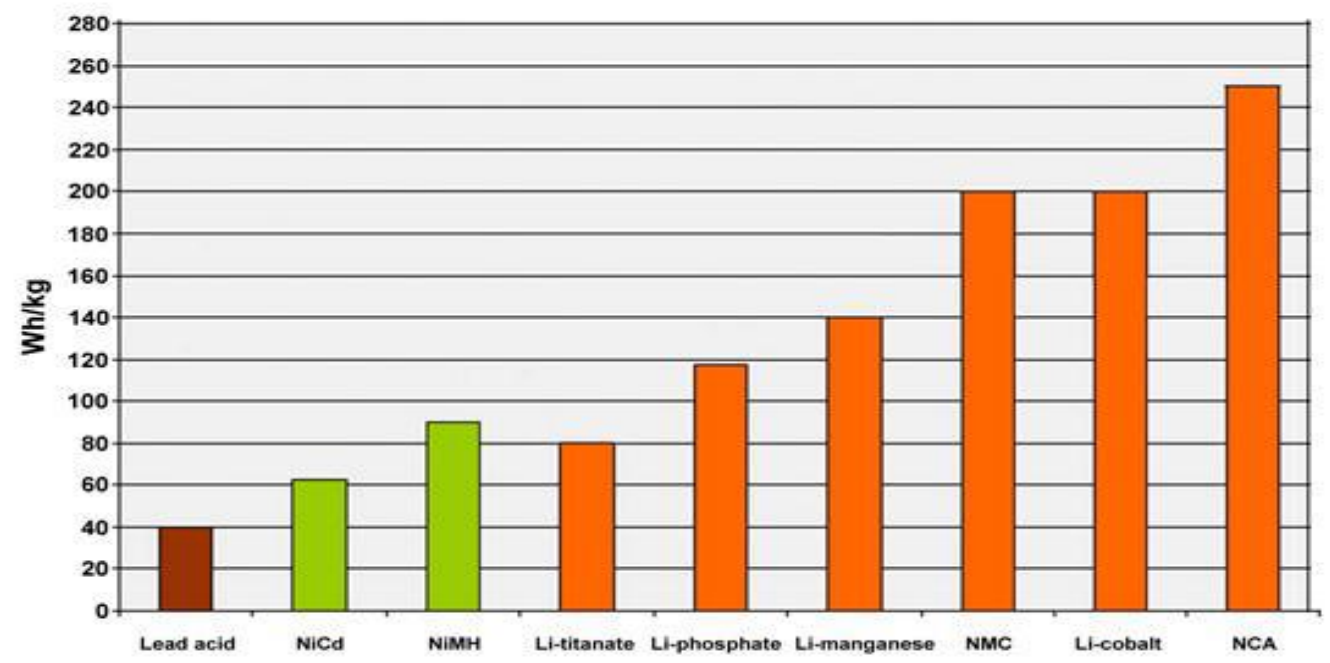

Figure 3: Comparison of Batteries [8]

\subsubsection{State of Charge (SoC)}

It is defined as the ratio of the current capacity of the battery to the maximum amount of charge that the battery can store. It is an equivalent of a fuel gauge for the battery pack in a chargeable electric vehicle. The units of SoC are percentage points i.e. $0 \%$ means empty and $100 \%$ means full. The SoC is equal to $100 \%$ when the DoD is $0 \%$, and $0 \%$ when the DoD is $100 \%$. It is normally used when discussing the current state of a battery in use [9]. The concept of SoC and DoD is shown in Figure 4.

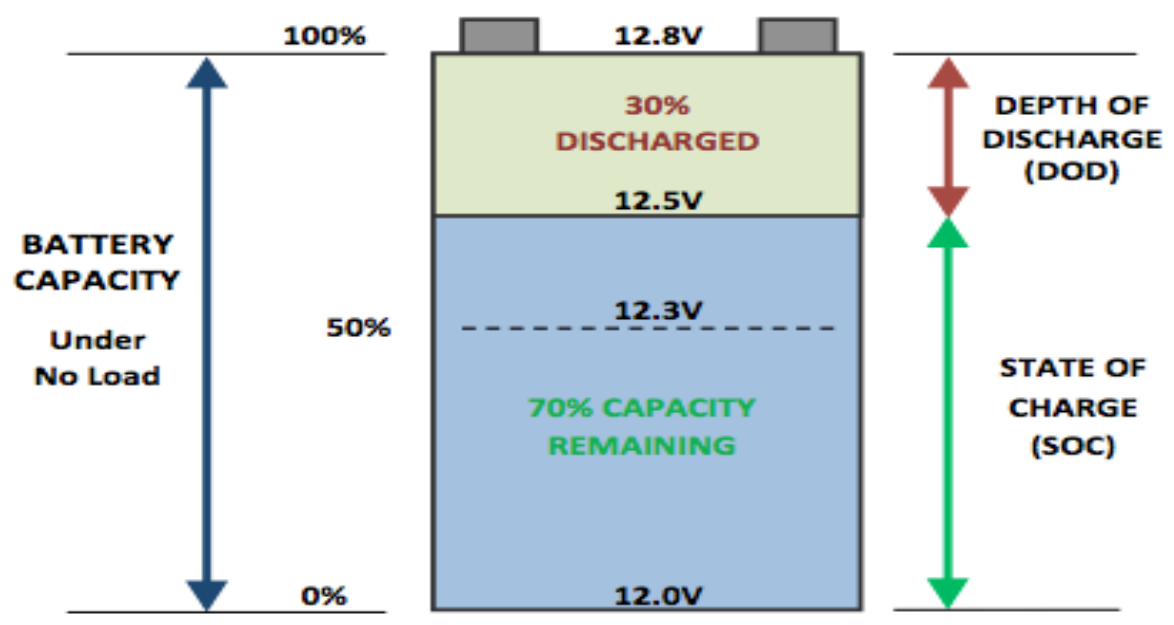

Figure 4: SoC \& DoD [10] 


\subsubsection{Depth of Discharge (DoD)}

The DoD is the complement of SoC. It measures how deeply depleted the battery is, compared to a state of full discharge when it would have discharged all of its energy capacity. It is expressed as a percentage of the total battery capacity. When a battery has discharged its full energy capacity, the Depth of Discharge, or DoD, is $100 \%$. When the battery is fully charged, its DoD is 0\%. For example, if you have a 100 Amp hour battery and use 50 Amp hours you have discharged the battery $50 \%$ which means the depth of discharge is $50 \%$ [11].

\subsubsection{Charging Station and Charging Time}

For the recharging of batteries of electric vehicles, such as electric cars we need an electric vehicle charging station that supplies power. Consumers access charging stations, also called electric vehicle supply equipment to charge their vehicles. The charging of vehicles can take place at home, at workplaces and at public places.

The battery capacity and the charging power are the main factors in charging time. The charging level determines the time rate of the charge which depends on the voltage handling of the batteries and charger electronics in the car.

Refuelling a traditional car takes only a couple of minutes while recharging a CEV takes atleast a couple of hours and it is one of the biggest problems when we consider electric cars. The slowest charging alternative currently being used is that which corresponds to the power available in a normal socket. In Hungary, there is 230 volts and 10 amperes, thus $2.3 \mathrm{~kW}$ of available power. The time it takes to charge an electric car can be as little as 30 minutes or more than 12 hours. This depends on the size of the battery and the speed of the charging point. A typical electric car (60kWh battery) takes just under 8 hours to charge from empty-tofull with a $7 \mathrm{~kW}$ charging point [12]. Nowadays, the available charging options are in the range of $2.3 \mathrm{~kW}-145 \mathrm{~kW}$. 


\subsubsection{Charging Level}

There are three levels of charging available for EVs today: Level I, Level II, and DC Fast Charging. [13]

- Level 1: It simply requires a 240-volt outlet. All electric vehicles come equipped with a cord that you can plug into a common outlet. A Level I charge uses the J1772 charging port and will typically add 4 to 10 kilometres of range for every hour spent charging (the actual speed depends upon the capacity of the charger built into your EV).

- Level 2: It requires a 400-volt outlet and a charging unit. A Level II charge uses the J1772 charging port and will typically add 16 to 40 kilometres of range for every hour spent charging (the actual speed depends upon the capacity of the charger built into your EV).

- DC Fast Charging: It is the fastest charging available for passenger cars (other than Tesla). It is increasingly available along major highways and intended for longer trips. American and European manufacturers use the J1772 combo (otherwise known as CCS DCFC or SAE Combo) and Asian manufacturers use the CHAdeMO.

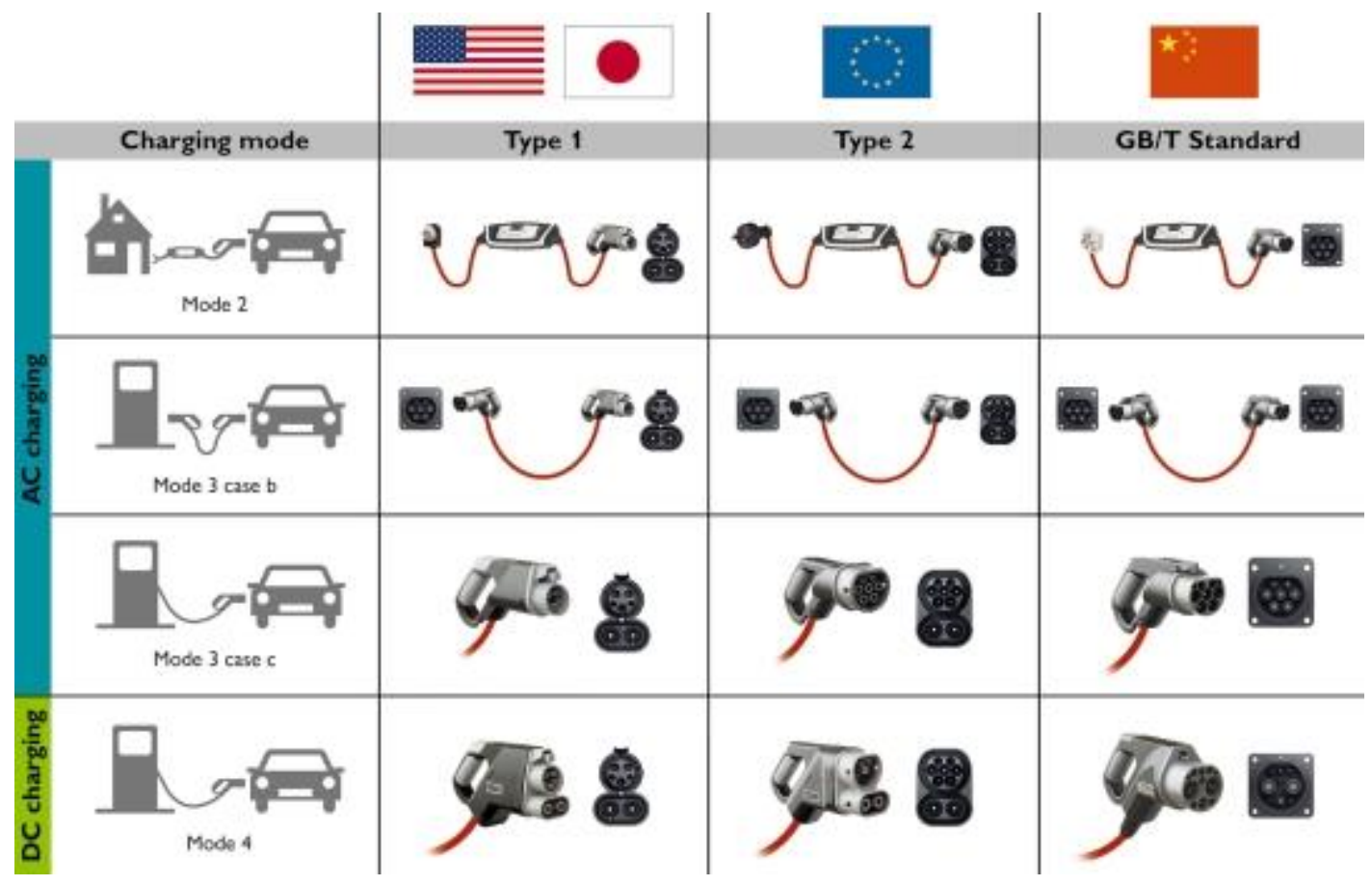

Figure 5: Types of standardised charging connectors [14]

Figure 5 shows the different charging modes and different types of charging connectors used in USA, China and European Union. 
Table 1: Charging levels for Europe

\begin{tabular}{|l|c|c|c|}
\hline & Level I & Level II & DC Fast Charging \\
\hline Voltage & $\begin{array}{c}\text { Single-phase } \\
240 \mathrm{~V} \mathrm{AC}\end{array}$ & $\begin{array}{c}\text { Three-phase } \\
400 \mathrm{~V} \mathrm{AC}\end{array}$ & $480 \mathrm{~V}$ DC \\
\hline Charging Speed & $\sim 2-6 \mathrm{miles} / \mathrm{hr}^{*}$ & $\sim 10-25 \mathrm{miles} / \mathrm{hr}^{*}$ & $\sim 60-90 \mathrm{miles} / 30 \mathrm{~min} *$ \\
\hline Charging Port & $\mathrm{J} 1772$ & $\mathrm{~J} 1772$ & $\mathrm{~J} 1772$ combo or CHAdeMO \\
\hline
\end{tabular}

*Depending on the on-board charger capacity and level and battery size [13].

\subsubsection{Charging Equipment}

Charging equipment for plug-in electric vehicles are grouped by the rate at which the batteries are charged. Depending on some factors, the charging can take time less than 20 minutes to 20 hours or more. The charger is built into the electric vehicle. The charging port accepts electricity from an outside source and stores it in the vehicle's battery. [13]

J1772 charge Port Built into all non-Tesla electric vehicles, suitable for Level I or Level II charging. All EVs come with a cord that plugs into the J1772 port in the vehicle on one end and a $240 \mathrm{~V}$ outlet on the other end.

J1772 combo Built into American and European EVs (like the Chevrolet Bolt, BMW i3, Volkswagen e-Golf, etc.) for DC Fast Charging. The J1772 combo is also known as the CCS DCFC or SAE Combo. Cars with the J1772 combo port can plug in Level I, Level II, and fast charging cables into this one port. [13]

CHAdeMO: Built into Asian EVs (like the Nissan LEAF or Mitsubishi Outlander) for DC Fast Charging. That means Asian EVs that can fast charge have two separate ports (J1772 and CHAdeMO).

Tesla: Teslas have unique charge ports and connectors that matches Tesla's proprietary charging network. 


\subsection{Chargeable Electric Vehicles}

This subsection discusses the development within the CEV industry. This includes the sales trends, development from different car manufacturers and the charging infrastructure.

\subsubsection{Market for charging electric vehicles}

The market for electric vehicles is increasing very rapidly. The record global sales of more than 1.1 million electric cars was in 2017. Global sales increased to 54\% in 2017 which is helping electric vehicles to meet the target of sustainable development scenario, SDS. The global stocks of electric cars passed 3 million marks in 2017 in which $40 \%$ of the electric car was on the roads of China which were just $10 \%$ in 2013. This is illustrated in Figure 6 [15].

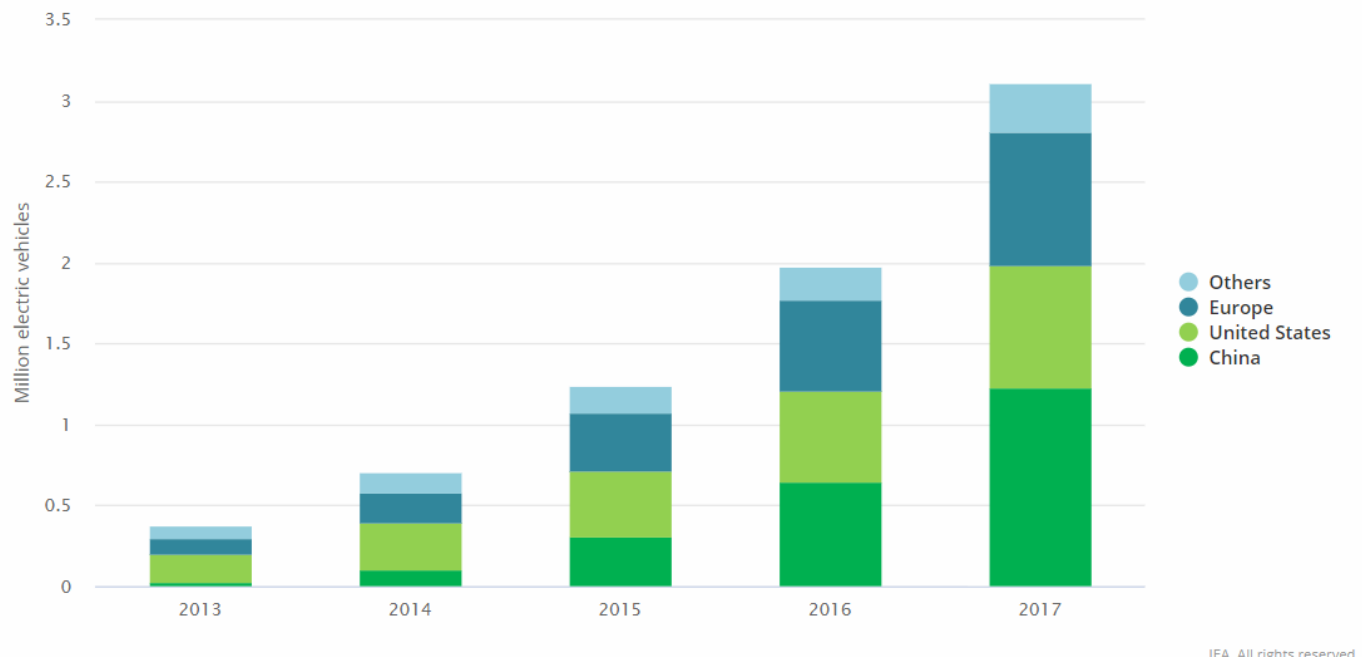

Figure 6: Global sales of Electric Cars [15]

China is today the biggest CEV market in terms of the number of cars sold with roughly half of all new CEV (350,000) sold in 2016. Electric vehicles include both Battery Electric Vehicles (BEVs) and Plug-in Hybrid Electric Vehicles (PHEVs). The share of Battery Electric Vehicles, BEVs in the overall electric car stock continued to grow at moderate rates, rising from $58 \%$ in 2013 to $62 \%$ in 2017. However, the sales of Plug-in Hybrid Electric Vehicles have also increased in the same time frame in the European and Chinese markets.

In terms of the market share of electric vehicles, Norway has by far the largest market share [15]. The Figure 7 below shows the Electric Market share in the top 8 EVs initiative countries. 


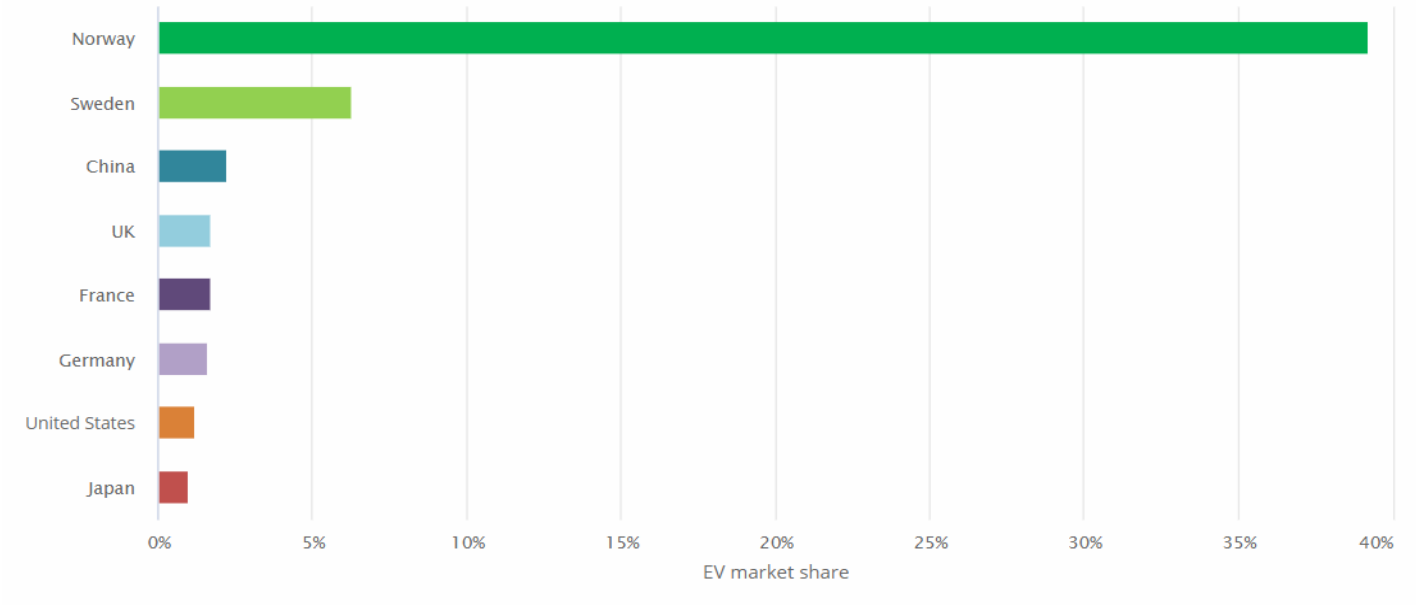

Figure 7: EV Market Share [15]

According to Budapest Business Journal, there are more than 3000 electric vehicles in the roads in Hungary till August 2017 but by the end of 2023, these numbers can exceed to 52,000 which would represent $1.35 \%$ of all motor vehicles (projected at 3.9 million) [16]. Off all grid-enabled electric vehicles, nearly $88 \%$ will be plug-in hybrid cars by 2023; the proportion of all-electric vehicles will be close to $12 \%$. The energy use can be attained to 48 TWh by 2023 if we take into an account $1.5 \%$ annual growth in electricity demand in Hungary [17].

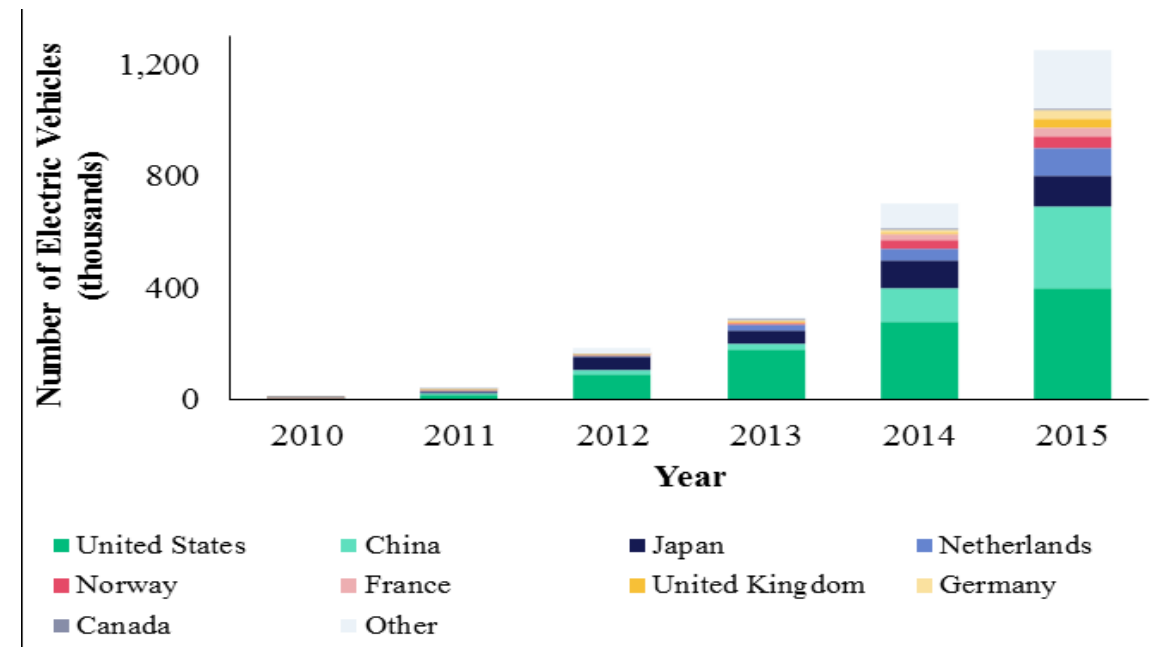

Figure 8: CEV global growth (International Energy Agency 2016)

The number of electric cars in the market has increased a lot during the last four years. About 5 times more electric cars were sold in the country in 2017 as compared to 2013. According to the Hungarian Leasing Association, there were 795 electric cars out of 116 thousand cars in Hungary in 2017. The main reason for this could be that the distance taken by the electric car 
cannot be compared to the distance taken by the traditional cars with internal combustion engines. Therefore, it is very important to create an effective charging network in the country for electric cars. [18]

It is predicted that by the year 2030, the alternative vehicles-electric and hybrid cars will not account $50 \%$ of the total fleet of the vehicles. Presently, in terms of fossil fuels more than half of all European passenger cars (55.6\%) run on petrol. [19]
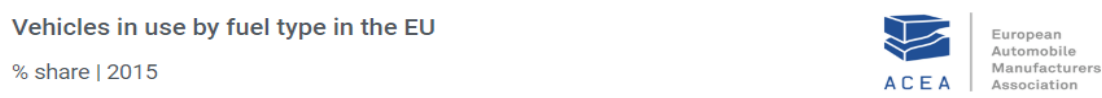

\section{EUROPEAN UNION}

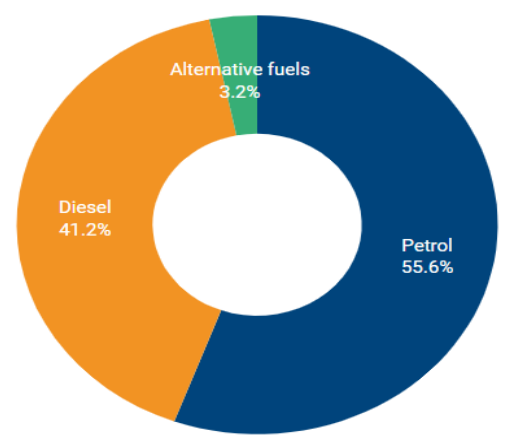

Figure 9: Vehicles in use by fuel type in the EU [19]

Similarly, we can see from Figure 10 that petrol is the dominant source of running vehicles on the roads in Hungary. Diesel is the second most common source to run the vehicles. Hungary is very far away from using vehicles from renewable sources like solar etc.
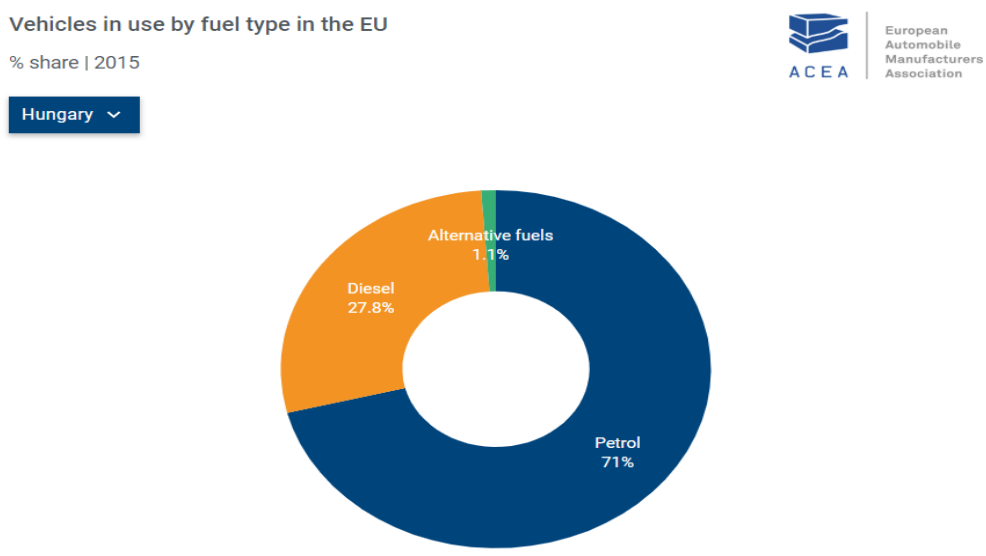

Figure 10: Vehicles in use by fuel type in Hungary [19] 
The Figure 11 depicts the number of passenger cars in the 28 European Union member states for every thousand inhabitants between 1990 and 2016 [20].

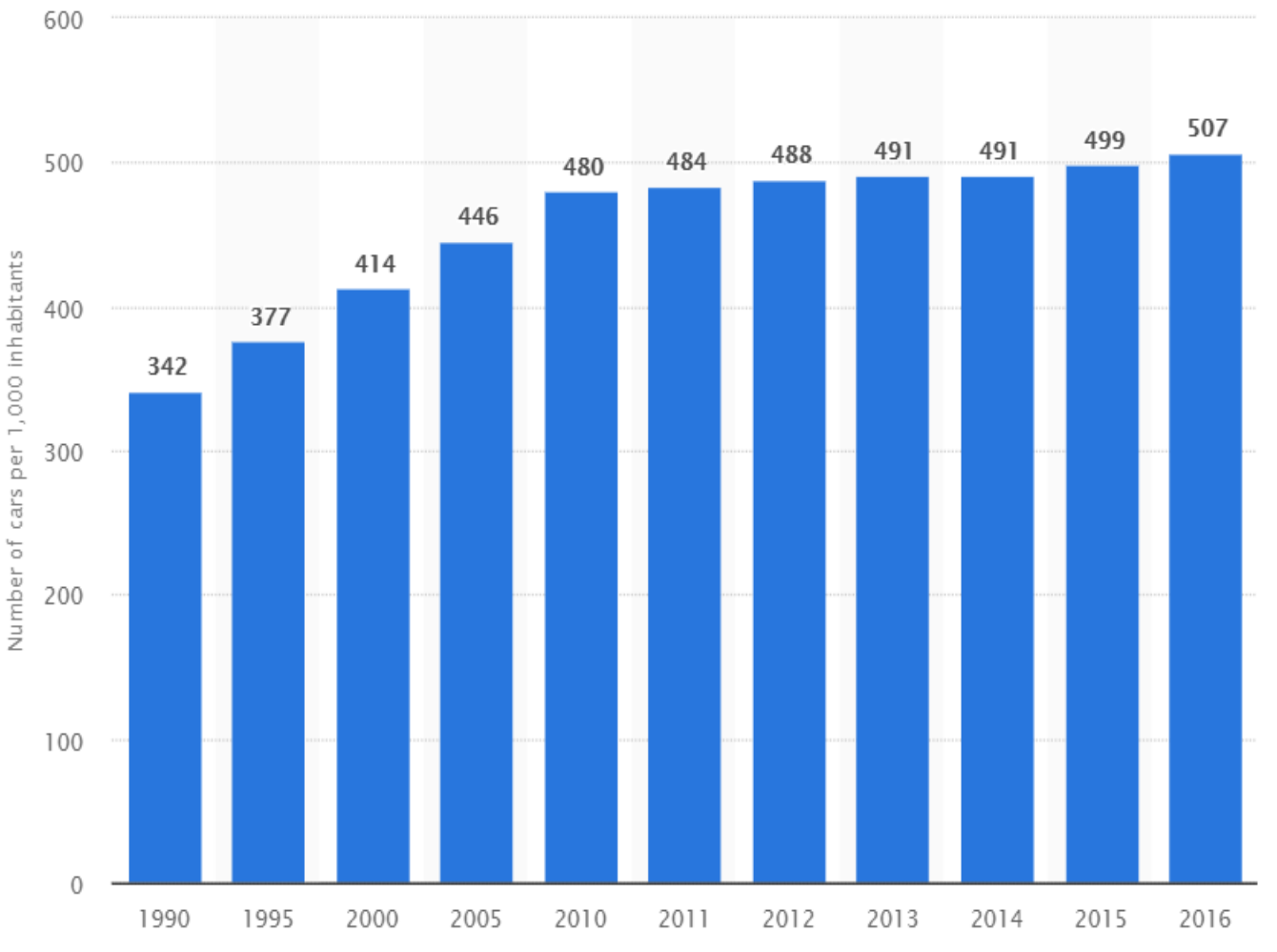

Figure 11: Number of cars per 1,000 habitants in EU [20]

The European Union counts 587 passenger cars per 1,000 inhabitants. [21]

Over $5 \%$ of all passenger cars on Europe's roads run on alternative fuels, but only $1.5 \%$ of all light commercial vehicles and $2.1 \%$ of buses [22]. 


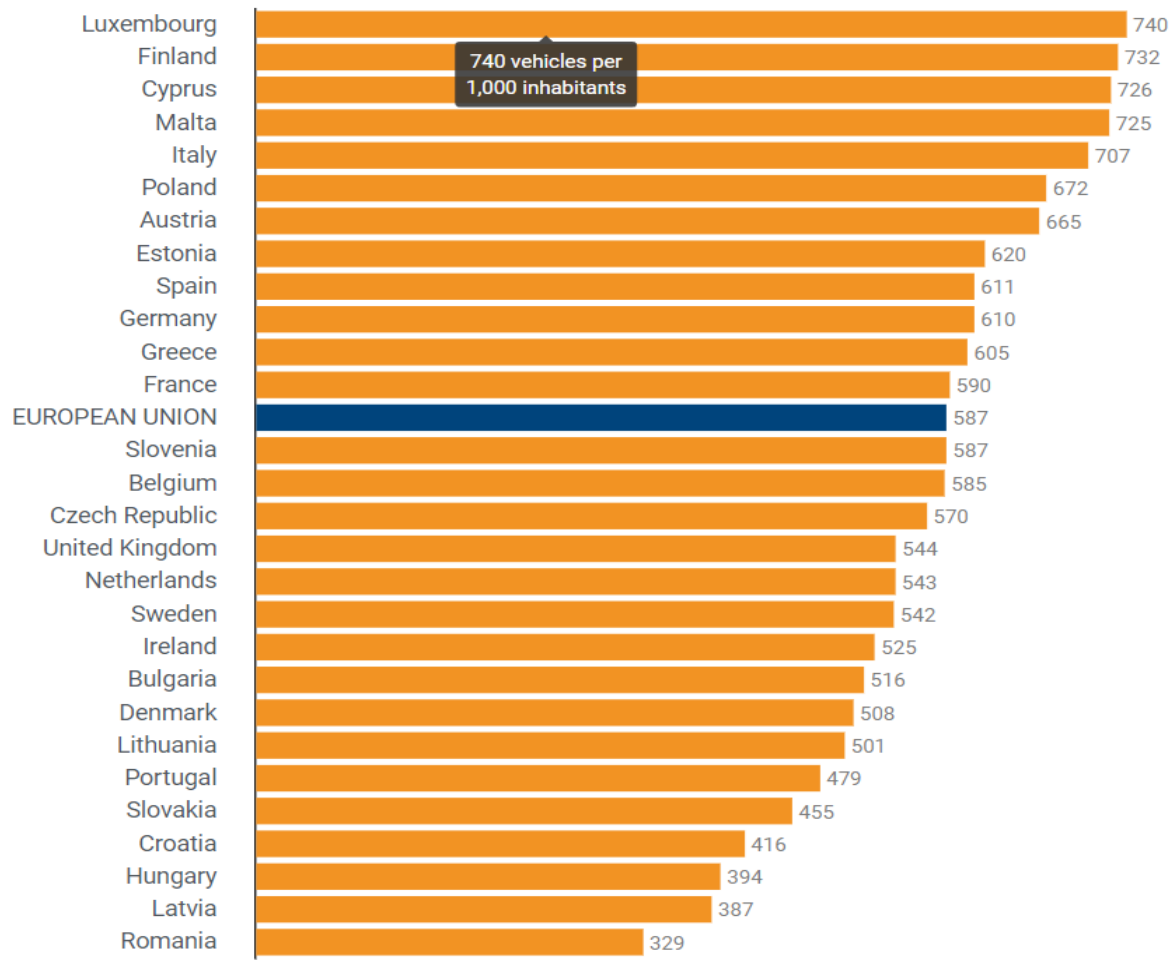

Figure 12: Motorisation rate in the EU in 2016 [21]

Share of alternative fuel vehicles per vehicle segment

- Passenger cars Buses Light commercial vehicles

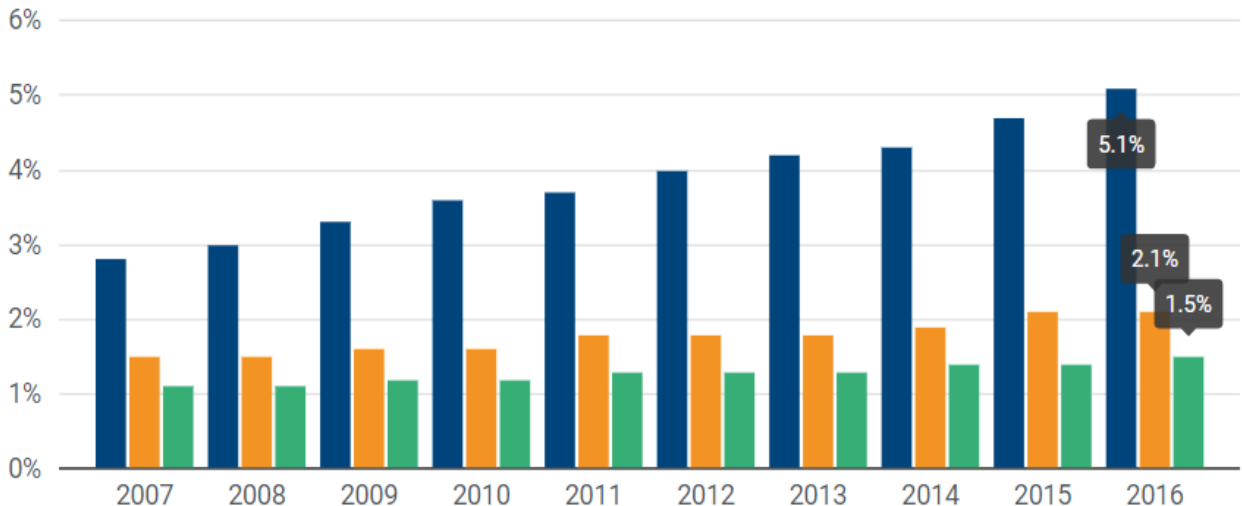

Created with LocalFocus

Figure 13: Share of Alternative fuel in different types of Vehicles [22] 


\subsubsection{Charging of electric vehicles}

The transition to CEVs needs the infrastructure, namely charging stations. There are two things regarding the charging stations: 1) access to charging stations (number of charging station) and 2) time to charge (i.e. power output of the charging stations). These two things need much more attention to make the CEV target successful.

Accessing charging stations is not a big hurdle when considering buying a CEV. Japan for example, now has more charging stations than petrol or gas stations according to Nissan. [23]

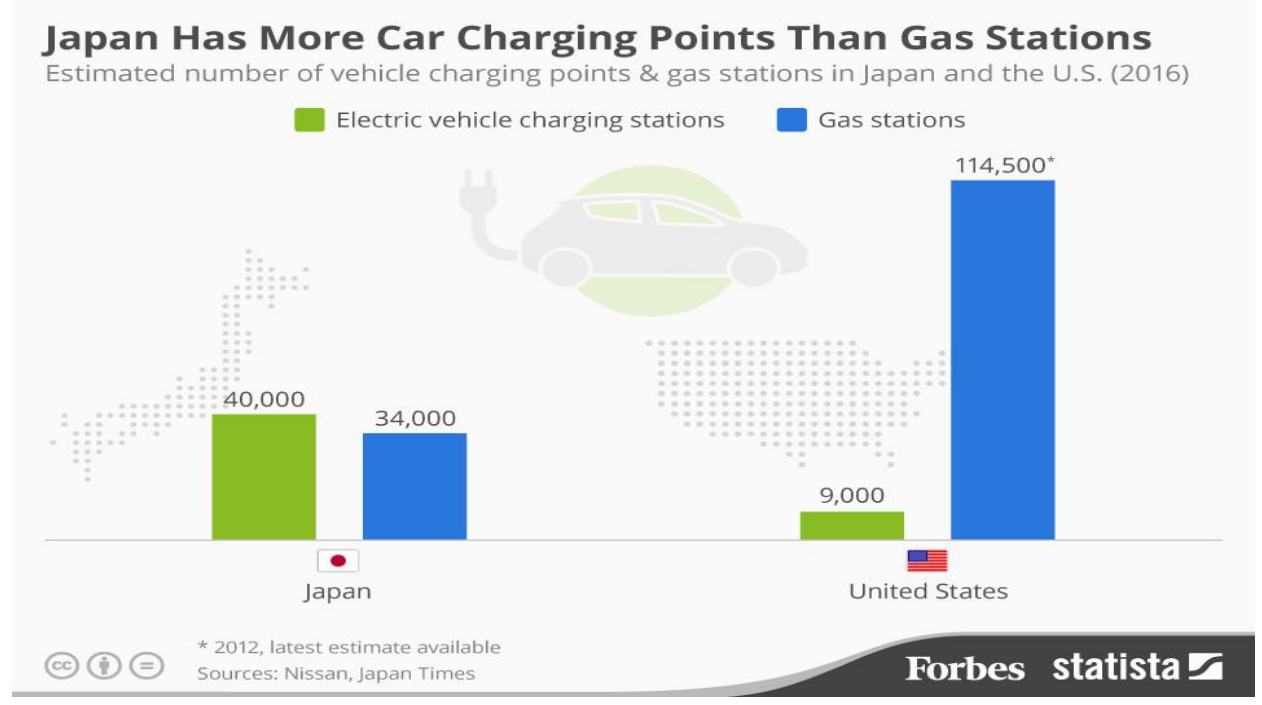

Figure 14: Comparison of Charging and Gas stations in US and Japan [23]

According to the ACEA, the number of charging points in the European Union is roughly 100,000 . But this number is very small when sales of plug-in cars will speed up in the future. Therefore, it must increase at least 20 times to 2 million by 2025 to avoid this hurdle. The ACEA study revealed that the density of charging infrastructure widely varies between countries. Approximately $76 \%$ of all charging points are installed in four countries (the Netherlands, Germany, France and the UK), which covers a land area of only $27 \%$ of the overall area in the EU. [24] 


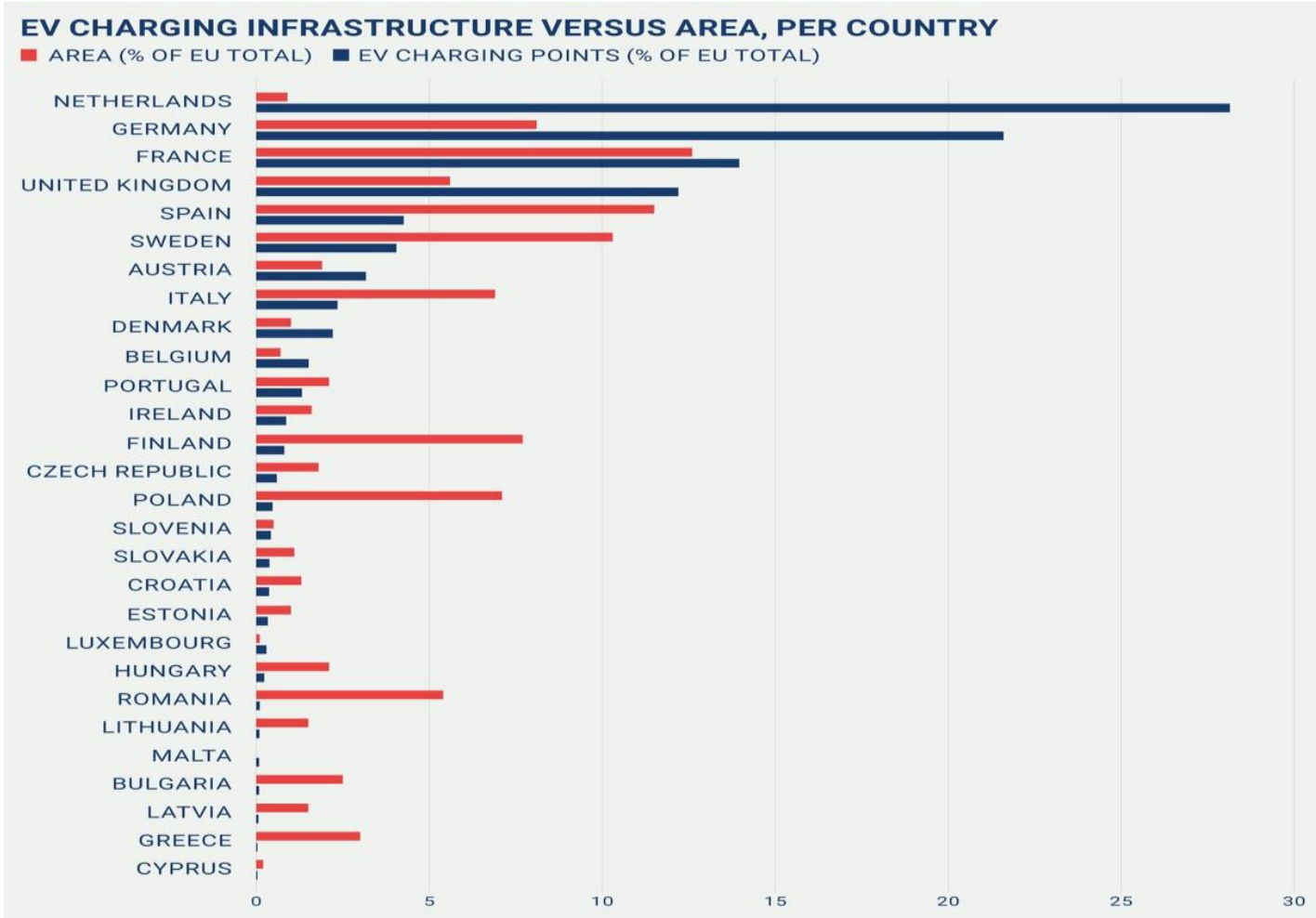

Figure 15: Charging Infrastructure vs Area [24]

\section{DISTRIBUTION OF EV CHARGING POINTS ACROSS THE EU}

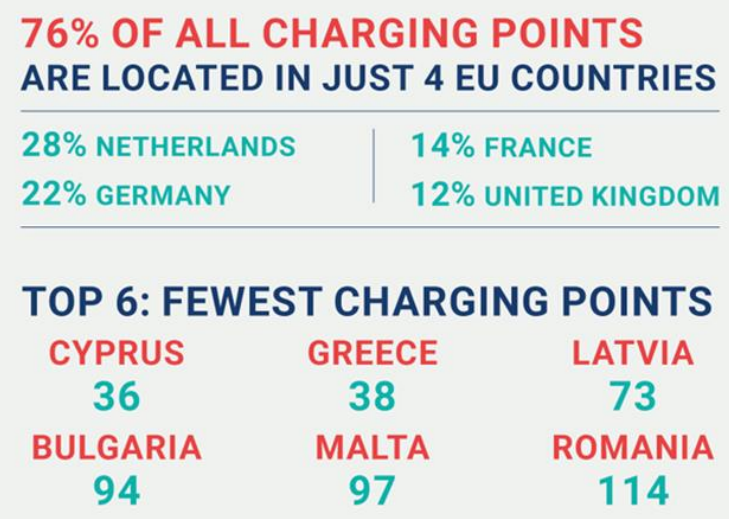




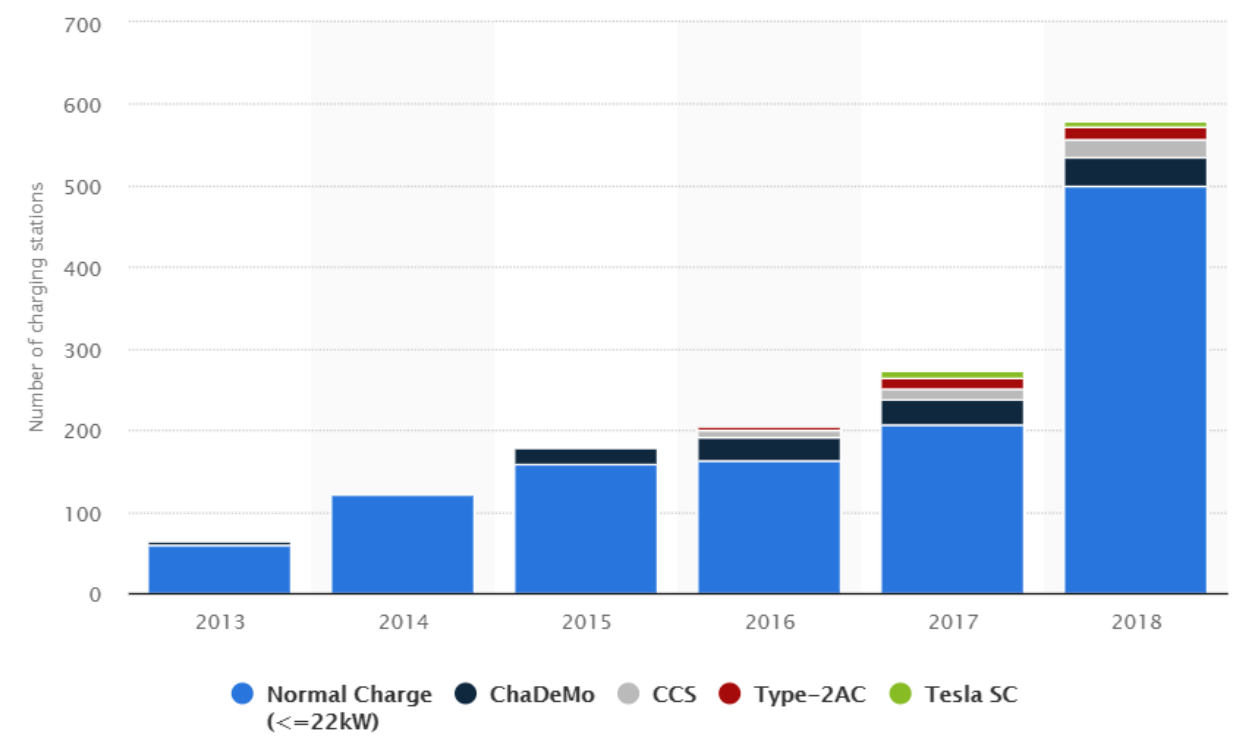

Figure 17: Number and Types of charging stations in Hungary [26]

There are approximately 222 charging stations currently in Budapest. A total of 600 million HUF is planned to be spent on 500 charging points at 250 electric vehicle charging stations which will be opened in Budapest under an agreement between the Ministry for National Economy and the Municipality of Budapest. [27]

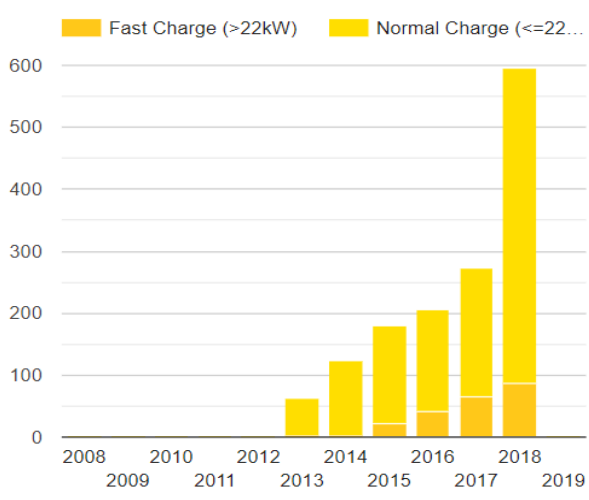

Figure 18: Number of Normal and Fast Charging Points in 2019 [28]

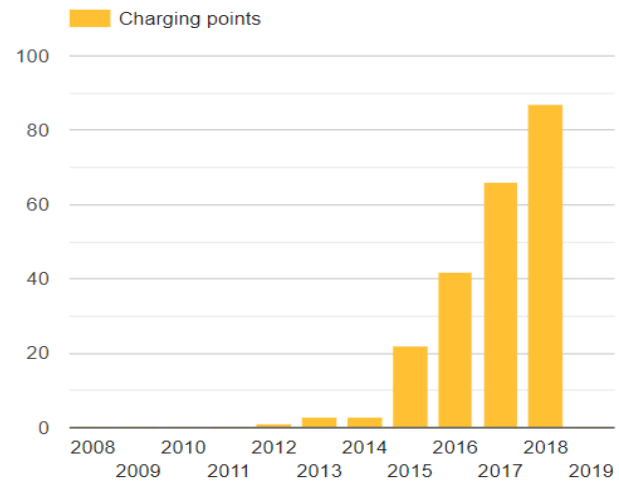

Figure 19: Fast public charging points in 2019 $(>22 \mathrm{~kW})[28]$

The most common power type is $22 \mathrm{~kW}$ followed by $\geq 22 \mathrm{~kW}$ chargers, called fast chargers. 


\subsubsection{Basics of EV charging}

Charging of EVs on the LV grid can cause problems on the grid itself [29]:

- The extra load caused by EV charging can result in overloading of transformers and high voltage drop at the end of a feeder. When the overloading occurs, we need to replace transformers and power cables but these types of equipment are very costly and it is a tough task to replace them.

- Most EVs currently have single-phase chargers, which cause voltage asymmetry on the LV grid.

- EC charging injects harmonic currents into the LV grid, which produces an extra loss in cables and transformers, further reducing their lifetime, as well. 


\subsection{European Power Distribution Grid}

European transformers are three-phase and in the order of 300 to $1000 \mathrm{kVA}$. The EU distribution system connects the house service in its tri-phase characteristics. At the house service connection, the EU grid typically provides a three-phase supply with a separate neutral and earth. Figure 20 shows the typical EU distribution circuit. The line-to-line voltage is $400 \mathrm{~V}$, and the line-to-neutral voltage is $230 \mathrm{~V}$ [30].

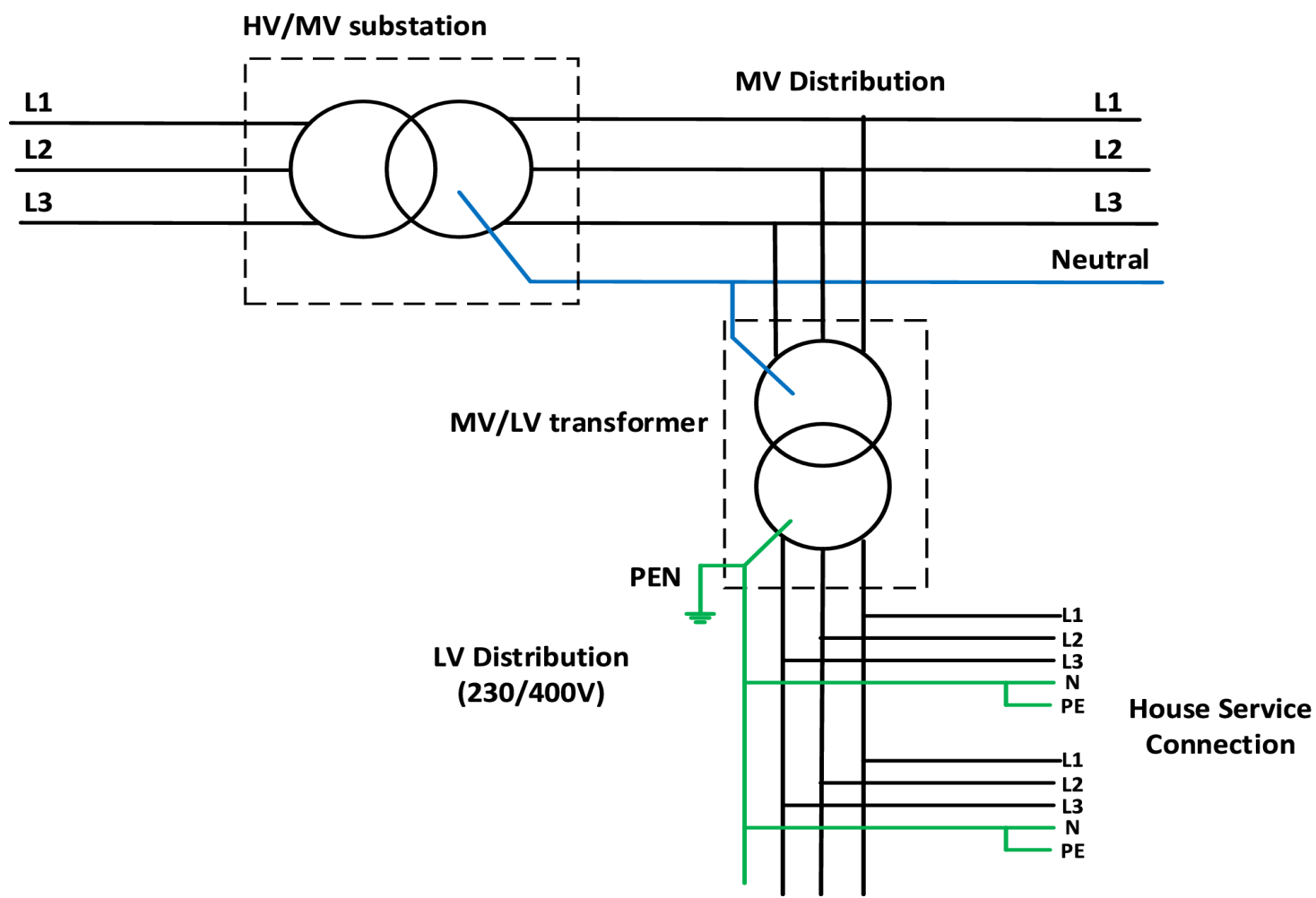

Figure 20: Structure of European power distribution grid [30]

For single-phase EV charging, EV load is connected between one of the phase wires (L1, L2, or L3) and the neutral wire. The connection schemes for these loads is shown in Figure 21. The maximum charging power for the single-phase charging is limited to $4.6 \mathrm{kVA}, 20 \mathrm{~A}$ on $230 \mathrm{~V}[30]$. 


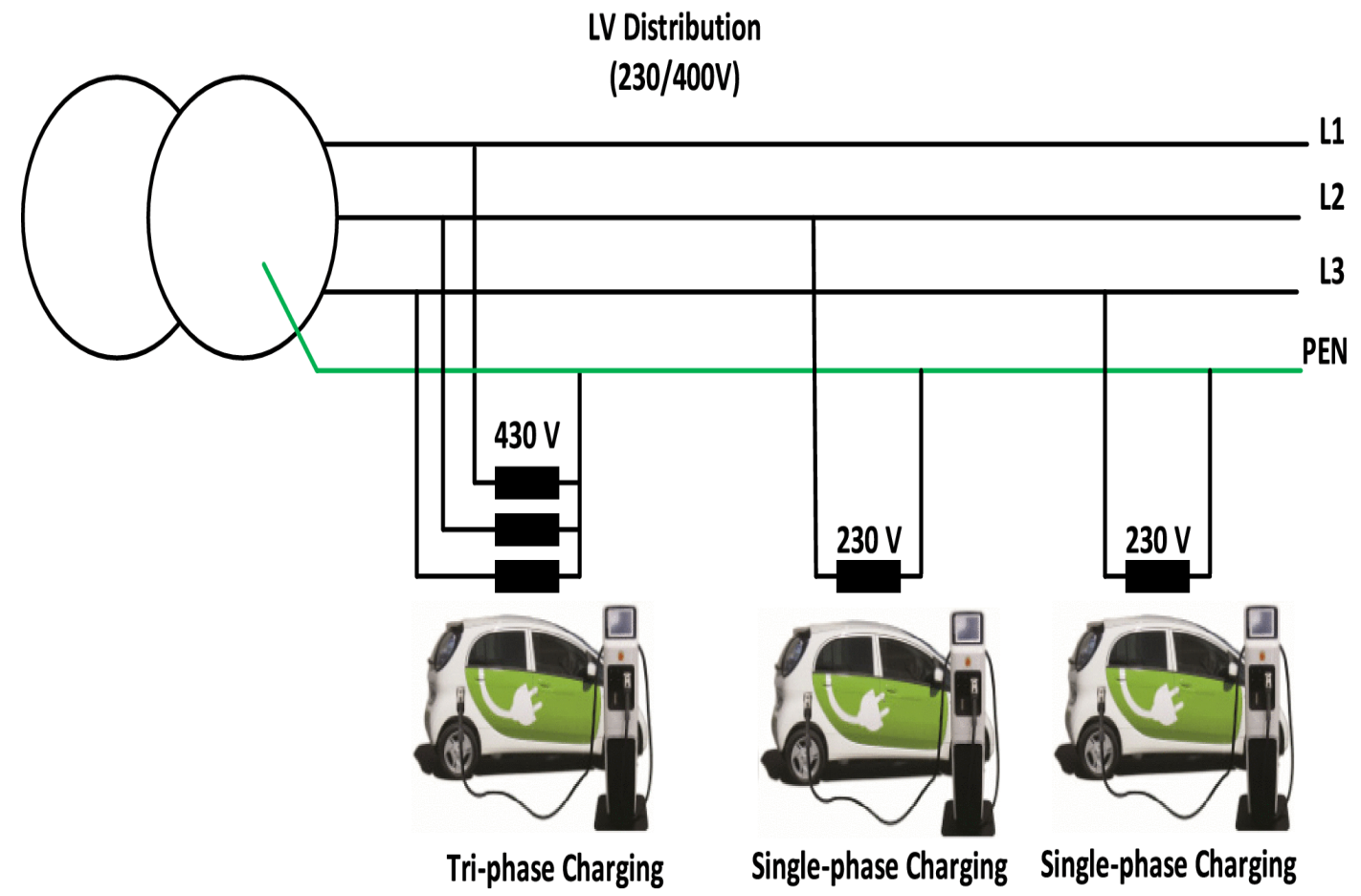

Figure 21: EV connection schemes in Europe [30] 


\subsubsection{The Electric Grid in Hungary}

The electric grid is an interconnected network for delivering electricity from producers to consumers. Hungary has electricity high-voltage transmission lines of 750 kilovolts $(\mathrm{kV})$, $400 \mathrm{kV}$, and $220 \mathrm{kV}$; these measures approximately 270, 1,730, and 1,200 kilometres in overall length, respectively. There is also a $120 \mathrm{kV}$ grid which is directly supplied by many of Hungary's power plants, including the Paks nuclear power plant [31]. Hungary's higher voltage electricity transmission grid is shown in Figure 22.

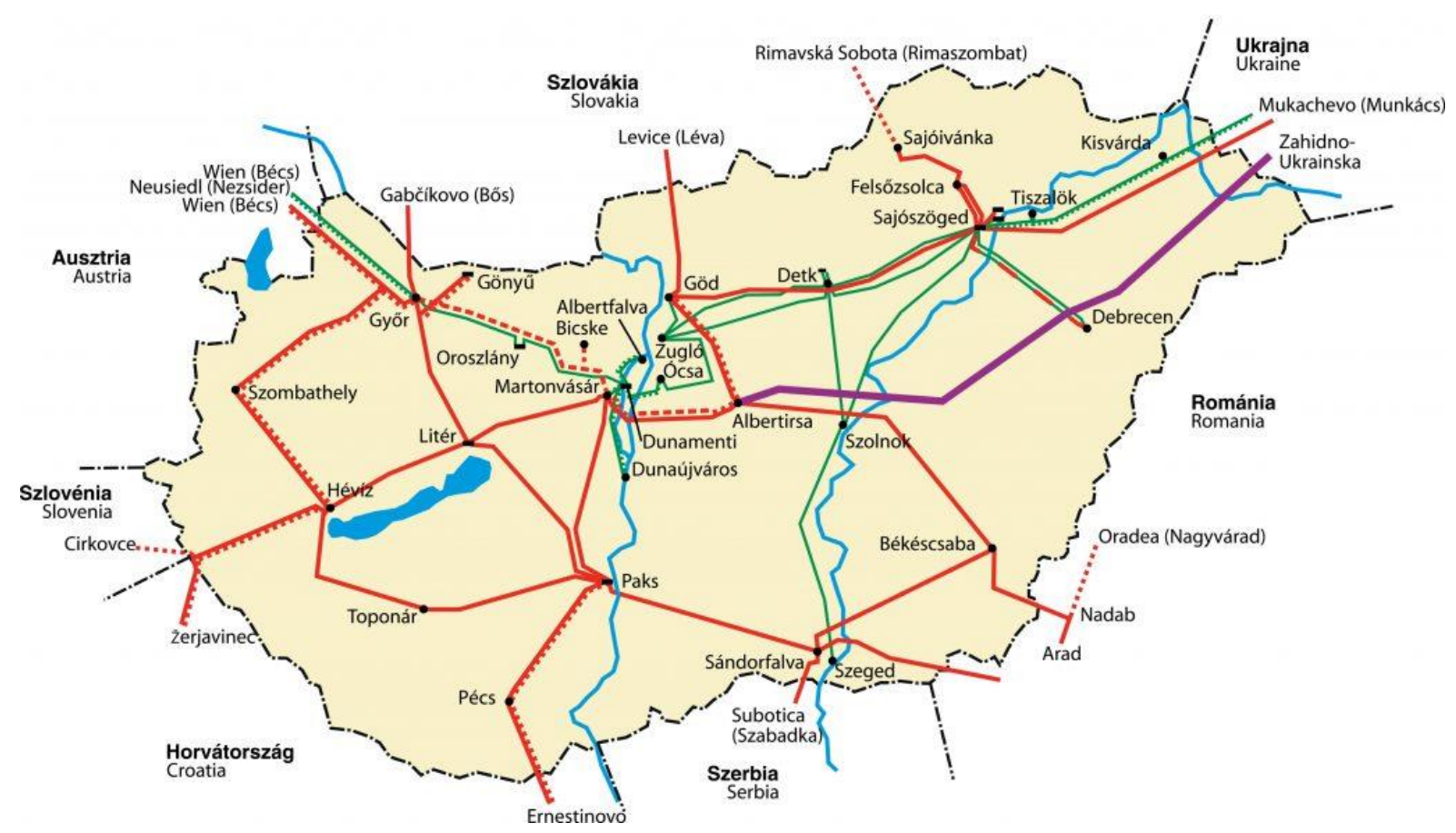

Figure 22: National Electricity Transmission Grid of Hungary [32]

The Hungarian electricity supply industry consists of 12 generating companies and six distribution and supply companies. The high-voltage transmission network is owned by MVM Rt., the country's state-owned incumbent monopoly power supplier [33]. The grid in Figure 23 is divided into transmission grid and distribution grid. The distribution grid in Hungary is like local grid, where the transmission grid both consists of regional grid $(120 \mathrm{kV})$ and national grid (220-400-750 kV). The voltage level shown in Figure 23 is for Germany and other European countries [34]. 


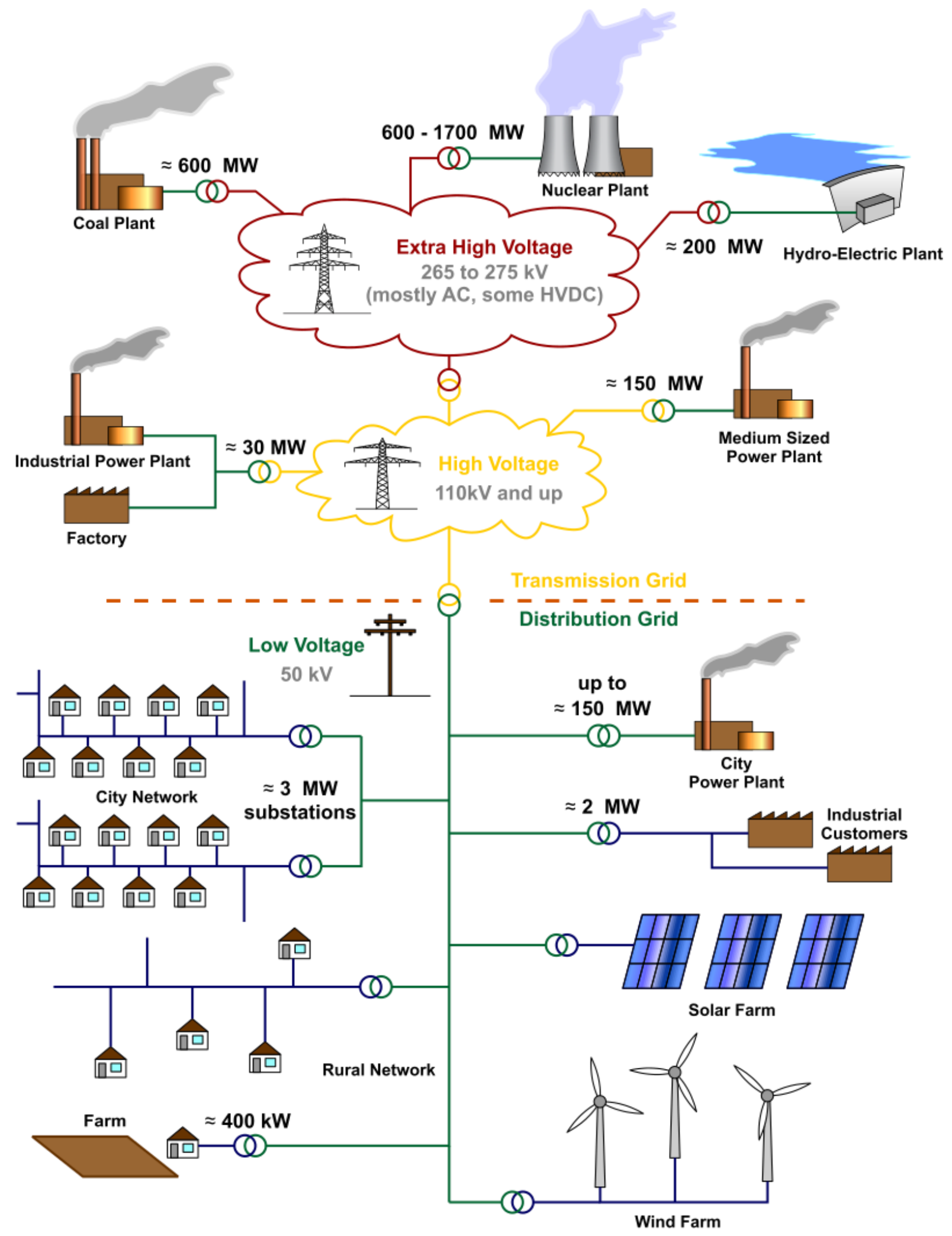

Figure 23:Electricity Network Layout for EU [34] 


\subsubsection{Current Load}

Traditionally, the household load of consumed electricity has a relatively consistent pattern. People wake up, turn on e.g. their coffee maker and the load increases, go to work and the load decreases, come home and start to cook food and turn on other electric appliances which makes the load increase again, and then they go to sleep and the load decreases. The household load is driven by human behaviour and other factors such as the weather (especially affecting the need for heating).

\subsubsection{Hungary}

TSCNET shareholder MAVIR, the Hungarian transmission system operator (TSO), faced a national electricity consumption on a record level in 2017. The total annual electricity consumption amounted to 45,057.4 GWh according to preliminary data from MAVIR without considering solar microgeneration. This was $2.6 \%$ higher than in 2016 . The total consumption of energy i.e. 146.87GWh in a day, a historical peak, was observed on 27 January 2017. [35]

The TSO was able to meet the demand without interruptions however the Hungarian transmission system in 2017 was exposed to temporary extreme weather conditions, occasionally causing physical damage to network elements. [35]

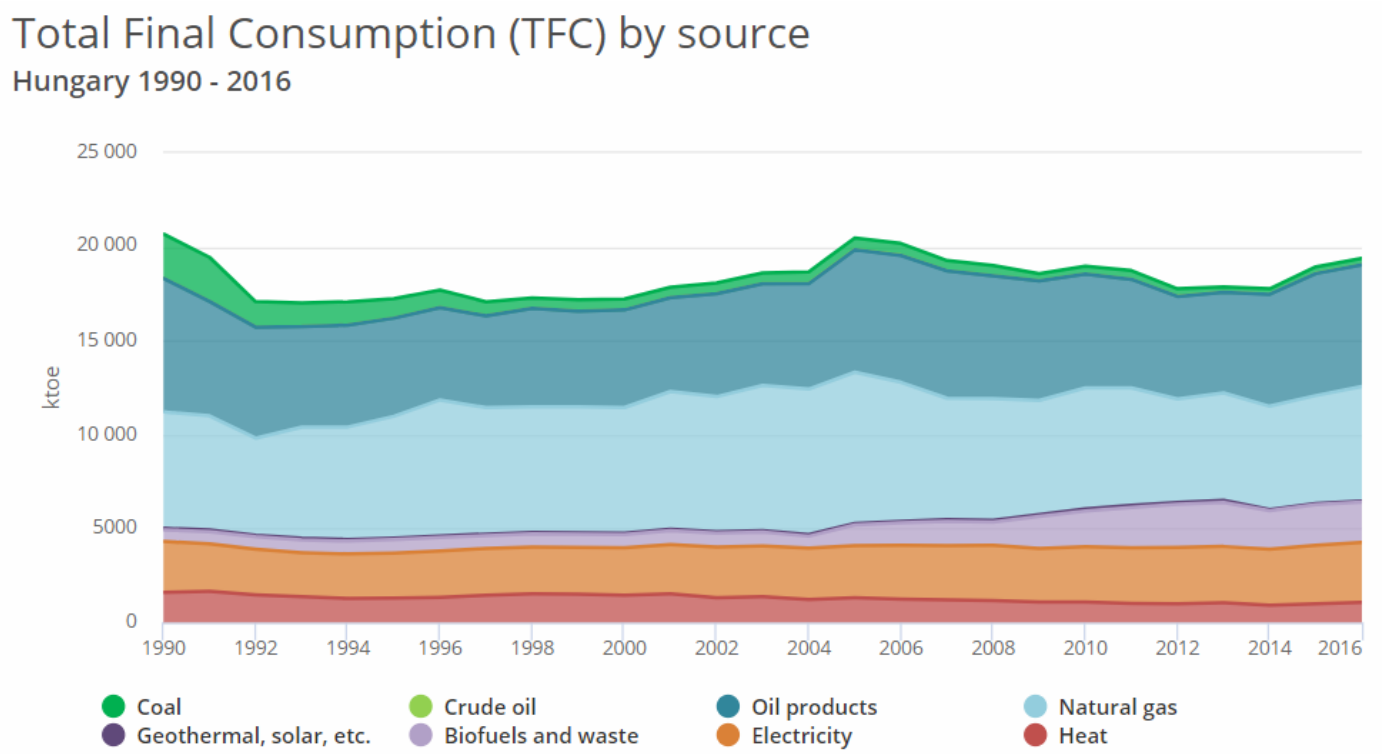

Figure 24: Energy consumption in Hungary [36] 


\subsubsection{Budapest}

As already mentioned above, the number of electric cars is more than 9000 in Hungary and much of them are present in the capital city, Budapest. We know that the EVs loading is going to increase in the future very rapidly, it might impact on the grid due to excessive loading. Therefore, we need to manage the loads of a metropolitan city so that it will not cause problems in future.

\subsubsection{Future Load}

The electricity usage is broken down in three major segments, Housing and Service, Industry and Transport. Since this report is about how the electricity load in households will be affected by EVs growth, the predicted electricity usage in the Housing and Service segment is also interesting in that how much other loads are affecting the grid. It is necessary to know about every loads in the grid so that we can tackle the adverse impact of EVs on the grid. 


\subsection{Impact of EVs on the LV Grid and its Mitigation}

Several challenges for the existing grid are posed by the growing EV charging infrastructure. It is observed that EV charging during peak load hours may increase the peak load demand and cause the expansion of generation capacity. In addition, increased load demand may overload substation and service transformers, thus deteriorating the transformers' life. Furthermore, EV charging may result in several power quality issues such as unnecessary voltage drops in the secondary service voltages, power imbalances, and voltage/current harmonics.

\subsubsection{EV load impacts on Electricity Generation}

It is very necessary to analyze the existing and planned generation capacity to meet current and future EV demands. If EVs are charged during off-peak load hours, new power plants will not be required to meet EV charging demand. If we control and shift EVs charging off-peak hours, it will not increase the system peak load demand. Hence, it will not affect power generation adequacy, however, large-scale EV deployment could decrease supply adequacy without controlled charging. Therefore, it will need the construction of additional power plants in this case. [30]

\subsubsection{EV load impacts on transformer loading}

Large-scale EV deployment can cause increased load demand, increased system losses, and additional voltage drops in the grid. The increased load demand due to EV loads can overload service transformers, deteriorate the service transformers' life, and increase system losses. EV charging creates new load peaks that can exceed the rated capacity of service transformer, hence accelerating equipment ageing. However, if EVs are primarily charged during off-peak hours, it can reduce the daily expansion and contraction of the transformer due to flattering load profiles, resulting in a positive effect on the transformer's life. [30] 


\subsubsection{EV load impacts on Power Quality}

EV charging is also likely to cause power quality problems in the grid such as under-voltage conditions, power imbalances, and voltage and current harmonics. When the number of EVs increase, more electricity demand is required to charge their batteries. For example, the LevelII charger consumes double power than Level-I to charge the EV. This increased load demand leads to additional voltage drops in the secondary service voltages, thus affecting the service voltage quality. [30]

\subsubsection{Time-of-Use (TOU) pricing to mitigate EV load impacts}

The EV impacts analysis concludes that during peak load hours EV load charging can lead to an increase in the peak load demand and under-voltage conditions, thus needing grid expansions and upgrades. The penetration of EV loads into the distribution grid depends upon the uncontrolled charging of EVs. Utility companies implement a TOU pricing structure to avoid EV charging during peak load hours. The electricity usage is rated differently during peak (higher rate) and off-peak hours (lower rate) in this scheme. That's why it motivates the customers to charge their vehicles during off-peak hours. By using this scheme, load demand profile can be flattened to reduce the load during peak hours. [30]

LOWEST COST

IDEAL CHARGING TIMES: 11PM - 7AM

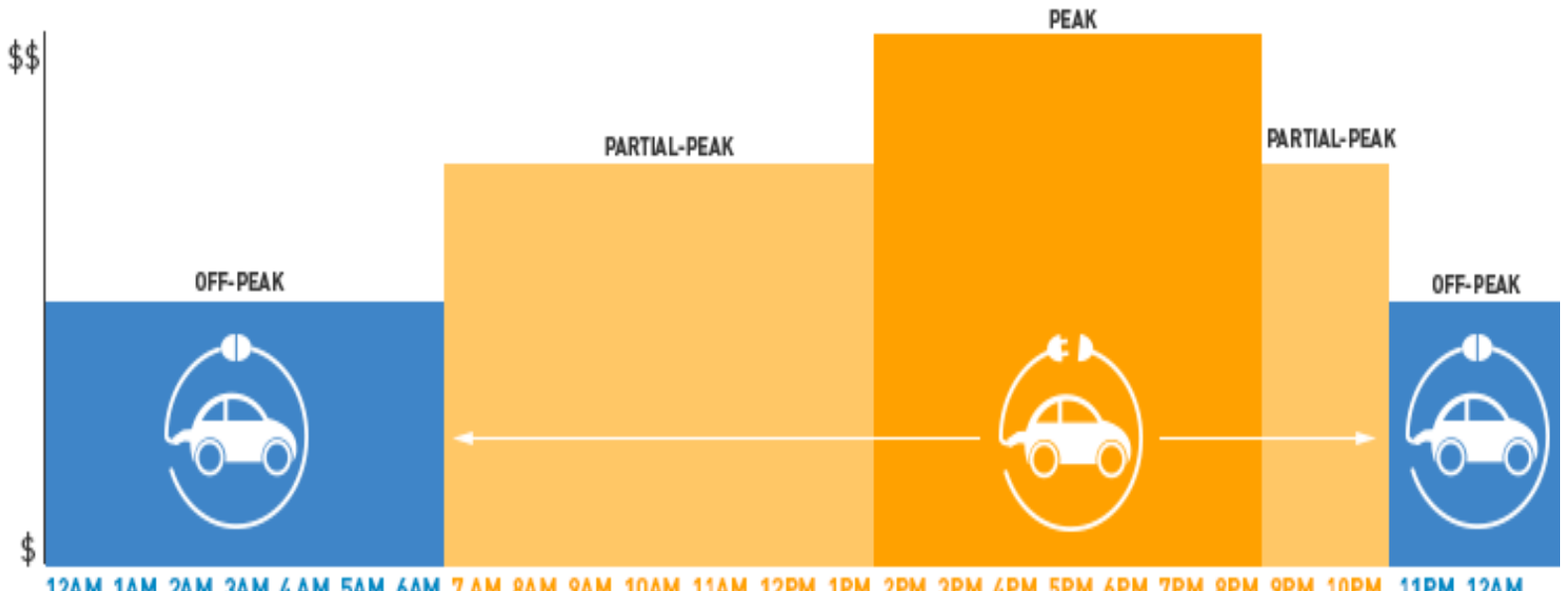

Figure 25: EV Charging Rates [37]

In Figure 25, we observe that the charging rates are higher between 7AM to 11PM and the ideal time to charge EV is from 11PM to 7AM. 


\subsubsection{Smart charging algorithms to mitigate EV load impacts}

The TOU pricing structure is not an optimal solution for higher levels of EV penetration because it can create a second peak in load demand during off-peak hours and this will essentially limit the number of EVs. A significant amount of power system capacity remains underutilized due to the simultaneous charging of all EV loads in the TOU scheme. Controlling of EV charging rate and charging start time to optimize the desired grid objective can be more efficient to the power system. The desired grid objective includes flattening the overall load profile, minimizing the charging cost or losses. Therefore, smart charging algorithms are developed which can accommodate higher percentages of EVs into the grid without causing negative impacts on the distribution feeders. Some of the algorithms are dynamic programming algorithms, quadratic programming, stochastic programming, etc. [30]

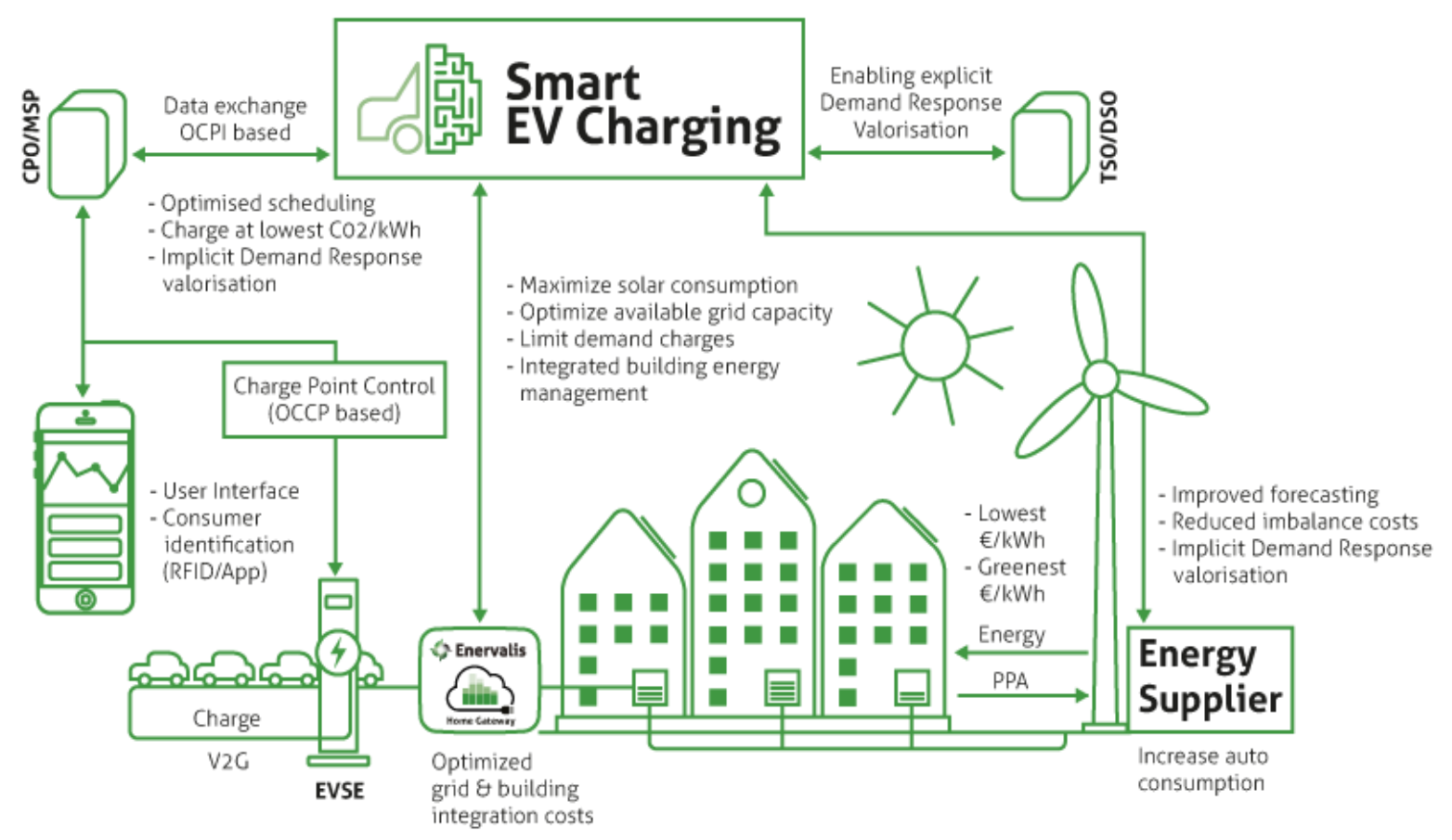

Figure 26: Smart EV Charging [38]

Figure 26 shows the block diagram of smart EV charging which predicts the needed energy and departure time of the EV-driver based on historical charging patterns while taking into account the local grid constraints. 


\section{Impacts of electric car charging on LV grid}

This section presents the chosen methodology used in this thesis. It includes the description of the research approach and the research process and presents the chosen data sources and the modelling method.

\subsection{Research approach}

The purpose and aim of this thesis is to study and analyze the possible impacts electric cars might have on low-voltage grids, to create LV grid models in DigSilent Power Factory to conduct asymmetric load-flow simulations with taking the variation of household loads, car home arrivals, different state-of-charge, etc. into consideration and to evaluate the obtained results. To do it, we have taken a small residential area to create the necessary low voltage grid model for simulation and run the load flow analysis and time sweep analysis.

\subsection{Research process}

The reason for this thesis topic is the interest in the chargeable electric vehicles which is growing in number very rapidly and to know the impact they can have on low-voltage grids. The companies wanted a better understanding of how CEVs affect them as grid owners in the future and what actions they can take to tackle these problems. That's why we have firstly defined the problems what objectives we have as stated above, then structured the problems like we have added some households loads and few electric cars and analyze the load flow and time sweep analysis to find out the loading on transformer, variations in voltage, current, etc. across each load and car.

\subsection{Collection of data}

As mentioned above, an important part of this thesis is identifying and taking the appropriate data. For accurate information of how this will impact the grid, it is very necessary to know the estimation of how many CEVs there will be in future and where they will be used and what technical specifications they have.

Determining these things is a very difficult task and time-consuming. We have taken small grid near the university and small number of household loads and electric car loads i.e. in my case 46 households loads and 12 electric car loads. 
For gathering data, it is very important to know how people in Hungary and Budapest are using their cars which we have discussed in literature review and how the usage of cars will affect the grid when replaced by chargeable electric vehicles.

\subsection{The investigated grid}

We need to find the data about the local electric grid which we used for our thesis in areas near the university, to understand the components of the grid and how it works. We also need to know how the grid is constructed and how the different components interact with one another and understand how the grid load is today and how it might change.

\subsubsection{Phase assignment}

The household loads in the grid are single-phase loads, thus they operate on $230 \mathrm{~V}$ line to ground. Since loads are connected to different phases, there will be voltage asymmetry in the network. If all the consumers are three-phase loads, there will be no asymmetry at all. The only asymmetry comes from the electric car chargers then.

\subsubsection{Grid parameters}

We don't know the value of other electrical parameters (such as resistance, the reactance of cables), therefore, we used the built-in cable, transformer, etc. types of the DigSilent Power Factory Software which contain all the necessary information. We used the transformer with nominal power of 0.63 MVA and have the vector group Dynl-4.

\subsubsection{Power factor of loads}

Power factor is a measure of how effectively we are using electricity. The power factor is chosen to be 0.9 for households and 1 for electric car loads. The power factor is likely to change with changing loads.

\subsubsection{Travel Behaviour}

The distance covered by the electric cars can be treated as a random variable. People usually go to their destination and spend their daytime and they come back home in the evening or at night. Most of the car charging took place between 6 PM to 7 AM. 


\subsection{Grid implementation}

This section discusses the parameters of the chosen grid and model the grid in the DigSilent Powerfactory software. It also explains the chosen data i.e. active power, power factor for household loads and electric car loads.

\subsubsection{Parameters}

The chosen transformer is of $630 \mathrm{kVA}$ nominal power. The built-in Dyn1 4 ASEA transformer is used for this purpose. The length and the cross-section of the cables were known. We used the built-in cables NAYRY $4 \times 240 \mathrm{sm} 0.6 / 1 \mathrm{kV}$ with neutral connected.

\subsubsection{Modelling the grid in the software}

The LV grid is connected through the above-mentioned transformer. An external grid with 10 $\mathrm{kV}$ line to line is connected to the grid. We have modelled the supply area of transformer no. 800 [39]. Figure 27 depicts the network topology and the type of cables.

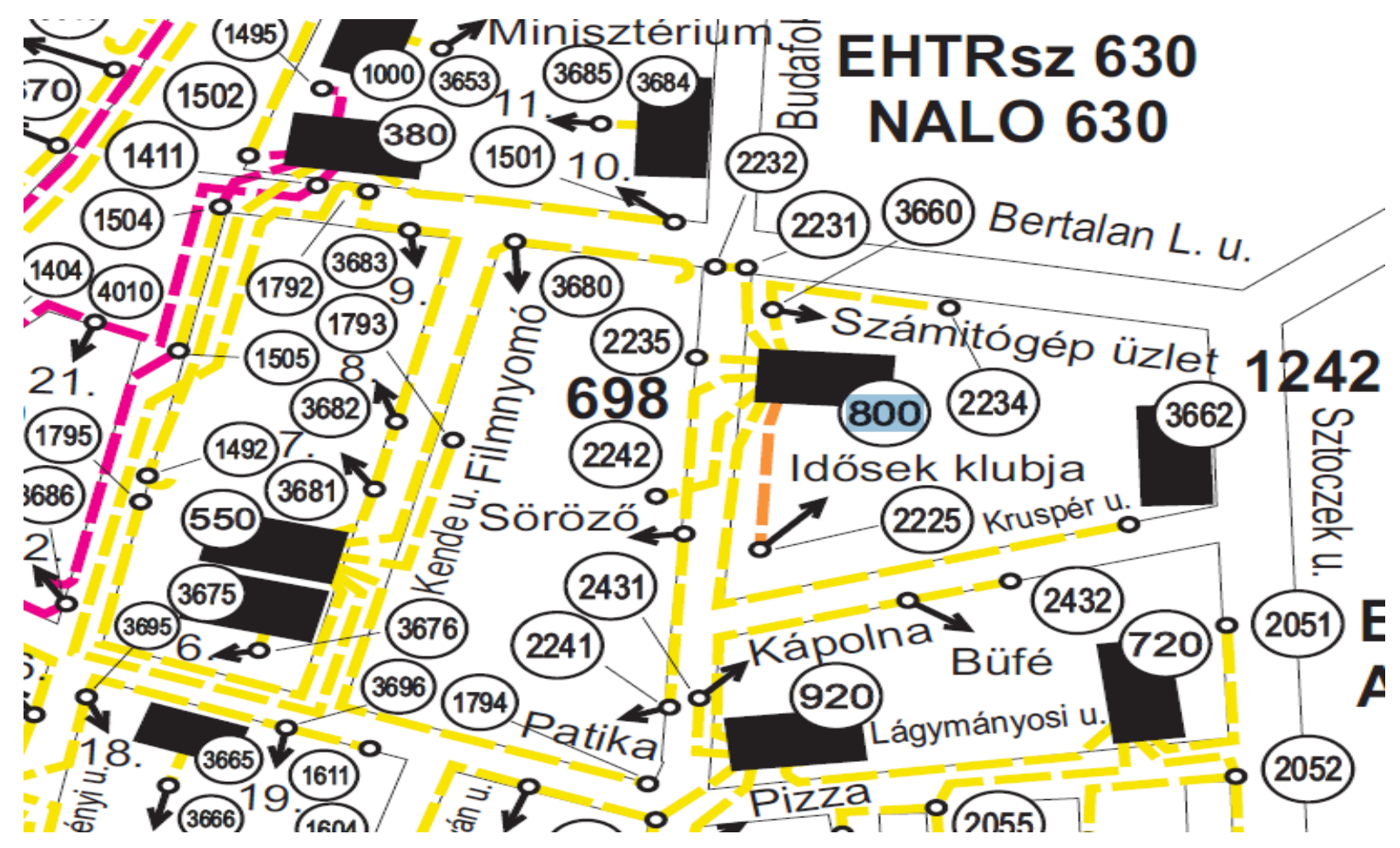

Figure 27: Network Topology [39] 


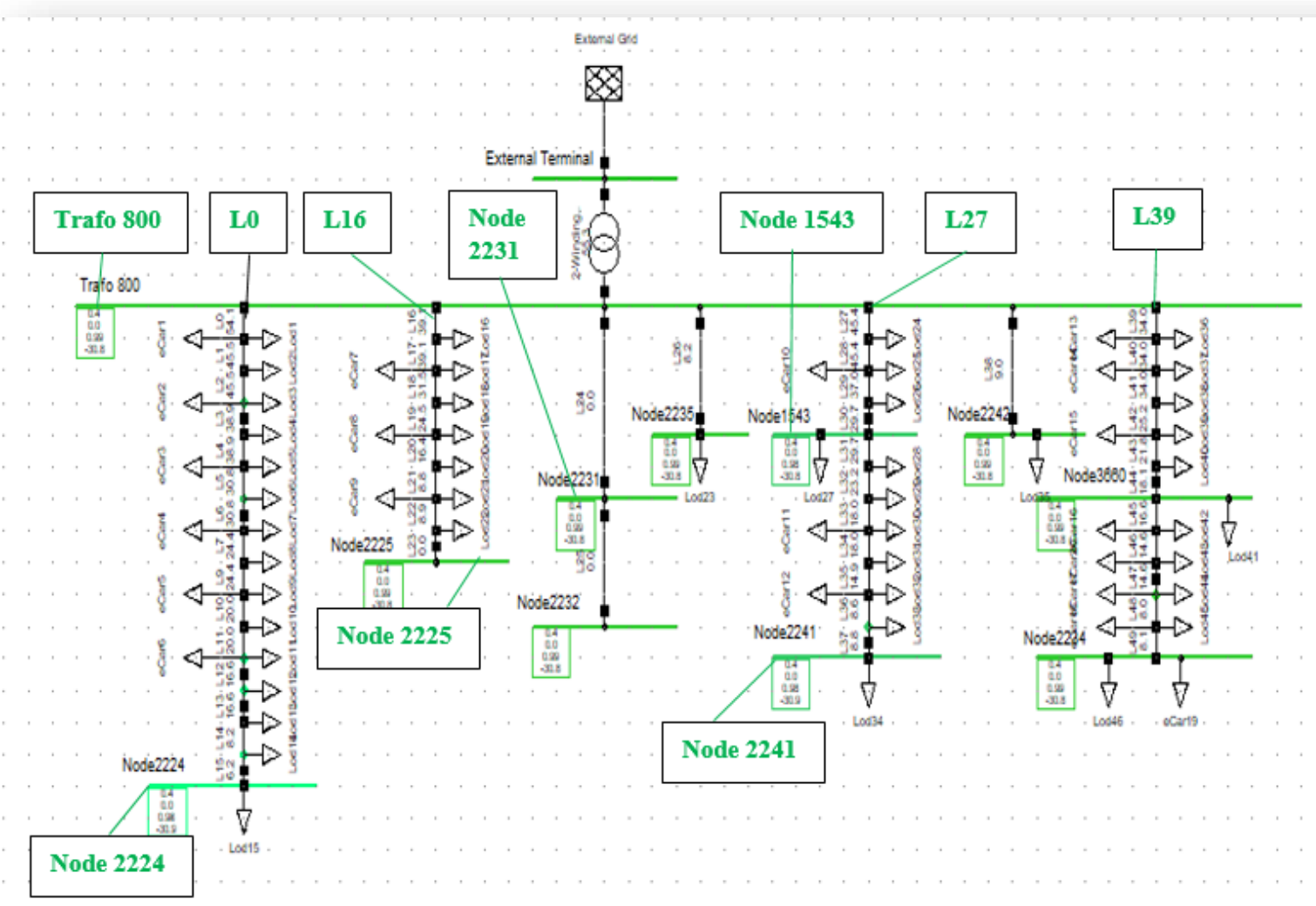

Figure 28: Implemented Grid

The implemented model in DigSilent is shown in Figure 28. The LV networks are operated with neutral. Every load is connected between a phase and the neutral. In the implemented grid, the loads are placed evenly on the cables but in reality, the length of cables vary from a few meters to a few hundred meters.

After running the time sweep simulations, we have plotted different parameters i.e. the loading of the transformer [\%], the voltage of the different busbar [pu] and the current loading [\%].

\subsubsection{Household load profiles}

The variation in electrical load versus time is shown in Figure 29. In the evening, the load is very high because people from work return to their home and use most of the electrical equipment. On the other hand, people sleep and factories \& industries do not run in the night. Hence they don't use electrical equipment, therefore, the minimum loading is between $10 \mathrm{pm}$ to $6 \mathrm{am}$. It also depends on the weather i.e. the load is high in winter as compared to the summer. 


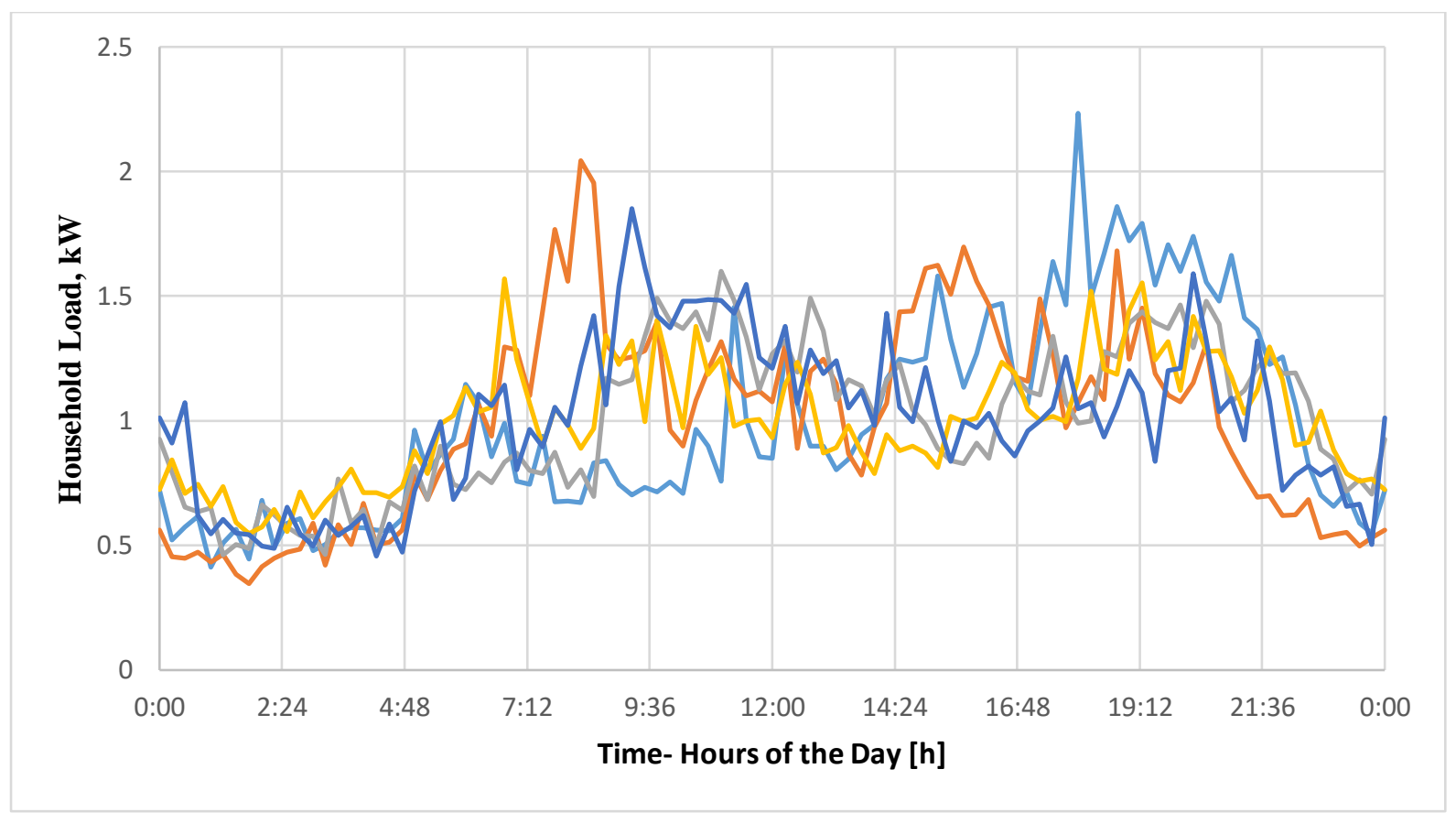

Figure 29: Load charateristics

\subsubsection{Modelling the electric cars connected to the network}

The electric car is added to the grid to the same point with household loads. The maximum load of the household profiles and electric car profiles is $2.8 \mathrm{~kW}$ and $3.7 \mathrm{~kW}$ respectively. For electric car load, we have taken data in such a way that $12 \%$ of electric cars arrive home and start charging at 19:00 and 23:00. And similarly, 20\%, 28\% and 40\% of cars arrive home and start charging at 19:30, 20:00 and 20:30 respectively which is shown in Figure 31.

\subsubsection{EV charging profiles}

A People usually travel by car during day time. People return to their home and charge their vehicles in the night, therefore, the load is very high during this time. Figure 30 shows the charging profile of electric cars. In one case, the charging takes place from $5 \mathrm{pm}$ to $1 \mathrm{am}$ and in another case, the the charging is done between $6 \mathrm{pm}$ to $9 \mathrm{am}$. The peak load also depends upon the power consumption of different cars because some cars have high power ratings and some less. 


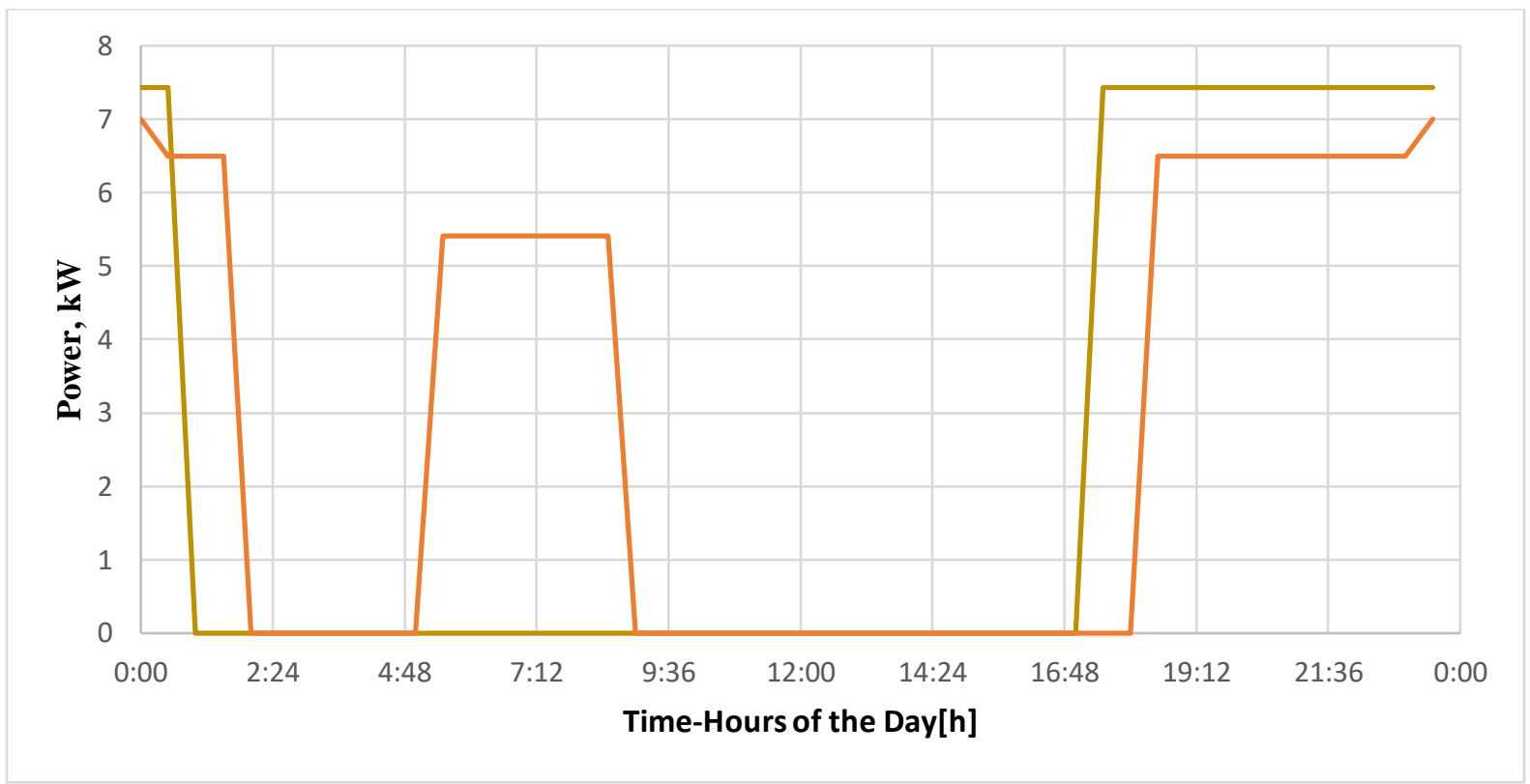

Figure 30: EV charging characteristics

Figure 31 shows the distribution of arrival of cars for charging which we assumed. We can see that $40 \%$ cars arrive between 8:30 pm to $9: 30 \mathrm{pm}, 28 \%$ cars arrives between 8:00 pm to 8:30 pm and 9:30 pm to 10:00 pm. During 7:30 pm to 8:00 pm and 10:00 pm to 10:30 pm, 20\% cars arrive to charge and rest of the cars arrives between 7:00 pm to 7:30 pm and 10:30 pm to 11:00 pm. In this work, the arrival time of all the cars is between 7:00 pm to 11:00 pm.

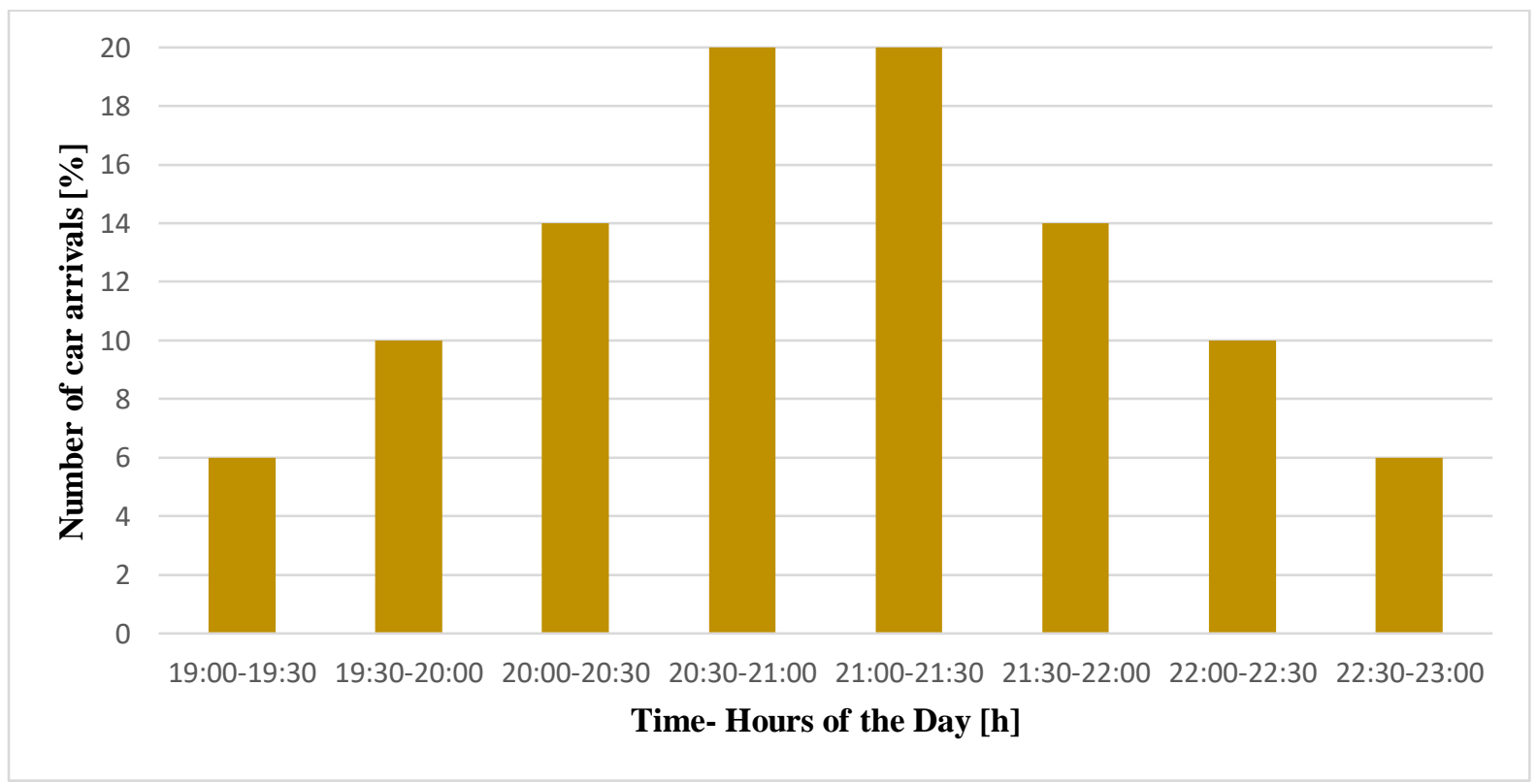

Figure 31: Distribution of the number of cars arriving to charge 


\section{Simulation Results}

Simulations have been carried out using the DigSilent Powerfactory software where it performs the load flow calculations, time sweep analysis. We also have set the resolution of 30 minutes discrete time interval for load flow data algorithm.

The base active power and power factor of each household load are taken $2.8 \mathrm{~kW}$ and 0.9 respectively. Multiple loads are aggregated into one. This load is set in excel file as input for DigSilent. For an electric car, the base active power is taken as $3.7 \mathrm{~kW}$ and power factor is set as 0.85 inductive. It is used as input for DigSilent.

\subsection{Python Scripting}

We used python scripting to decrease the complexity in scenarios management and result analysis when there will be a huge number of electric vehicles to charge in future. This complexity is high when dealing with modern smart grids. Comparing and analysing the obtained simulation results can be a repetitive and tedious task that is better carried out with the help of some automation mechanism, such as a scripting language [40]. The python API provided with digsilent powerfactory is a great asset when it comes to automating simulated related tasks.

We run the unbalanced load flow because electric car load is a single-phase load. The arrival and departure of an electric car are chosen according to the distribution depicted in Figure 31, therefore, there will always be the different magnitude of currents and phase differences and also sum of these currents at neutral point will not be zero. Voltage dependency of the load is also considered.

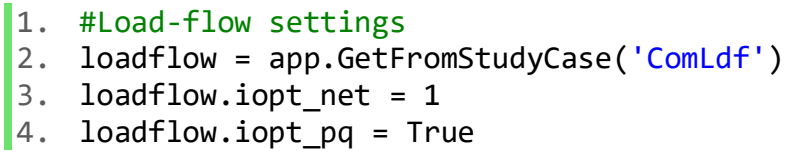

After that, we have created new profiles for the households and cars and set the time characteristics like usage, source, address, file unit etc. The code is run 10 times to analyse the results of how they change in small interval time.

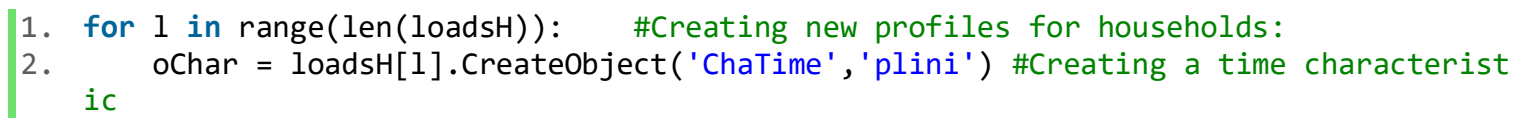




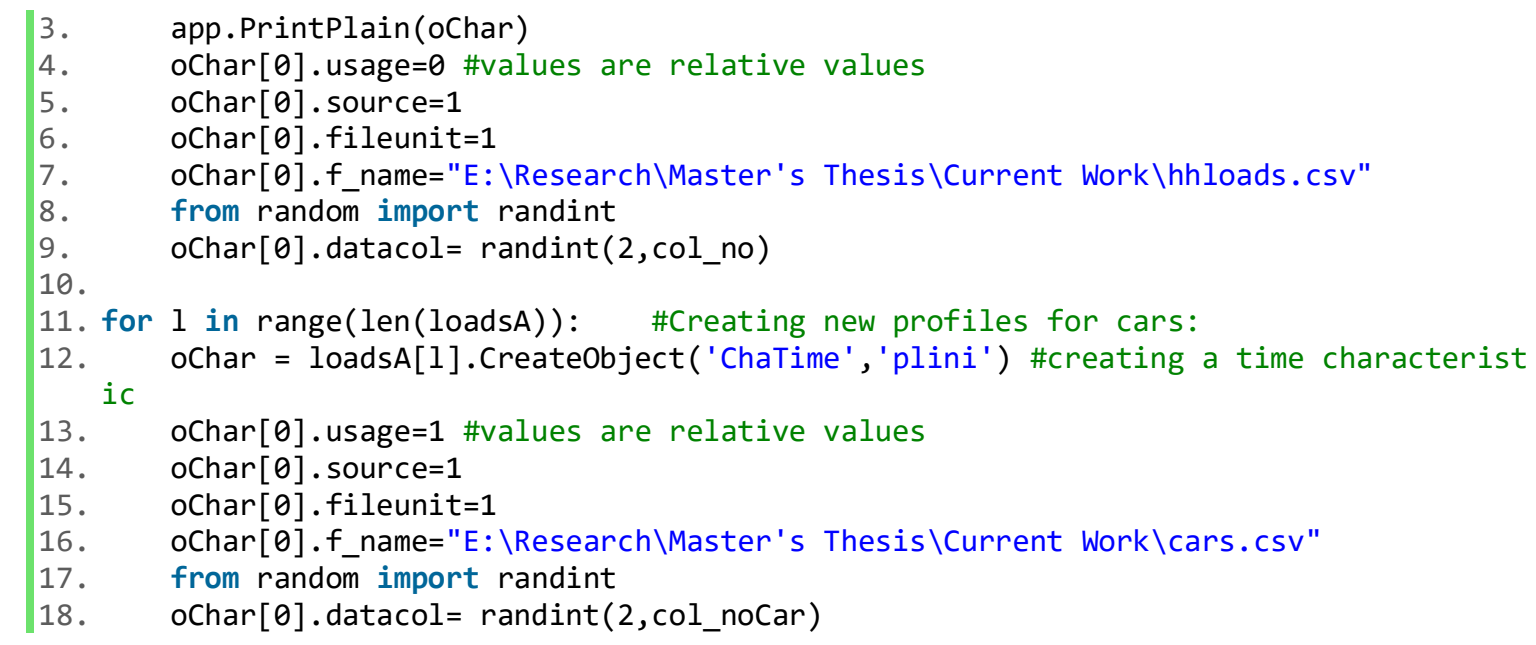

The base active power of each household load and an electric car are taken $2.8 \mathrm{~kW}$ and $3.7 \mathrm{~kW}$ respectively. Below program code set the power and some Gaussian noise for household and electric car loads.

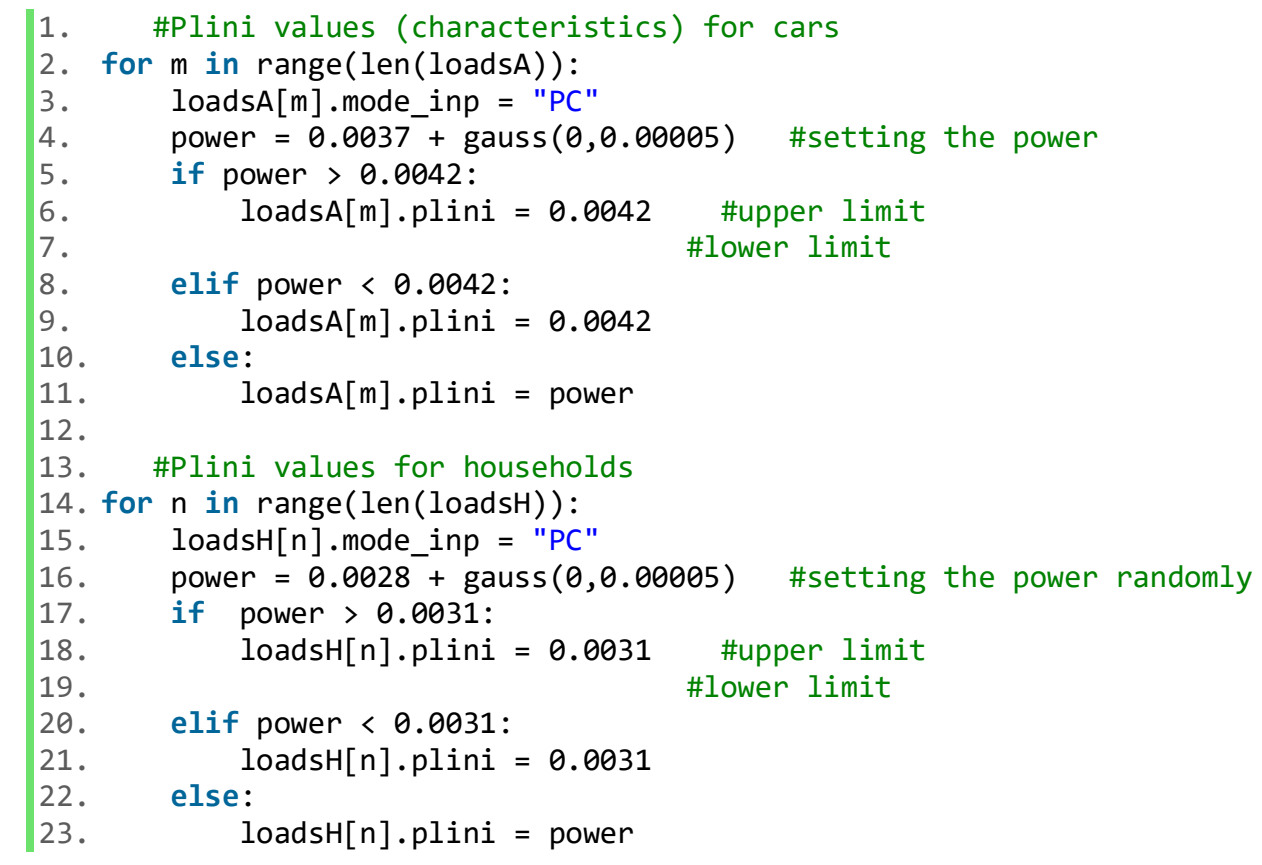

Power factor is the very important parameter for any type of load and we have taken the value of 0.9 and 0.85 and some gauss noise for household loads and cars respectively. After setting all these values we executed the TimeSweep script. 


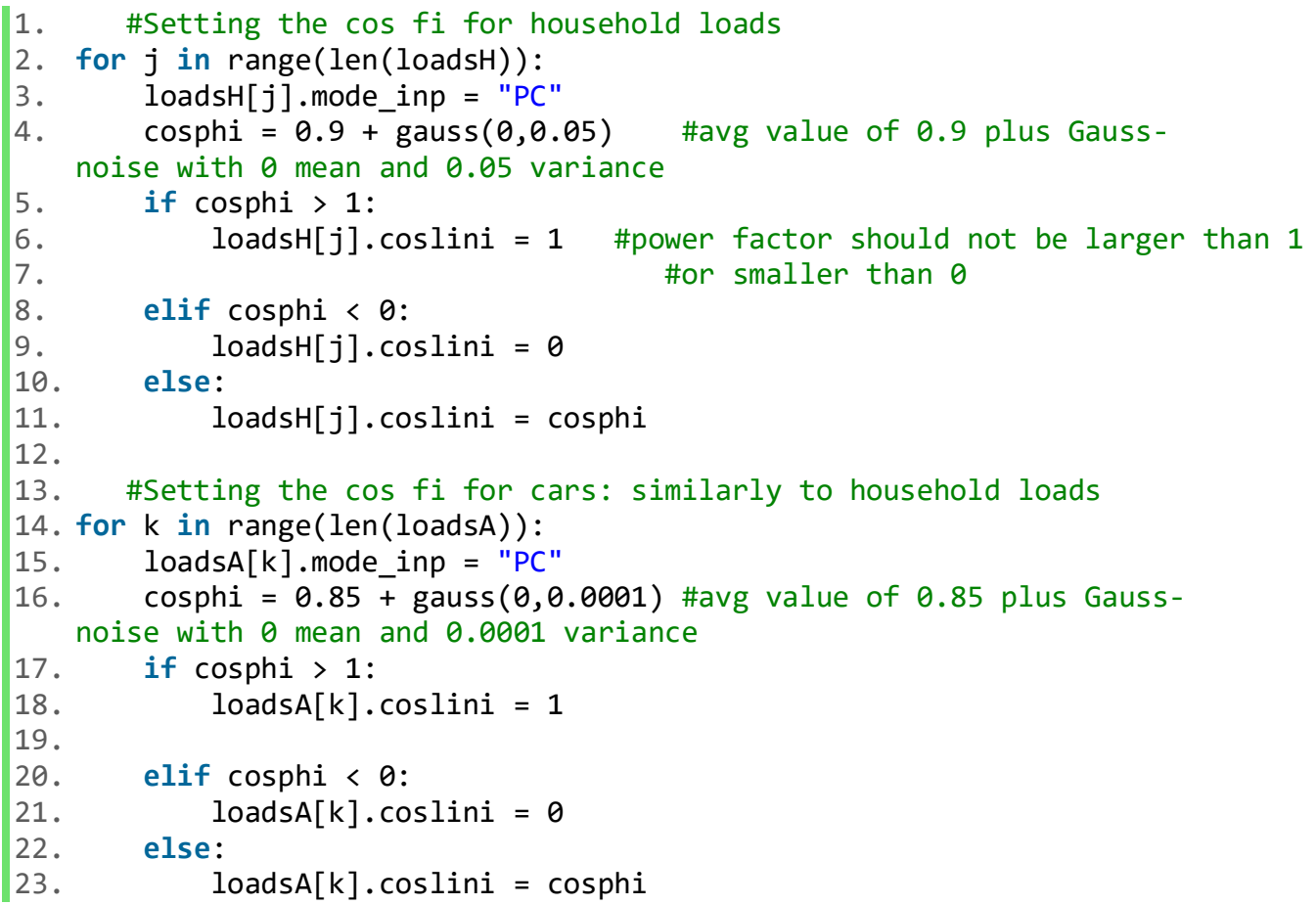




\subsection{Box and Whisker Plot}

We represented transformer loading, voltage and current profiles in box and whisker plot.

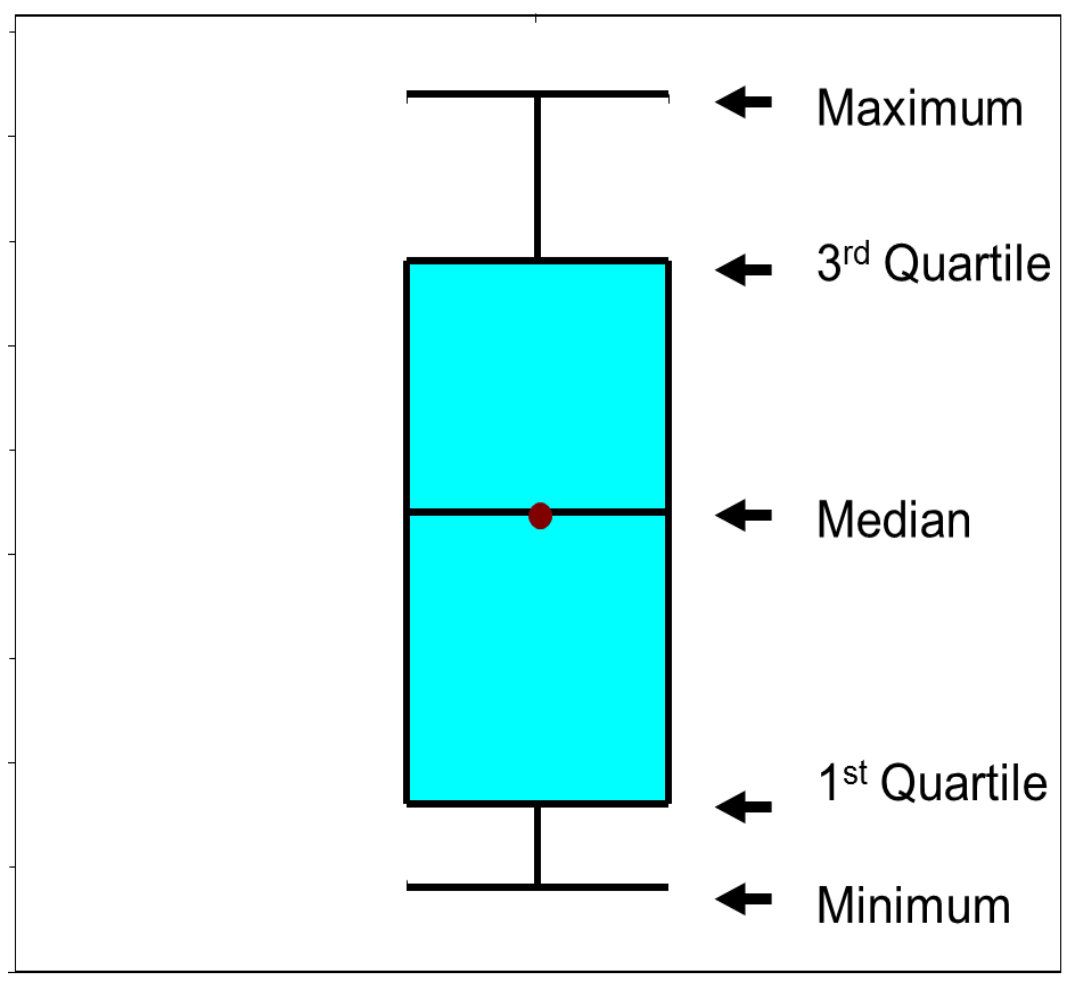

Figure 32: Box and Whisker Plot explanation

A box and whisker plot is a summarized graph containing the five numbers, minimum, lower quartile, median, upper quartile and maximum. While the box covers lower quartile, median, and upper quartile and whiskers are minimum and maximum values. These plots are very useful when large numbers of observations are involved and when two or more data sets are being compared. It is ideal for comparing distributions because the centre, spread and overall range are immediately apparent.

It gives a summary of a data set because each value describes a specific part of a data set: the median identifies the centre of a data set; the upper and lower quartiles span the middle half of a data set; and the highest and lowest observations provide additional information about the actual dispersion of the data. [41] 


\subsection{Effect of an electric car on the transformer}

After simulations, we have obtained the loading of the transformer with electric cars connected to the grid. Figure 33 shows the daily loading of the investigated transformer in which we can observe the very high peaks approximately 120-140\% from 18:00 to 23:00 hours. During this time duration, there is overloading in the transformer. When a large number of the electric car is connected to the grid, the overloading will increase and it can cause the damaging of transformer. Therefore, to maintain the transformer in safe operation the daily peaks must be less than the $100 \%$ of the maximum loading.

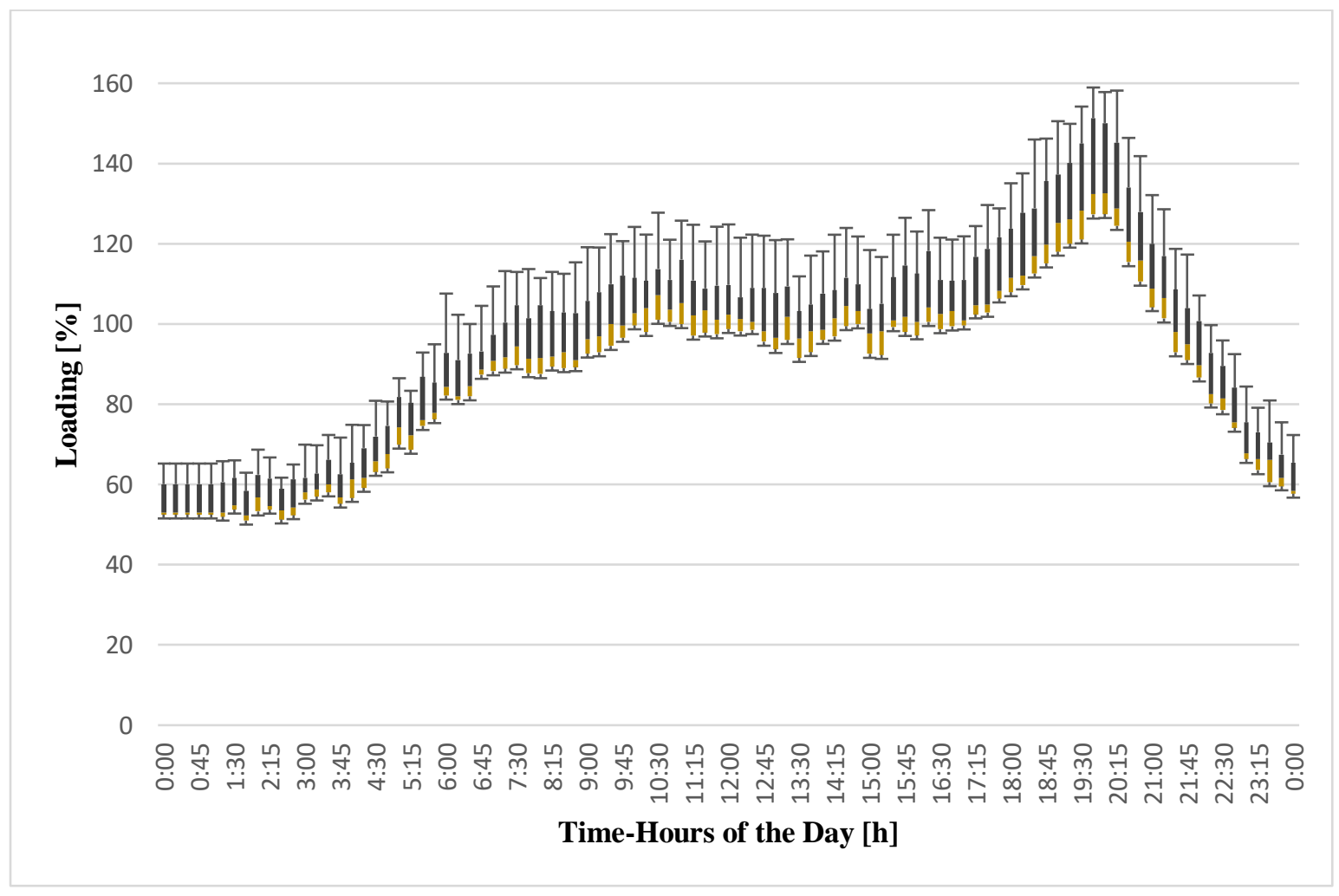

Figure 33: Daily loading of the transformer

To minimize this loading, we can either replace the transformer with a high rating or can charge electric vehicles during off-peak hours. Hence, the load profiles will be flattened and it reduces the daily expansion and contraction of the transformer which is also very useful for the transformer's life. We can implement many methods like Time of Use (ToU) pricing scheme, smart charging algorithm etc. to minimize the transformer loading by flattening the load profiles. 


\subsection{Voltage Profiles}

Besides the grid elements loading, the voltage drop is a big concern in low voltage distribution networks. It must be kept as small as possible and the voltage at the farthest points should be within limits and near 1 p.u.

Since bus bar trafo800 is the electrically most closed to the external grid, main grid in my case, and only a small voltage drops due to the transformer, therefore, this will not have large voltage drop. In Figure 34, we can see that all the voltages are between 0.96 pu to 1 pu at trafo800 bus bar, the maximum voltage is approximately $1 \mathrm{pu}$ and the minimum voltage is $0.96 \mathrm{pu}$.

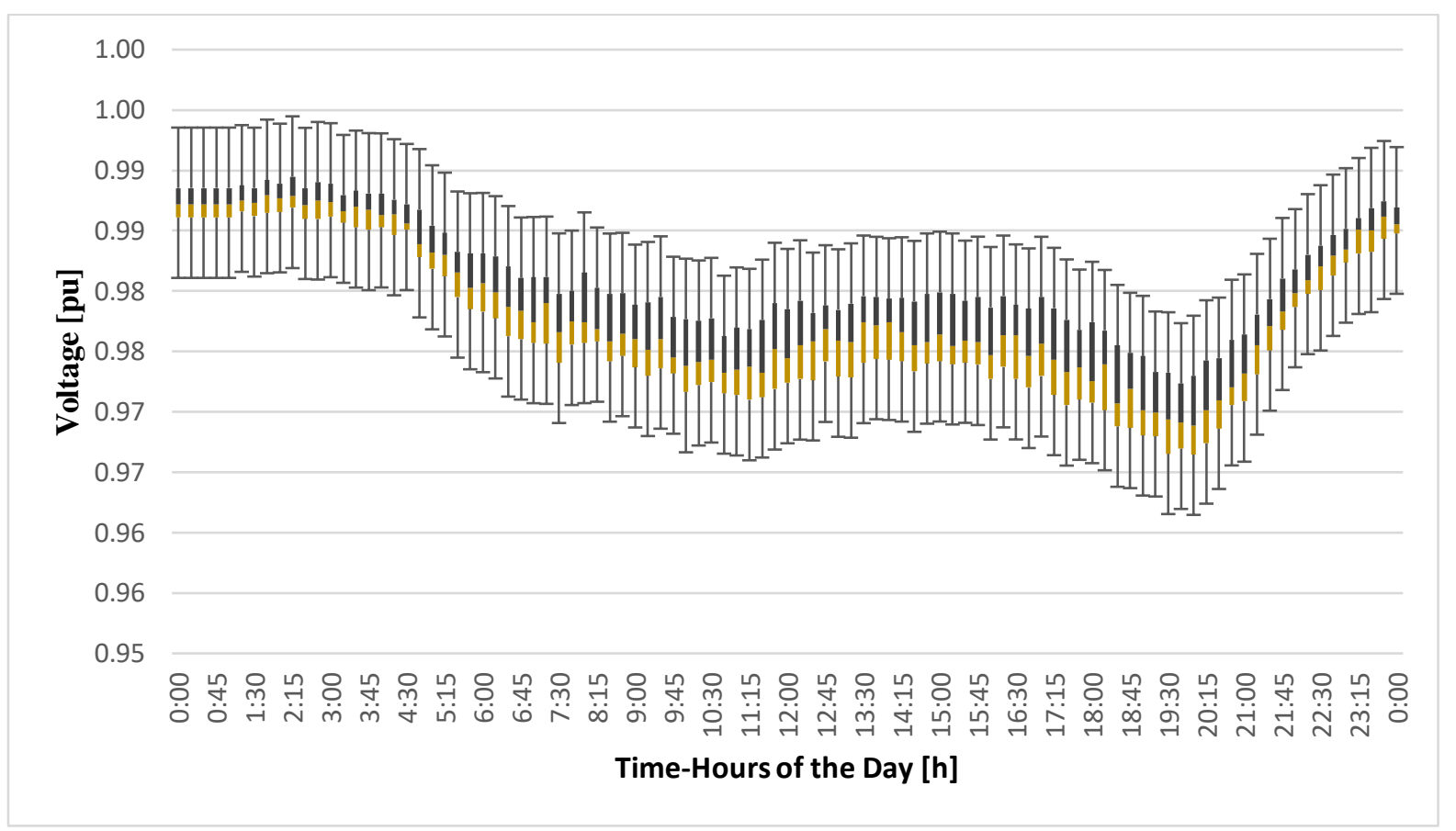

Figure 34: Voltage of the bus bar Trafo800

If there is no loading on the grid, there will be no voltage drop except for a small drop due to line resistance. When we move further at bus bar Node 2224 which is far away from the external grid and contains lots of household and electric car loads, the voltage drop at this bus bar is much higher than the bus bar Node 2225 because it is closer to the external grid and contains few loads. We can see how the voltage profiles look like in Figure 35 and Figure 36. At Node 2224, the range of maximum and minimum values of voltages are small as compared to the Node 2225 . The voltage drop at both bus bar is below $1 \mathrm{pu}$, therefore, it is not a big problem but it should be as low as possible. At Node 2224 and 2225, the minimum voltage is approximately $0.93 \mathrm{pu}$ and $0.96 \mathrm{pu}$ respectively and the maximum is somewhat lesser than 1 at both bus bar. 


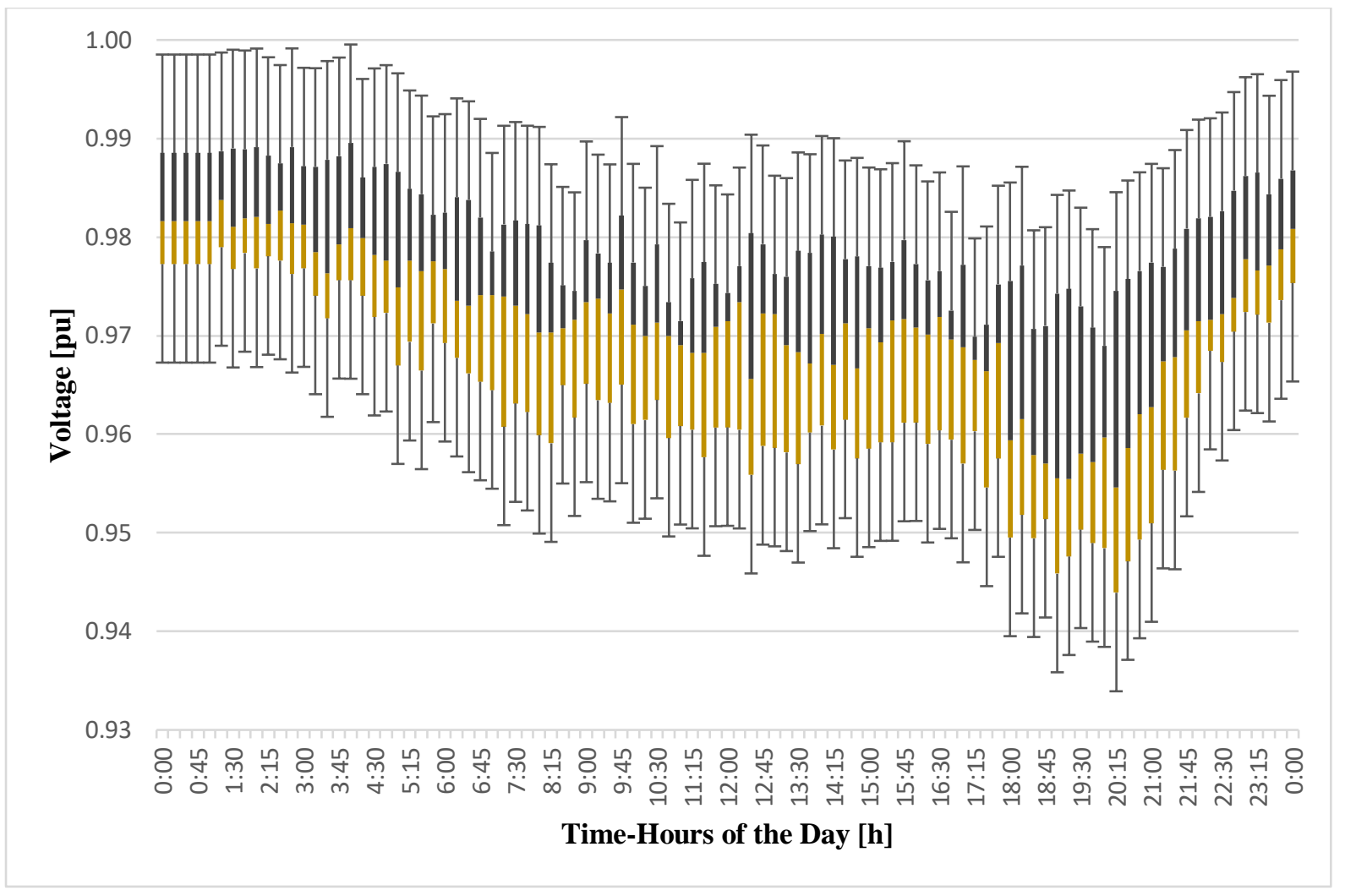

Figure 35: Voltage of the bus bar Node2224

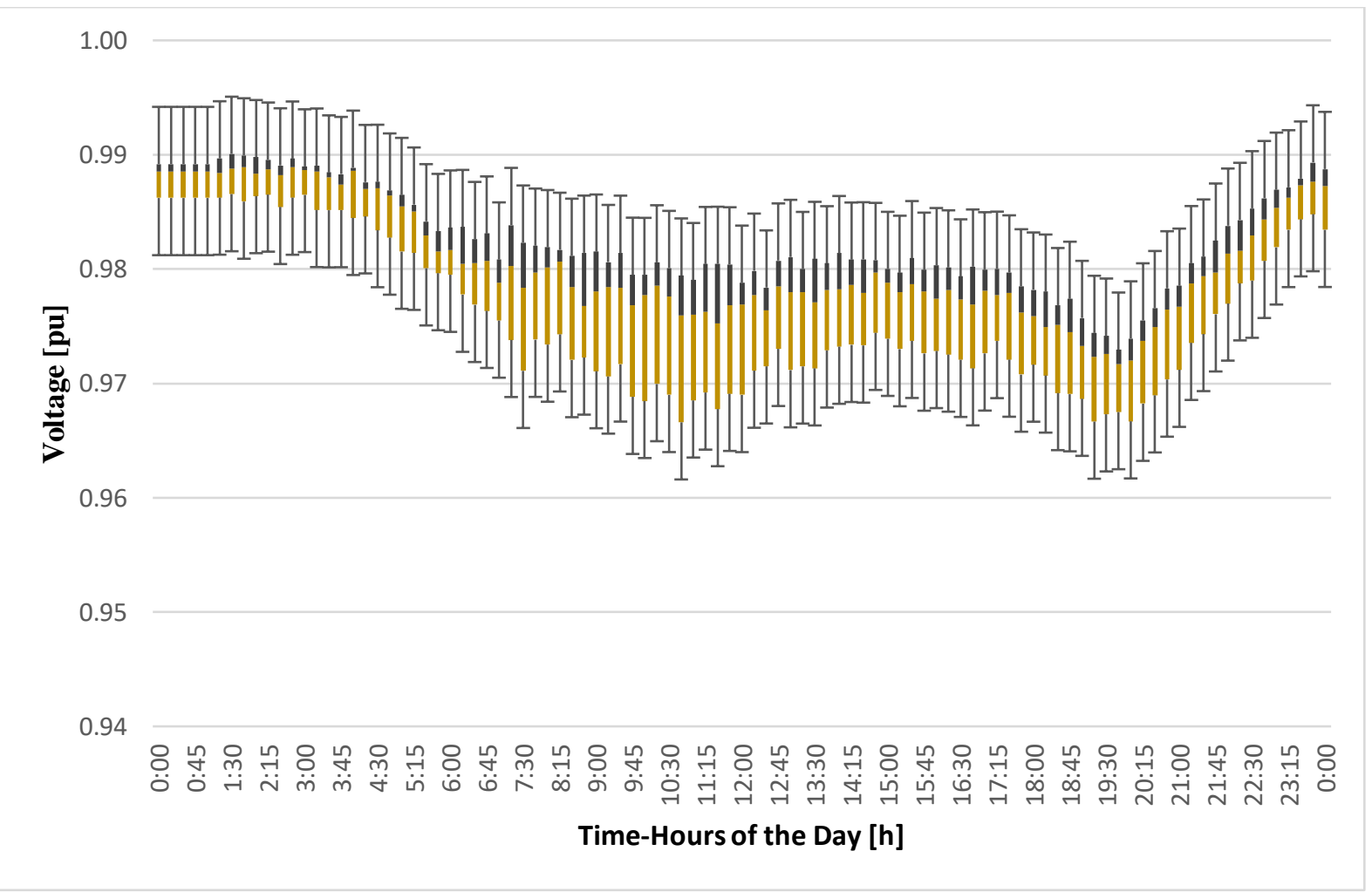

Figure 36: Voltage of the bus bar Node2225 
Similarly, Node 2231 and Node 2232 don't have any loads, therefore, there will be only a small voltage drop due to line resistance. As Node1543 has very few loads i.e. 3 household loads and one electric car load, therefore, the voltage drops at this bus bar at a specific time for example, at 21:15, is very low. In Figure 37 and Figure 38, the maximum voltage drop exceeds the $1 \mathrm{pu}$, which is not good for the grid elements.

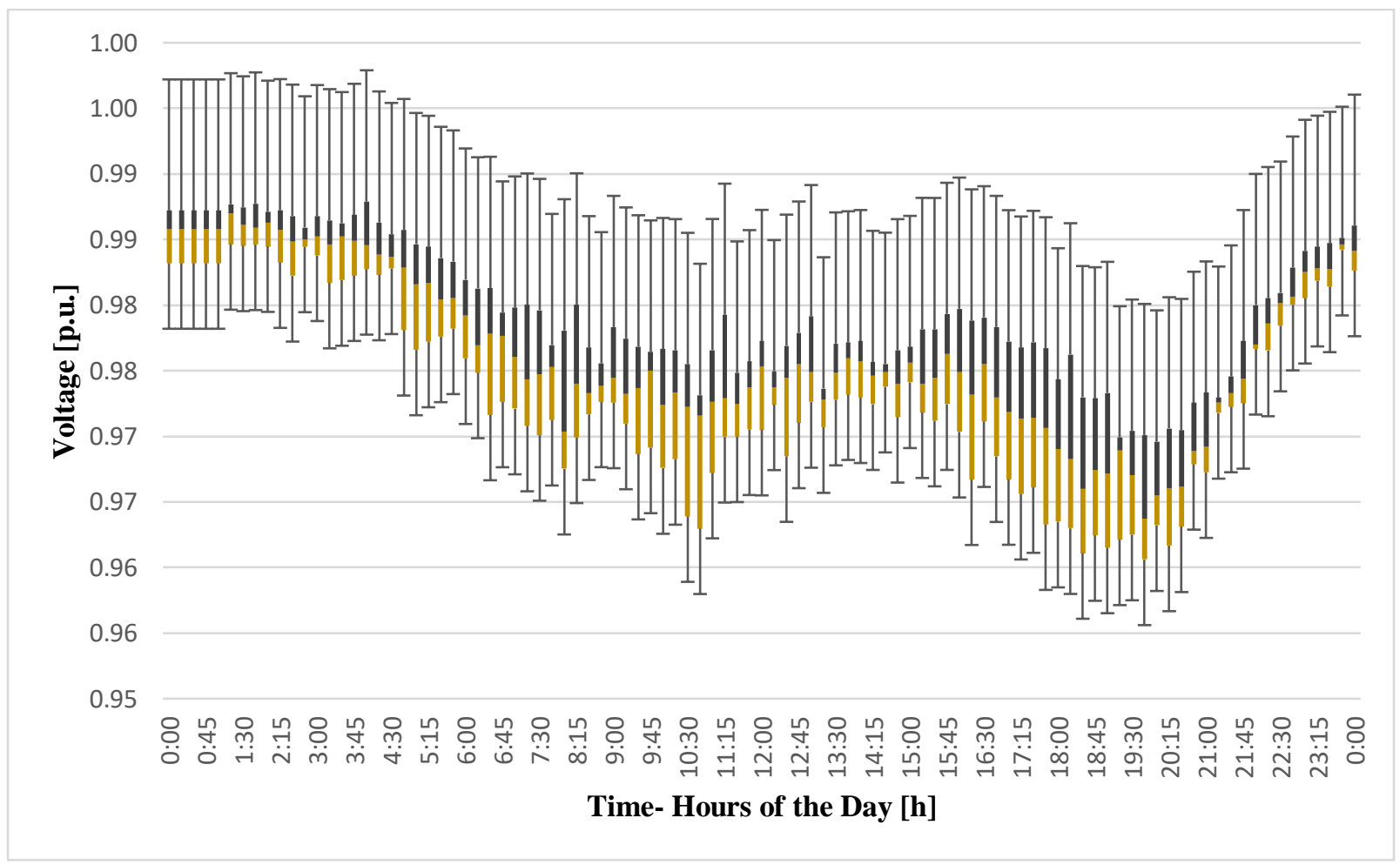

Figure 37: Voltage of the bus bar Node1543

By analysing all these voltage profiles, we observe that the average voltage drop at the different bus bar is in between $0.96 \mathrm{pu}$ to $0.99 \mathrm{pu}$. 


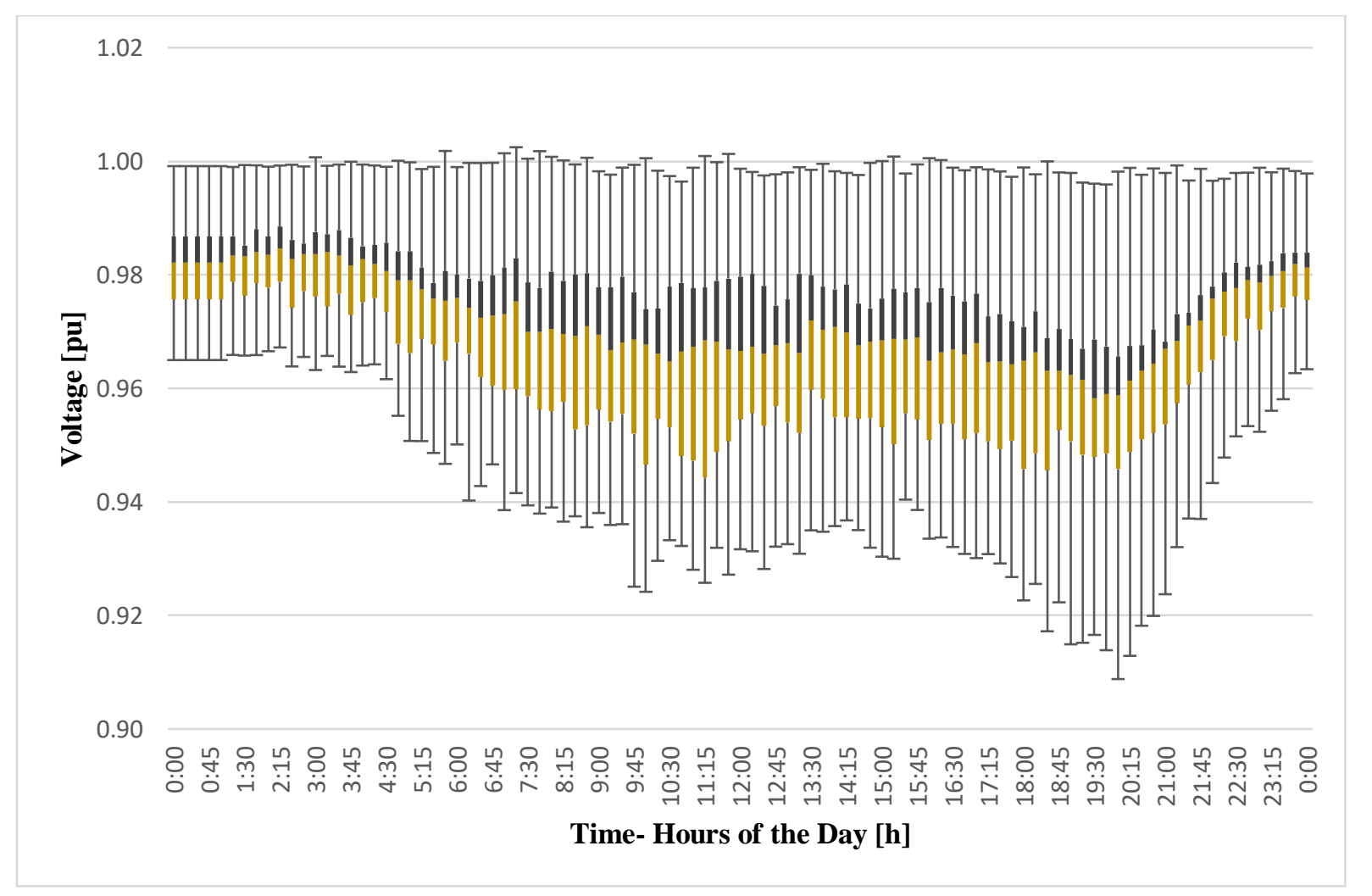

Figure 38: Voltage of the bus bar Node 2241

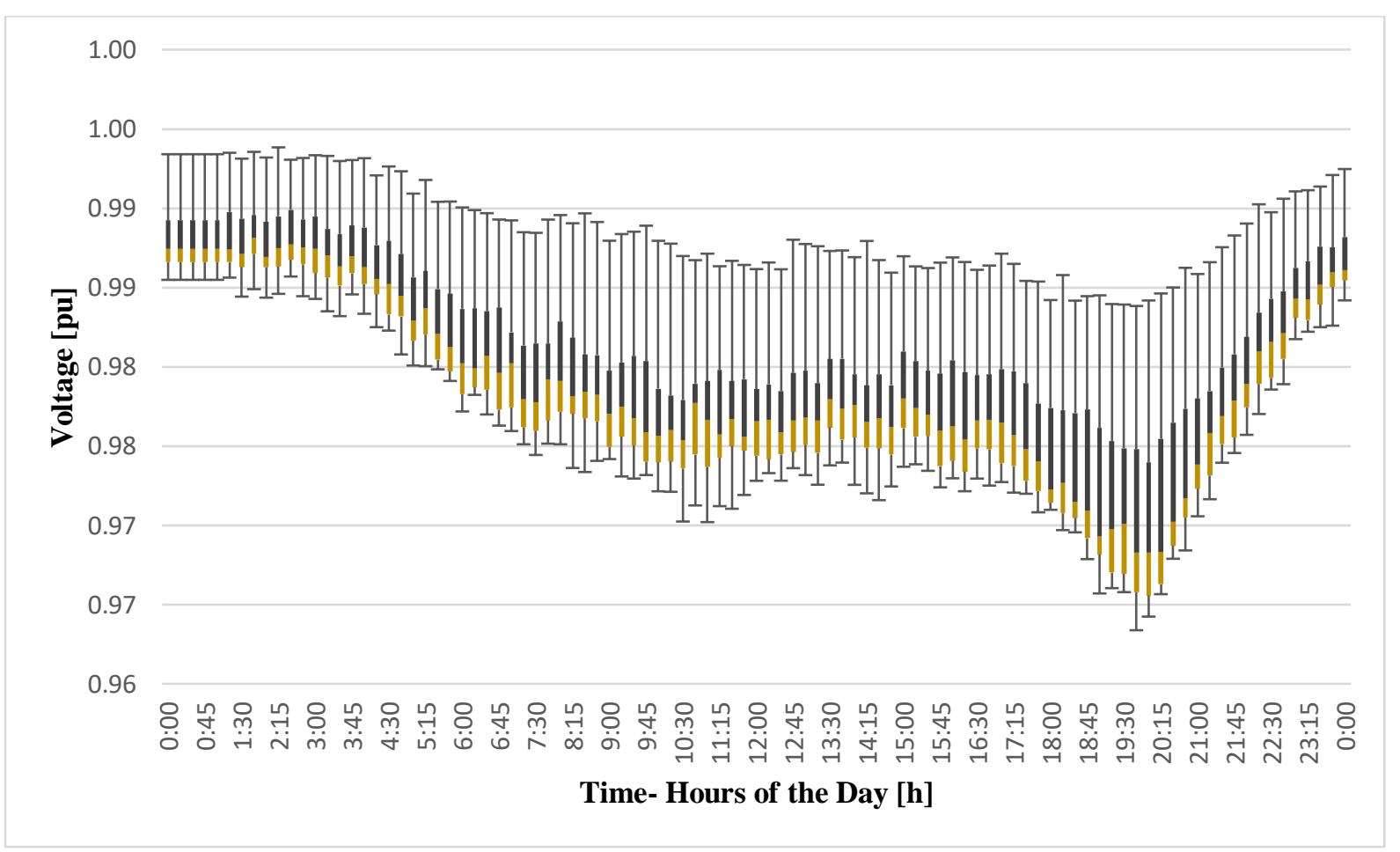

Figure 39: Voltage of the bus bar Node 2231 


\subsection{Current Profiles}

Knowing current through the branch is also important. Therefore, we analyzed the current through line 0 , line 16, line 27 and line 39 to know how much current is flowing in the respective branch. Branch containing line L0 has a large number of loads, hence it draws more current as compared to the branch which contains fewer loads.

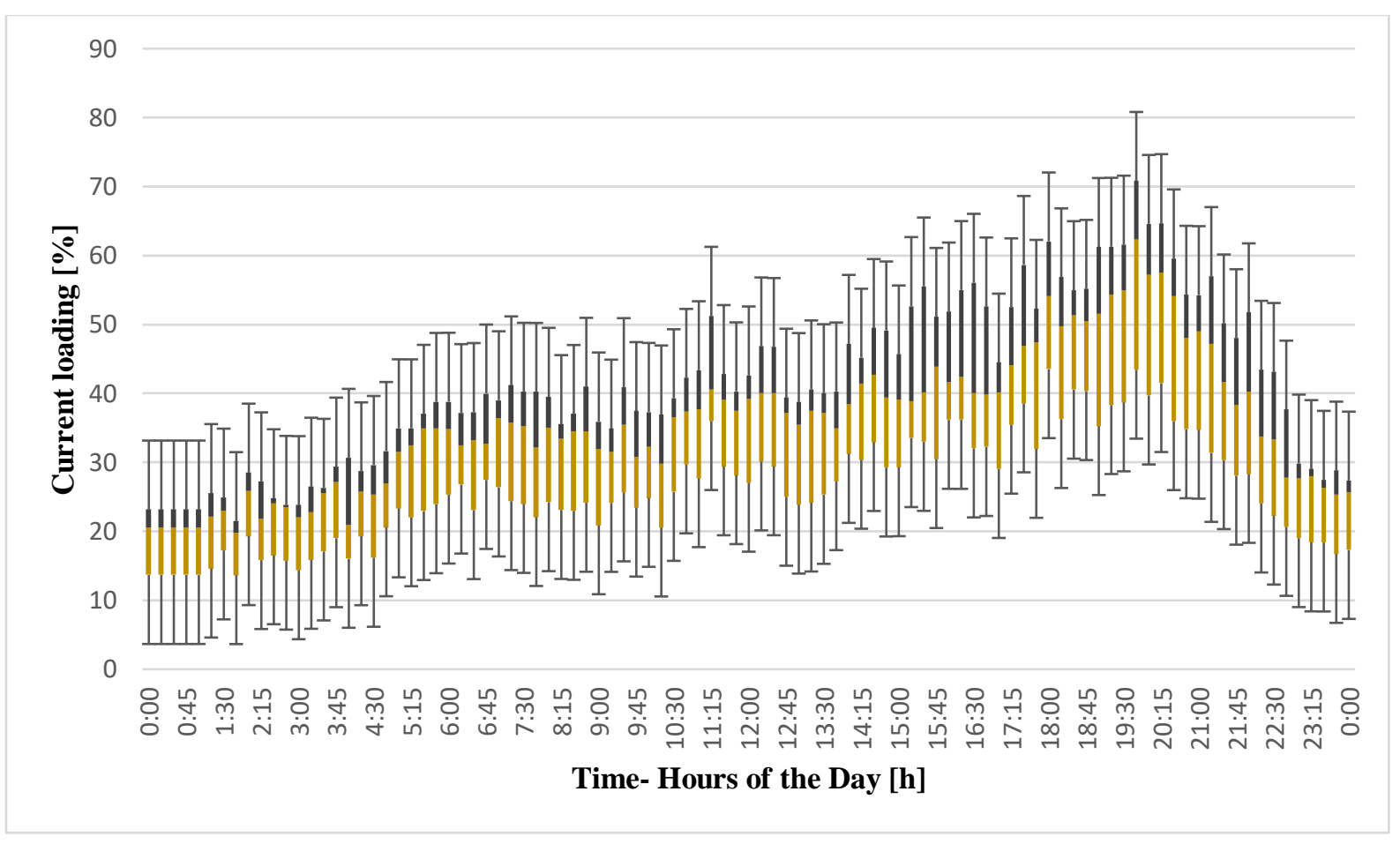

Figure 40: Current through line L16

We observe from Figure 40 that the current loading is below $60 \%$ in most of the cases. During peak periods, the current loading is a little bit higher. Since bus bar Node 2225 is closer to the grid with fewer loads and, larger cross-sections, smaller current flows through it.

On the other hand, the line L0 has larger loads and is further from the external grid, with smaller cross-sections and larger currents through it. In Figure 41, the current loading is maximum at a different time as compared to current loading in Figure 40. 


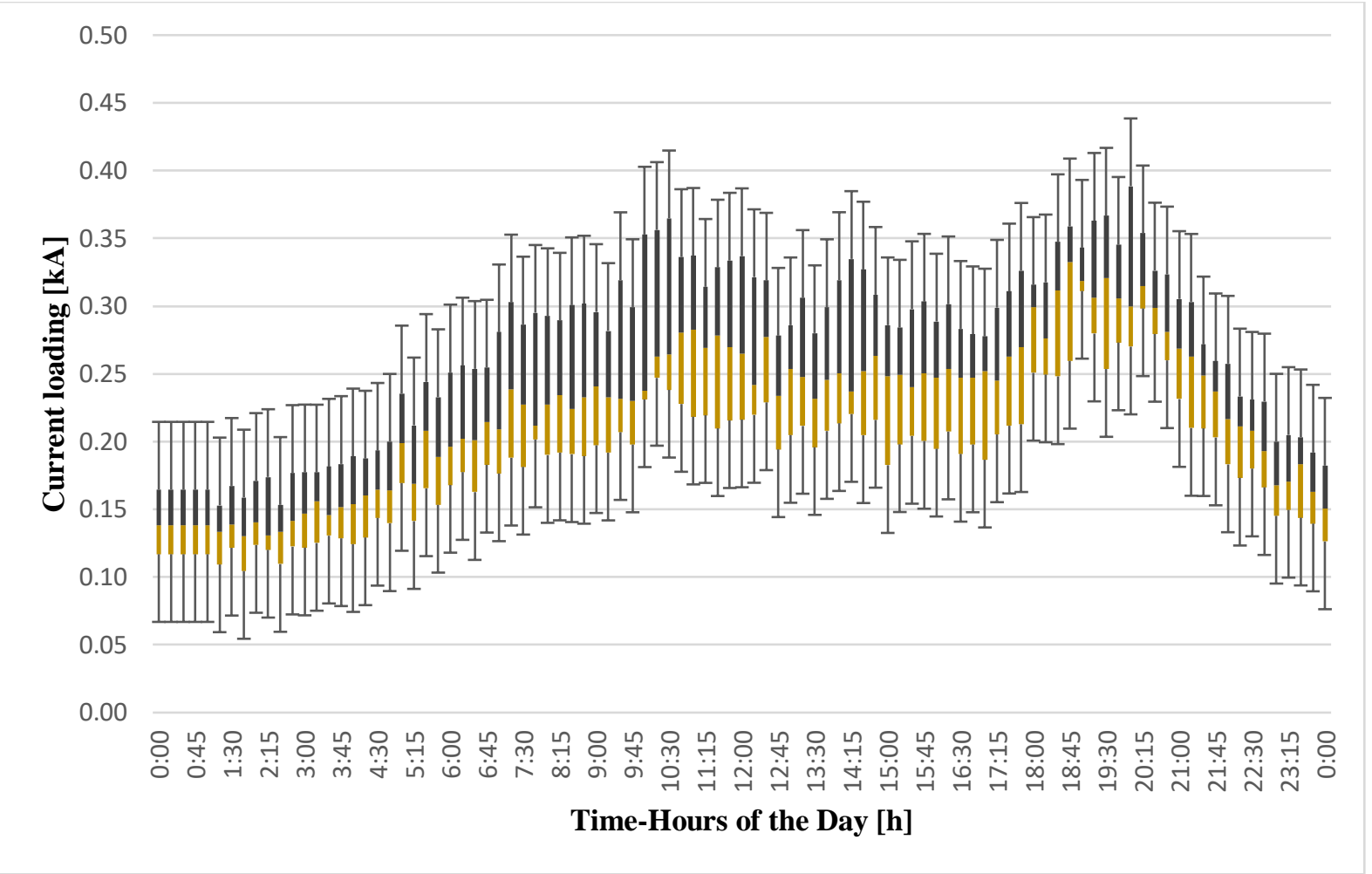

Figure 41: Current through line LO

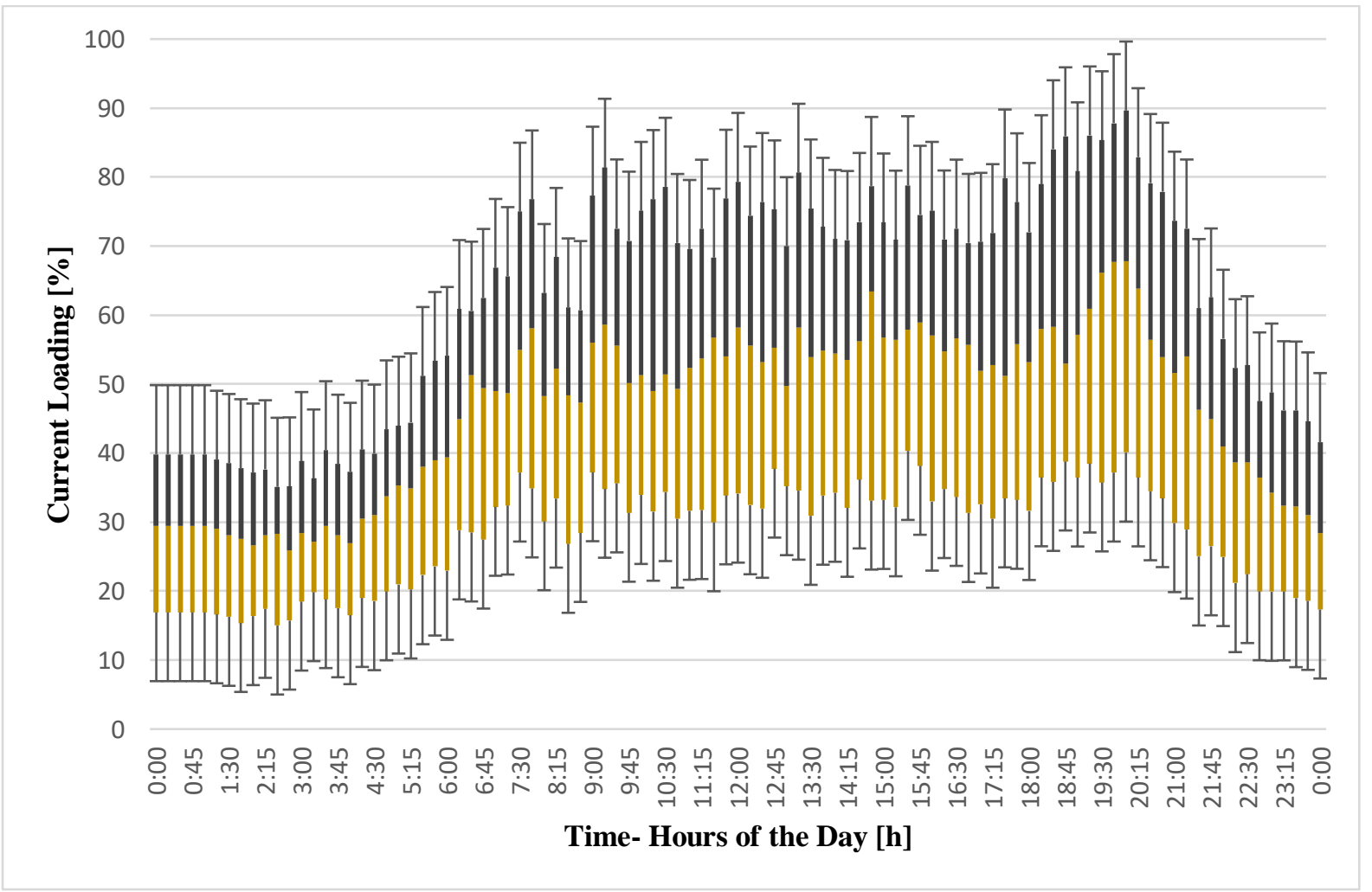

Figure 42: Current through line L27 


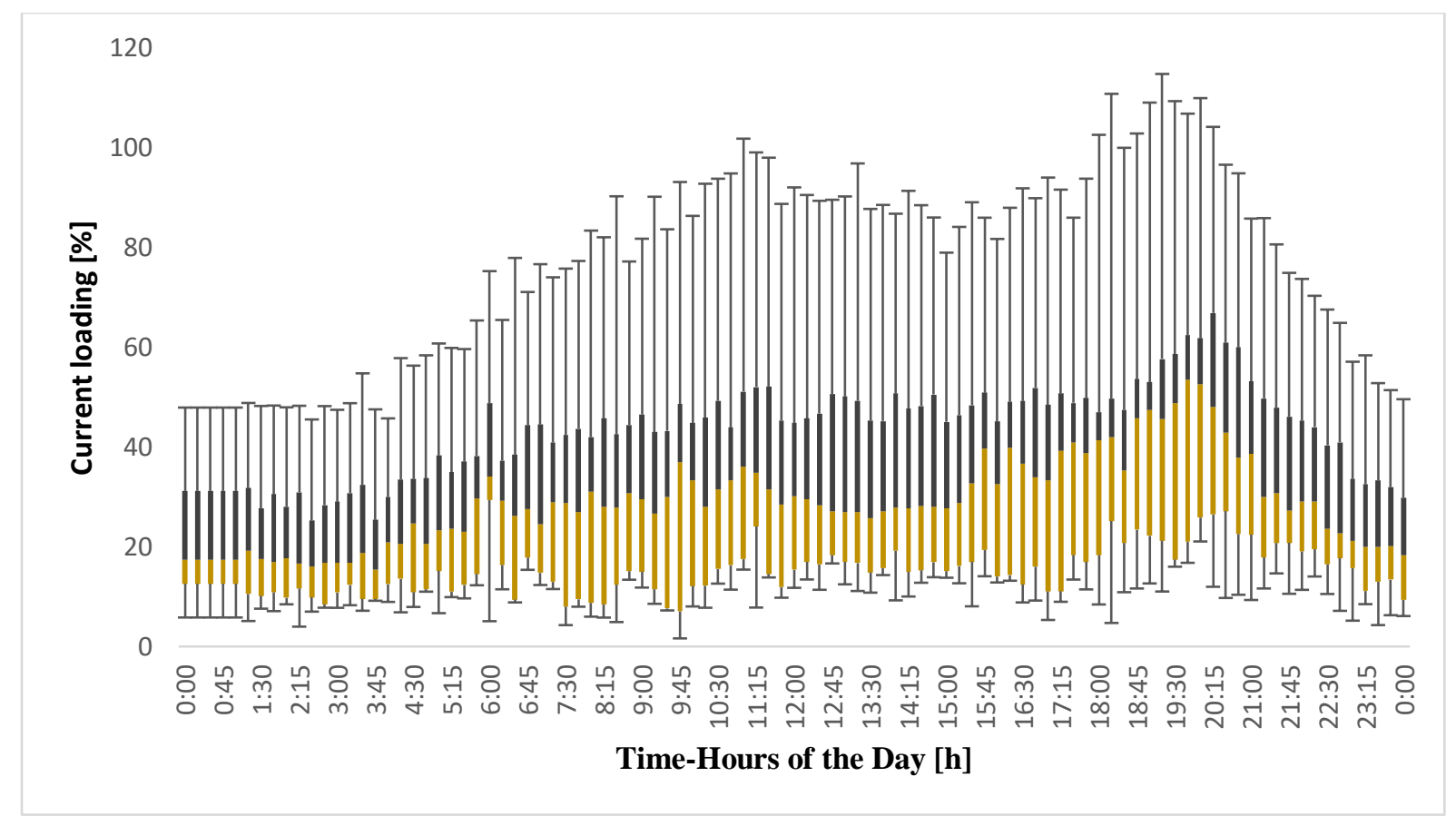

Figure 43: Current through line L39

By analysing all these current profiles, we observe that the average current loading through different branches is between $10 \%$ to $40 \%$. 


\section{Conclusions}

Presently, the number of electric cars is approximately 9000 in Hungary and it is going to increase very rapidly in the future. So, the question is how many electric cars can be supplied from the existing grid? A large deployment of electric cars in the present grid can cause heavy impacts such as transformer overloading, increased system peak demand and system losses. It can also cause power quality problems in the grid such as under-voltage conditions, and voltage and current profiles and harmonics. Therefore, we need to find out the possible solutions to mitigate these effects.

To know the effects of electric car charging on the low voltage grid, we did the simulations in the DigSilent powerfactory software by modelling a small grid and connecting some household loads and electric carloads. We run the unbalanced load flow and time sweep analysis to know the loading on the transformer and voltage and current profiles of the loads. We used python scripting to decrease the complexity in result analysis when there will be a huge number of electric cars in the future. After evaluating the result in box and whisker plot we found that the transformer used in our grid is overloaded i.e. most of the time it is greater than $100 \%$ of the maximum loading. The voltage drop along the farthest bus bar from the external grid is higher than the closest one. We observe that the average voltage drop at the different bus bar is in between $0.96 \mathrm{pu}$ to $0.99 \mathrm{pu}$. Also, the current loading is below $60 \%$ in most of the cases, however sometimes it is close to $100 \%$ of the current loading. To get a better view of the transformer loading and voltage problems, more simulations on a large number of electric cars can be run. 


\section{References}

[1] I. -. I. R. E. Agency, "Energy Transition," 2804 2019. [Online]. Available: https://www.irena.org/energytransition.

[2] "Energy consumption in Hungary," (C) WorldData.info, [Online]. Available: https://www.worlddata.info/europe/hungary/energy-consumption.php. [Accessed 28 April 2019].

[3] H. C. S. Office, "Transport," [Online]. Available: http://www.ksh.hu/docs/eng/xstadat/xstadat_long/h_odme001.html. [Accessed 28 April 2019].

[4] D. N. H. 2019, "Number of Electric Vehicles in Hungary Climbs Over 900," Daily News Hungary, 18 July 2016. [Online]. Available:

https://dailynewshungary.com/number-of-electric-vehicles-in-hungary-climbs-over900/. [Accessed 28 April 2019].

[5] TESLARATI, "History Lesson: The evolution of the electric car [Infographic]," 7 November 2017. [Online]. Available: https://www.teslarati.com/history-lessonevolution-electric-car-infographic/. [Accessed 11 May 2019].

[6] W. contributors, "History of the electric vehicle," Wikipedia, The Free Encyclopedia., [Online]. Available:

https://en.wikipedia.org/w/index.php?title=History_of_the_electric_vehicle\&oldid=89 2660442. [Accessed 11 May 2019].

[7] "How Do All-Electric Cars Work?," U.S. Department of Energy, [Online]. Available: https://afdc.energy.gov/vehicles/how-do-all-electric-cars-work. [Accessed 5 December 2018].

[8] B. University, "Comparison of Batteries".

[9] Wikipedia contributors, "State of charge," Wikipedia, The Free Encyclopedia., [Online]. Available:

https://en.wikipedia.org/w/index.php?title=State_of_charge\&oldid=870508701 .

[Accessed 11 May 2019].

[10] C. E. REVIEWS, "Battery Capacity And Depth Of Discharge (DOD)," [Online]. Available: https://www.cleanenergyreviews.info/blog/2014/9/9/lead-acid-deep-cyclebatteries. [Accessed 11 May 2019].

[11] Wordpress, "Depth of Discharge," [Online]. Available: https://energymag.net/doddepth-of-discharge/. [Accessed 11 May 2019].

[12] A. F. D. Center, "Batteries for Hybrid and Plug-In Electric Vehicles," AFDC, [Online]. Available: https://afdc.energy.gov/vehicles/electric_basics_ev.html. [Accessed 15 May 2019]. 
[13] G. E. C. Alliance, "Charging," [Online]. Available:

https://www.greenenergyconsumers.org/drivegreen/charging\#levels. [Accessed 29 April 2019].

[14] D. Nicol, "A Guide to Electric Vehicle Charging," PHOENIX CONTACT, [Online]. Available: https://blog.phoenixcontact.com/marketing-gb/a-guide-to-electric-vehiclecharging/. [Accessed 11 May 2019].

[15] I. E. Agency, "Electric car share in the SDS," IEA 2019, [Online]. Available: https://www.iea.org/tcep/transport/evs/. [Accessed 28 April 2019].

[16] B. B. Journal, "Hungarian government could add 50,000 electric cars to road networks by 2020.," 17 May 2016. [Online]. Available: https://bbj.hu/politics/hungariangovernment-could-add-50000-electric-cars-to-road-networks-by-2020_116166. [Accessed 28 April 2019].

[17] P. G. a. P. B. Ádám Osztovits, "Electric cars: A market outlook," [Online]. Available: www.pwc.com/hu. [Accessed 30 April 2019].

[18] T. D. Sun, "Sales of Electric Cars in Hungary Multiplied By Five," 9 March 2019. [Online]. Available: http://www.debrecensun.hu/eco/2018/03/09/sales-of-electric-carsin-hungary-multiplied-by-five/. [Accessed 29 April 2019].

[19] E. A. M. Association, "Passenger Car Fleet by Fuel Type," ACEA, 29 April 2019. [Online]. Available: https://www.acea.be/statistics/article/Passenger-Car-Fleet-byFuel-Type.

[20] Statista, "Number of passenger cars per 1,000 inhabitants in Europe (EU-28) between 1990 and 2016," 29 April 2019. [Online]. Available:

https://www.statista.com/statistics/452238/europe-eu-28-number-of-cars-per-1000inhabitants/.

[21] ACEA, "Vehicles Per Capita, by Country," 29 April 2019. [Online]. Available: https://www.acea.be/statistics/tag/category/vehicles-per-capita-by-country.

[22] E. A. M. Association, "Share of Alternative Fuel Vehicles per Vehicle Segment," ACEA, 29 April 2019. [Online]. Available:

https://www.acea.be/statistics/tag/category/share-of-alternative-fuel-vehicles-pervehicle-segment.

[23] W. E. Forum, "Japan now has more electric charging points than petrol stations," WEF, 09 May 2016. [Online]. Available: https://www.weforum.org/agenda/2016/05/japan-now-has-more-electric-chargingpoints-than-petrol-stations/. [Accessed 29 April 2019].

[24] INSIDEEVs, "76\% Of Charging Points In Europe Are Concentrated In Just 4 Countries," 25 Oct 2018. [Online]. Available: https://insideevs.com/news/340641/76of-charging-points-in-europe-are-concentrated-in-just-4-countries/. [Accessed 29 April 2019]. 
[25] ACEA, "Electric cars: unrealistic $\mathrm{CO} 2$ targets proposed by EU Parliament ignore lack of charging points," 5 July 2018. [Online]. Available: https://www.acea.be/pressreleases/article/electric-cars-unrealistic-co2-targets-proposed-by-eu-parliament-ignorelack. [Accessed 29 April 2019].

[26] s. 2019, "Number of electric vehicle charging stations in Hungary from 2013 to 2018, by type," [Online]. Available: https://www.statista.com/statistics/933078/number-ofelectric-vehicle-charging-stations-in-hungary/. [Accessed 29 April 2019].

[27] B. B. Journal, "Budapest to see more e-car charging stations," 13 Dec 2019. [Online]. Available: https://bbj.hu/budapest/budapest-to-see-more-e-car-chargingstations_126184. [Accessed 29 April 2019].

[28] E. European Alternative Fuels Observatory, "Charging Infrastructure," [Online]. Available: https://www.eafo.eu/countries/europeanunion/23640/infrastructure/electricity/compare. [Accessed 29 April 2019].

[29] K. I. S. a. L. P. Csaba Farkas, "Impact assessment of electric vehicle charging on a LV distribution system," in 3rd International Youth Conference on Energetics (IYCE), Leiria, 2011.

[30] (. M. I. A. S. S. (. I. ANAMIKA DUBEY, "Electric Vehicle Charging on Residential Distribution Systems: Impacts and Mitigations," IEEE Access, vol. 3, pp. 1871 - 1893, 2015.

[31] GENI, "National Energy Grid Hungary," Global Energy Network Institute, [Online]. Available:

http://www.geni.org/globalenergy/library/national_energy_grid/hungary/index.shtml. [Accessed 29 April 2019].

[32] MAVIR, "Hungarian electricity network," MAVIR, [Online]. Available: http://mavir.hu/web/mavir-en. [Accessed 14 May 2019].

[33] GENI, "Electricity Report on Hungary," [Online]. Available: https://www.geni.org/globalenergy/library/national_energy_grid/hungary/09-hun.htm. [Accessed 29 April 2019].

[34] Wikipedia contributors, "Electrical grid," Wikipedia, The Free Encyclopedia., [Online]. Available:

https://en.wikipedia.org/w/index.php?title=Electrical_grid\&oldid=888115070. [Accessed 29 April 2019].

[35] T. Services, "Electricity consumption in Hungary at record high," 22 Jan 2019. [Online]. Available: https://www.tscnet.eu/electricity-consumption-hungary-recordhigh/. [Accessed 29 April 2019].

[36] I. E. Agency, "Total Final Consumption (TFC) by source," [Online]. Available: https://www.iea.org/statistics/?country=HUNGARY\&year=2016\&category=Energy\% 
20consumption \&indicator $=$ TFCbySource $\&$ mode $=$ chart $\&$ dataTable=BALANCES . [Accessed 29 April 2019].

[37] P. G. a. E. Company, "Electric Vehicle (EV) rate plans," [Online]. Available: https://www.pge.com/en_US/residential/rate-plans/rate-plan-options/electric-vehiclebase-plan/electric-vehicle-base-plan.page. [Accessed 11 May 2019].

[38] Enervalis, "The challenge," [Online]. Available: https://www.enervalis.com/smart-evcharging/. [Accessed 11 May 2019].

[39] S. Z. a. H. K. Tóth István, "Gellérthegy - Lágymányos 0,4kV-os," PD-TEAM MÉRNÖKI IRODA KFT, Budapest, 2001.

[40] C. D. L. a. J. L. R. Torres, "Python Scripting for DIgSILENT PowerFactory," in Advanced Smart Grid Functionalities Based on PowerFactory, Green Energy and Technology, Delft, Springer International Publishing AG 2018, 2018, pp. 19-25.

[41] Statistics Canada, "Constructing box and whisker plots," Statistics Canada, [Online]. Available: https://www150.statcan.gc.ca/n1/edu/power-pouvoir/ch12/5214889eng.htm. [Accessed 10 May 2019].

[42] "Electricity consumption in Hungary at record high," TSCNET Services GmbH, [Online]. Available: https://www.tscnet.eu/electricity-consumption-hungary-recordhigh/. [Accessed 14 April 2019].

[43] L. P. a. C. Farkas, "Impacts of Electric Vehicle Chargers on the Power Grid," in International Youth Conference on Energy (IYCE), IEEE, Pisa, 2015.

[44] F. D. a. A. V.-M. E. Vega-Fuentes, "Electric vehicle grid integration analysis in low voltage networks," in International Conference on Modern Electrical Power Engineering (ICMEPE), Las Palmas, 2016.

[45] H. R. A. A. a. C. F. Morsy Nour, "Impacts of Plug-In Electric Vehicles Charging on Low Voltage Distribution Network," in International Conference on Innovative Trends in Computer Engineering (ITCE), Aswan, 2018. 